UDK 902

ISSN 1330-0644

VOL 35/2018.

ZAGREB, 2018.

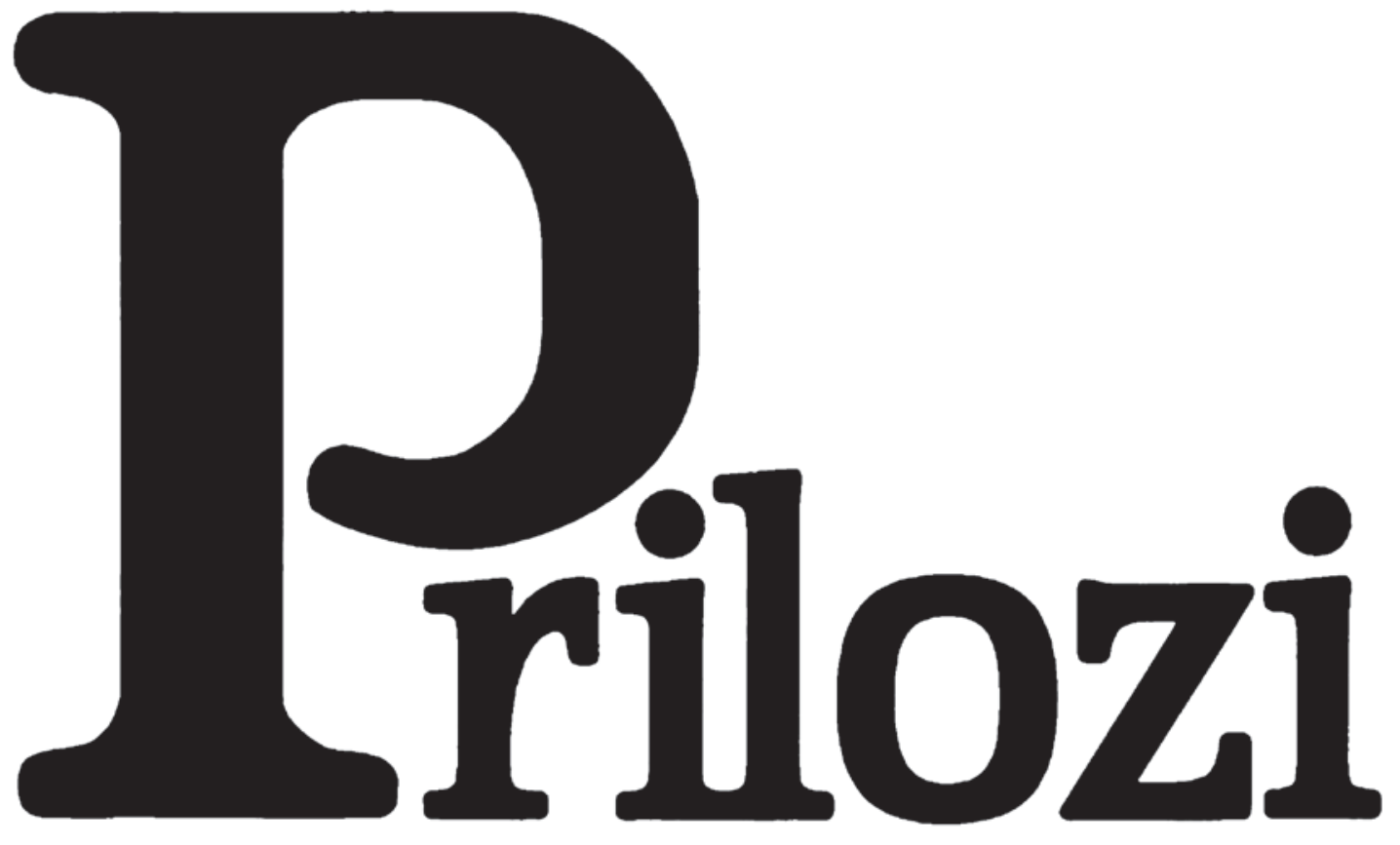

Instituta za arheologiju u Zagrebu 
Pril. Inst. arheol. Zagrebu, 35/2018

Str./Pages 1-328, Zagreb, 2018.
Ovaj rad licenciran je pod Creative Commons Attribution By 4.0 međunarodnom licencom / This work is licenced under a Creative Commons Attribution By 4.0 International Licence
Izdavač/Publisher

INSTITUT ZA ARHEOLOGIJU

INSTITUTE OF ARCHAEOLOGY

Adresa uredništva/Address of the editor's office Institut za arheologiju/Institute of archaeology HR-10000 Zagreb, Ulica Ljudevita Gaja 32

Hrvatska/Croatia

Telefon/Phone ++385/(0)1 6150250

Fax $++385(0) 16055806$

e-mail: urednistvo.prilozi@iarh.hr

http://www.iarh.hr

Glavni i odgovorni urednik/Editor in chief

Marko DIZDAR

Uredništvo/Editorial board

Marko DIZDAR, Snježana KARAVANIĆ, Viktória KISS (Budapest, HUN) (prapovijest/Prehistory), Goranka LIPOVAC VRKLJAN (antika/Antiquities), Tajana SEKELJ IVANČAN, Katarina Katja PREDOVNIK (Ljubljana, SLO), Natascha MEHLER (Wien, AUT), Juraj BELAJ, Tatjana TKALČEC (kasni srednji vijek i novi vijek/Late Middle Ages and Modern era), Predrag NOVAKOVIĆ (Ljubljana, SLO) (metodologija/Methodology)

Izdavački savjet/Editorial advisory board

Dunja GLOGOVIĆ (Zagreb), Ivor KARAVANIĆ (Zagreb), Laszlo KÓVACS (Budapest, HUN),

Kornelija MINICHREITER (Zagreb), Mladen RADIĆ (Osijek), Aleksandar RUTTKAY (Nitra, SK), Ivančica SCHRUNK (Minneapolis, USA), Željko TOMIČIĆ (Zagreb), Ante UGLEŠIĆ (Zadar)

Prijevod na engleski/English translation

Edward BOSNAR, Kristina BRKIĆ, Nikola CESARIK, Ivan DRNIĆ, Ana ĐUKIĆ, Nataša ĐURĐEVIĆ, Emanuele FALCONE, Stašo FORENBAHER, Marija KOSTIĆ, Danijel LONČAR, Marko MARAS, Tina MILAVEC, David ŠTRMELJ

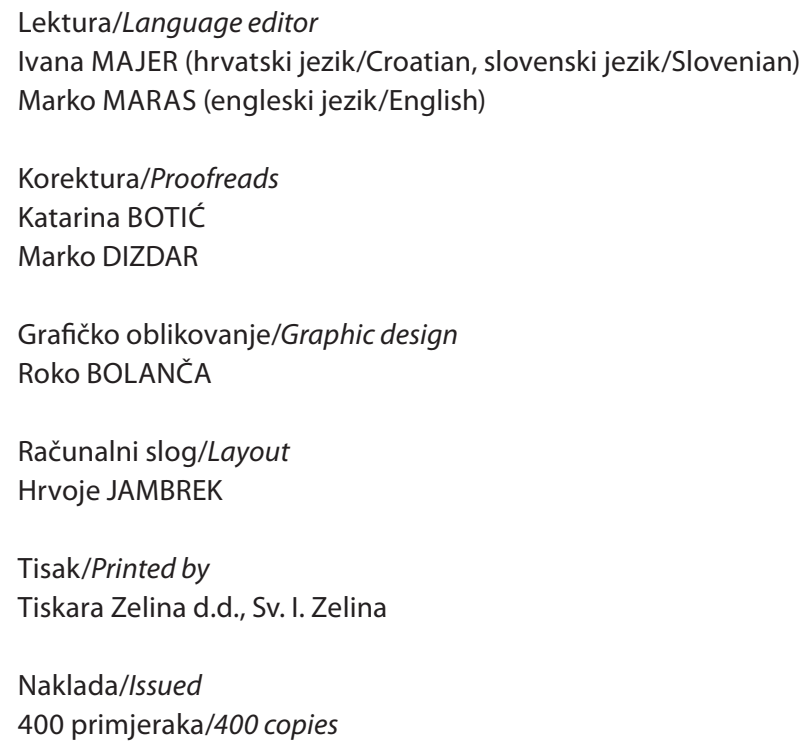

Prilozi Instituta za arheologiju u Zagrebu uključeni su u sljedeće indekse/ Prilozi Instituta za arheologiju u Zagrebu are included in following indices:

DYABOLA - Sachkatalog der Bibliothek - Römisch-Germanische Kommission des Deutschen Archaeologischen Instituts, Frankfurt a. Main

Clarivate Analytics services - Emerging Sources Citation Index

CNRS/INIST - Centre National de la Recherche Scientifi que/L'Institut de I'Information Scientifi que et Technique, Vandoeuvre-lès-Nancy

EBSCO - Information servises, Ipswich

ERIH - European Reference Index for the Humanities, European Science Fundation, Strasbourg SciVerse Scopus - Elsevier, Amsterdam 
Pril. Inst. arheol. Zagrebu, 35/2018

Str./Pages 1-328, Zagreb, 2018.

Sadržaj

\section{Izvorni znanstveni radovi}

DARIO VUJEVIĆ STIPAN DILBER

Izvor - špilja Ričina u Buškome jezeru. Prvi tragovi paleolitika na području zapadne Hercegovine

IVAN DRNIĆ

KONSTANTINOS P. TRIMMIS

ALEXANDRA HALE

RICHARD MADGWICK

KELLY REED

ANTONELA BARBIR

MARIN MAĐERIĆ

Assemblages from Marginal Spaces: The results of the excavations in Mala (Nova) Pećina near Muć and the Neolithic of Dalmatinska Zagora

HRVOJE KALAFATIĆ

BARTUL ŠILJEG

KRUGOVI PARNJACI: novi uvidi u neolitičke

obrasce naseljavanja

113 STAŠO FORENBAHER

Ljubljana i Cetina: lončarski stilovi 3. tisućljeća prije Krista na prostoru istočnoga Jadrana

ZVONKO BOJČIĆ

DARIA LOŽNJAK DIZDAR

TOMISLAV HRŠAK

Nove spoznaje o kronologiji groblja Batina -

Sredno na početku starijega željeznog doba

KORNELIJA A. GIUNIO

NIKOLA CESARIK

DAVID ŠTRMELJ

Šest baza počasnih statua iz Jadera

\section{Contents}

\section{Original scientific papers}

DARIO VUJEVIĆ
STIPAN DILBER

The Ričina spring cave in Buško Jezero. The first traces of the Palaeolithic in the western Herzegovina region

IVAN DRNIĆ

KONSTANTINOS P. TRIMMIS

ALEXANDRA HALE

RICHARD MADGWICK

KELLY REED

ANTONELA BARBIR

MARIN MAĐERIĆ

Nalazi iz marginalnih prostora: Rezultati istraživanja Male (Nove) pećine pokraj Muća i neolitik

Dalmatinske zagore

HRVOJE KALAFATIĆ

BARTUL ŠILJEG

TWIN CIRCLES: new insights in the Neolithic settlment pattern

\section{STAŠO FORENBAHER}

Ljubljana and Cetina: Pottery Styles of the Third Millennium BC in the Eastern Adriatic

\section{ZVONKO BOJČIĆ \\ DARIA LOŽNJAK DIZDAR}

TOMISLAV HRŠAK

New knowledge about the chronology of The Batina - Sredno cemetery at the beginning of the Early Iron Age

KORNELIJA A. GIUNIO

NIKOLA CESARIK

DAVID ŠTRMELJ

Six Honorary Statue Bases from Iader 
219 MIRKO RAŠIĆ

JOSIPA BARAKA PERICA

Starokršćanski kompleks u Docima kod Vitine: rezultati revizijskih arheoloških istraživanja

239 TINA MILAVEC

The elusive early medieval glass: remarks on vessels from the Nin - Ždrijac cemetery, Croatia

\section{Pregledni rad}

251 ANA ĐUKIĆ

Prapovijesne glačane kamene izrađevine sjeverozapadne Hrvatske

291 MARIN ZANINOVIĆ

Kako sam ustanovio postojanje grčkoga katastra (chora) u Starigradskom polju

299 ANA AZINOVIĆ BEBEK

Novovjekovna arheologija u Hrvatskoj - problemi metodologije, terminologije i imena
MIRKO RAŠIĆ

JOSIPA BARAKA PERICA

The early Christian complex in Doci, Vitina: the results of the revised archaeological research

\section{TINA MILAVEC}

Izmikajoče se zgodnjesrednjeveško steklo: komentar k posodam z grobišča Nin-Ždrijac, Hrvaška

\section{Report}

\author{
ANA ĐUKIĆ \\ Prehistoric polished stone implements from \\ northwestern Croatia
}

MARIN ZANINOVIĆ

How I identified a Greek cadastre (chora) on the Stari Grad Plain

ANA AZINOVIĆ BEBEK

Early Modern Archaeology in Croatia - Problems of Methodology, Terminology and Nomenclature 


\title{
Nove spoznaje o kronologiji groblja Batina - Sredno \\ na početku starijega željeznog doba
}

\section{New knowledge about the chronology of The Batina - Sredno cemetery \\ at the beginning of the Early Iron Age}

Izvorni znanstveni rad

Prapovijesna arheologija

Original scientific paper

Prehistoric archaeology

UDK/UDC 903.5(497.5 Draž)"638"

Primljeno/Received: 15. 01. 2018.

Prihvaćeno/Accepted: 12. 06. 2018.

\author{
ZVONKO BOJČıĆ \\ Arheološki muzej Osijek \\ Trg Sv. Trojstva 2 \\ HR-31000 Osijek \\ zvonko.bojcic@mso.hr
Institut za arheologiju
Ulica Ljudevita Gaja 32
HR-10000 Zagreb
dldizdar@iarh.hr \\ DARIA LOŽNJAK DIZDAR \\ TOMISLAV HRŠAK \\ Arheološki muzej Osijek \\ Trg Sv. Trojstva 2 \\ HR-31000 Osijek \\ tomislavhrsak@gmail.com
}

\begin{abstract}
Jedno od najznačajnijih nalazišta na jugu Karpatske kotline za kraj kasnoga brončanog i početak starijega željeznog doba predstavlja Batina (Kiskőszeg). Iz Batine je već više od stoljeća poznat niz iznimnih nalaza, danas pohranjenih u nekoliko europskih muzejskih zbirki, za koje se pretpostavlja kako potječu iz uništenih grobnih cjelina, a poslužili su u kronološkom definiranju razvoja daljske grupe. S ciljem određivanja položaja groblja daljske grupe u Batini, proveden je sustavni terenski pregled čiji su rezultati ukazali na mogući položaj groblja na položaju Sredno južno od istovremenoga naselja na Gracu. Potom je uslijedila provedba arheoloških iskopavanja na Srednom u kojima su otkriveni brojni paljevinski grobovi daljske grupe iz kasnoga brončanog i s početka starijega željeznog doba. U grobovima su pronađeni keramički, metalni i stakleni nalazi koji su potvrdili dosadašnje pretpostavke o iznimnoj važnosti Batine kao istaknutoga južnopanonskog centra s kraja 2. i prvih stoljeća 1. tis. pr. Kr. smještenoga na važnoj komunikaciji koja je slijedila tok Dunava.
\end{abstract}

Ključne riječi: starije željezno doba, groblje, Batina, daljska grupa, Karpatska kotlina, keramika, kronologija

Batina (Kisköszeg) is one of the most significant sites in the southern Carpathian Basin from the end of the Late Bronze Age and the beginning of the Early Iron Age. For more than a century, Batina has been the source of many exceptional finds, now stored in the collections of several European museums, which are considered to originate from destroyed funerary complexes and which helped define the chronology of the development of the Dalj Group. A systematic field survey was done to determine the location of the Dalj Group cemetery in Batina. Its results indicated that the cemetery could have been located in Sredno, a site south of the contemporary settlement on Gradac. This was followed by archaeological excavations in Sredno, which revealed many cremation graves of the Dalj Group from the Late Bronze Age and the beginning of the Early Iron Age. The graves contained ceramic, metal and glass finds, confirming the earlier hypotheses about the great significance of Batina as an important southern Pannonian centre from the end of the $2^{\text {nd }}$ millennium BC and the first centuries of the $1^{\text {st }}$ millennium $B C$, which stood on an important communication line along the Danube.

Keywords: Early Iron Age, cemetery, Batina, Dalj Group, Carpathian Basin, ceramic, chronology 


\section{UVOD}

Jedno od najznačajnijih nalazišta s kraja kasnoga brončanog i početka starijega željeznog doba na jugu Karpatske kotline predstavlja Batina (Kiskőszeg) odakle je već više od stoljeća poznat niz iznimnih nalaza koji su danas pohranjeni u nekoliko europskih muzejskih zbirki. Radi se o mnogobrojnim te raznovrsnim metalnim predmetima naoružanja i konjske opreme te predmetima nošnje i nakita za koje se pretpostavlja kako potječu iz uništenih grobnih cjelina. Ipak, u najvećem su broju pronađene karakteristično oblikovane te ukrašene keramičke posude na osnovi koje je groblje pripisano daljskoj grupi (Gallus, Horváth 1939; Kossack 1954; Foltiny 1961; Vinski, Vinski-Gasparini 1962; Nađ, Nađ 1964; Metzner-Nebelsick 1996: 284; 1997: 15; 2002 : $28-32,198,595)$. Raznovrsnost i brojnost prikupljenih nalaza ukazivali su kako je naselje na Gracu u Batini bilo jedan od najistaknutijih centara na jugu Karpatske kotline krajem 2. i u prvim stoljećima 1. tis. pr. Kr. te stjecište različitih mreža kontakata, često sa zabilježenim usporedbama i na udaljenim područjima.'

Batina je smještena na sjeveroistočnome završetku Banskoga brda, na mjestu gdje ono strmo završava na Dunavu. Najstariji tragovi naseljavanja potječu iz mlađega kamenog doba, s kontinuitetom naseljavanja kroz sva razdoblja prapovijesti, o čemu svjedoče rezultati brojnih manjih pokusnih i zaštitnih istraživanja (Bulat 1970a; 1970b; 1977; 1984; Pinterović 1971; Minichreiter 1976; 1987; Bojčić 1977; Šimić 2002) te nalazi prikupljeni u terenskim pregledima (Bulat 1962; 1964; 1974; 1981). Batina se danas, ipak, prepoznaje kao jedno od najistaknutijih nalazišta za razdoblje kraja brončanoga i početak starijega željeznog doba koje je na prostorima Baranje i susjedne jugoistočne Transdanubije, zatim istočne Slavonije i zapadnoga Srijema te jugozapadne Bačke obilježeno razvojem daljske grupe (Childe 1929: 407-409; Vinski-Gasparini 1978; 1983; Tasić 1994: 12), odnosno jugoistočno panonske grupe kulture polja sa žarama i halštatskoga doba (Southeast Pannonian group of the Urnfield and Hallstatt period) (Metzner-Nebelsick 2017a: 350).

S obzirom na rezultate dosadašnjih istraživanja, poznato je kako se na položaju Gradac u Batini nalazilo naselje daljske grupe koje se rasprostiralo na nekoliko uzvišenja koja završavaju strmim lesnim padinama te su još razdijeljena s dubokim prirodnim usjecima (Bulat 1970a: 43; Pinterović 1971: 55-56; Minichreiter 1976: 37-40; Bojčić 1977: 41-43, T. XXIII: 3; XXIV). Naselje je od položaja groblja na Srednom odijeljeno dubokim prirodnim usjekom južno od kojega je zabilježeno i postojanje zemljanih humaka - tumula (Metzner-Nebelsick 1996: 301, sl. 1; 1997a: 15; 2002: 185-187, 198, sl. 85, 87).

S ciljem evidentiranja novih, dosad nepoznatih arheoloških nalazišta kao i radi dokumentiranja onih od prije poznatih na prostoru Baranje, Arheološki muzej u Osijeku, uz sudjelovanje Instituta za arheologiju i Odsjeka za arheologiju HAZU-a, 2008. godine započeo je rad na projektu Arheološka baština Baranje (Bojčić et al. 2009; 2010). ${ }^{2} \mathrm{U}$ jesen iste

1 Ovaj rad financirala je Hrvatska zaklada za znanost projektom (IP-062016-1749): Željeznodobni ženski identiteti na jugu Karpatske kotline (FEMINE).

2 Dosad je terenskim pregledima obuhvaćeno područje od Batine prema Kneževim Vinogradima u kojima su pronađena brojna nalazišta iz svih razdoblja.

\section{INTRODUCTION}

Batina (Kiskőszeg) in Baranya is one of the most important sites from the end of the Late Bronze Age and the beginning of the Early Iron Age in the southern Carpathian Basin. For more than a century, it has been the source of many exceptional finds, which are now stored in the collections of several European museums. They are numerous and diverse metal weaponry items, riding equipment, and items of costume and jewellery, probably originating from destroyed funerary complexes. However, the most numerous finds were the characteristically shaped and decorated ceramic vessels, which were the basis for including the cemetery in the Dalj Group (Gallus, Horváth 1939; Kossack 1954; Foltiny 1961; Vinski, Vinski-Gasparini 1962; Nađ, Nađ 1964; Metzner-Nebelsick 1996: 284; 1997: 15; 2002: 28-32, 198, 595). The great number and diversity of the collected finds indicate that the Gradac settlement in Batina was one of the most important centres in the southern Carpathian Basin at the end of the $2^{\text {nd }}$ millennium and in the first centuries of the $1^{\text {st }}$ millennium BC. It was also a hub for different networks of contacts, often with recorded parallels in remote areas. ${ }^{1}$

Batina lies on the north-east edge of Bansko Brdo, where the hill was cut by the Danube. The oldest traces of settlements start in the Late Stone Age and continue through all the prehistoric ages, as testified by the results of many smaller trial and rescue excavations (Bulat 1970a; 1970b; 1977; 1984; Pinterović 1971; Minichreiter 1976; 1987; Bojčić 1977; Šimić 2002) and the finds collected by field surveys (Bulat 1962; 1964; 1974; 1981). Nowadays, Batina is recognised as one of the most important sites from the period of the end of the Bronze Age and the beginning of the Early Iron Age. This period in the regions of Baranya, the neighbouring south-east Transdanubia, eastern Slavonia, western Syrmia, and south-western Bačka, was marked by the development of the Dalj Group (Childe 1929: 407-409; Vinski-Gasparini 1978; 1983; Tasić 1994: 12) or the Southeast Pannonian group of the Urnfield and Hallstatt period (Metzner-Nebelsick 2017a: 350).

On the basis of the results of past excavations, it is known that the Gradac site in Batina used to be a Dalj Group settlement extending over several prominent elevations ending with steep loess slopes and separated by deep natural ravines (Bulat 1970a: 43; Pinterović 1971: 55-56; Minichreiter 1976: 37-40; Bojčić 1977: 41-43, PI. XXIII: 3; XXIV). The settlement was separated from the Sredno cemetery site by a deep natural ravine, with earth mounds (tumuli) identified south of the ravine (Metzner-Nebelsick 1996: 301, Fig. 1; 1997a: 15; 2002: 185-187, 198, Figs. 85, 87).

In order to record new and previously unknown archaeological sites and to document the known sites in the area of Baranya, the Archaeological Museum in Osijek together with the Institute for Archaeology and the Archaeology Division in the Croatian Academy of Sciences and Arts started the project "The Archaeological Heritage of Baranya" in 2008 (Bojčić et al. 2009; 2010). ${ }^{2}$ A field survey in the autumn

1 This work has been supported in part by the Croatian Science Foundation under the project (IP-06-2016-1749): Iron Age Female Identities in the Southern Carpathian Basin (FEMINE).

2 Field surveys have covered the area from Batina towards Kneževi Vinogradi, where numerous sites from all the periods have been found. 
godine terenskim pregledom obuhvaćen je i širi prostor Batine, odnosno krajnji sjeveroistočni završetak Banskoga brda. Na položaju naselja na Gracu prikupljeni su brojni keramički ulomci koji se mogu datirati u kasno brončano i starije željezno doba, dok su na položaju Sredno pronađeni ulomci keramičkih posuda i spaljenih ljudskih kostiju koji su ukazivali na pretpostavljeni položaj groblja. $\mathrm{Na}$ istome položaju zabilježeno je i postojanje većega broja zemljanih tumula koji slijede jedinu komunikaciju koja je vodila prema naselju, a koji su danas zbog intenzivne poljoprivredne obrade većinom sniženi te su jedva prepoznatljivi u krajoliku (Bojčić et al. 2009). Položaj groblja daljske grupe na Srednom potvrđen je tijekom izgradnje vodovodne mreže 2009. godine kada su pronađena dva paljevinska groba (Dujmić 2011).

Pokusna iskopavanja na položaju Sredno započela su 2010. godine u kojima su, pored rimskih paljevinskih i kosturnih grobova, pronađeni i brojni paljevinski grobovi daljske grupe koji su datirani u kasno brončano i starije željezno doba (Bojčić et al. 2011). Sustavna istraživanja nastavljena su potom u kontinuitetu na različitim položajima na Srednom na kojima su također pronađeni paljevinski grobovi daljske grupe kao i rimski paljevinski te kosturni grobovi (Hršak et al. 2013; 2014; 2015; 2016; 2017). Tako su rezultati dosad provedenih istraživanja potvrdili spoznaje kako je Batina jedno od najistaknutijih arheoloških nalazišta s kraja 2. i početnih stoljeća 1. tis. pr. Kr. na jugu Karpatske kotline.

Rezultati provedenih istraživanja pokazali su kako se groblje daljske grupe rasprostire od južnoga ruba prirodnog usjeka koji je Sredno dijelio od naselja na Gracu. U rijetkim je slučajevima zabilježeno presijecanje grobova, što vjerojatno svjedoči o postojanju vanjskih oznaka grobova. ${ }^{3}$ Svi su grobovi sadržavali spaljene ostatke pokojnika koji su položeni u keramičke posude ili su se nalazili u nekom organskom omotaču (tkanina) te su smješteni na dno groba. Grobne rake najčešće su pravokutnoga ili kvadratnog oblika i zaobljenih uglova te različitih dubina i dimenzija. Kao urne najčešće su se koristili različiti oblici lonaca koji su često bili pokriveni sa zdjelom, no pronađeni su i grobovi u kojima su spaljene kosti položene u zdjelu ili u amforu (Ložnjak Dizdar, Rajić Šikanjić 2016: 113-115, sl. 3). Tijekom istraživanja zabilježeno je i postojanje dvojnih grobova o čemu, osim različitih vrsta nalaza, svjedoči i polaganje spaljenih kostiju u različite keramičke posude. Najbrojnije nalaze u grobovima predstavljaju keramičke posude koje su najvjerojatnije sadržavale popudbinu, što je u nekim grobovima i potvrđeno nalazima životinjskih kostiju u posudama, najčešće u zdjelama. Od keramičkih posuda u najvećem se broju pronalaze različiti oblici lonaca, zdjela i kantharosa, dok su u manjem broju pronađeni vrčevi i šalice, dok se iznimno pojavljuju dvojne posude te stalci. Od metalnih nalaza u grobovima su najčešće pronađeni predmeti nošnje (fibule, igle) i nakita (ukrasi za kosu, narukvice, torkvesi, privjesci) koji najčešće pokazuju tragove spaljivanja s pokojnikom/com na lomači. Metalni predmeti položeni su sa spaljenim ostacima pokojnika u urne, no pronađeni su i u ostacima paljevine s lomače koja se može nalaziti na dnu grobne rake oko urne. Broj

3 Na sjevernome dijelu groblja istražena su i dva tumula u kojima su bili pokopani istaknuti članovi zajednice, o čemu svjedoči postojanje iznimno kompleksne grobne arhitekture te brojni prestižni nalazi koji se mogu datirati u 8. st. pr. Kr. (Hršak et al. 2013; 2015; 2016). of the same year covered the wider area of Batina including the north-east end of Bansko Brdo. Numerous pottery sherds collected on the Gradac settlement site were dated to the Late Bronze Age and the Early Iron Age, while the sherds of ceramic vessels and cremated bones found at the Sredno site indicated the possible position of the cemetery. The same site contains a large number of earth tumuli along the single line of communication towards the settlement, but intense agricultural activity has mostly reduced their height, making them barely noticeable in the landscape (Bojčić et al. 2009). The location of the Dalj Group cemetery at Sredno was confirmed during the construction of the waterworks in 2009, when two cremation graves were found (Dujmić 2011).

Trial excavations at the Sredno site were started in 2010. They found not only Roman cremation and skeleton graves, but also numerous Dalj Group cremation graves dated to the Late Bronze Age and the Early Iron Age (Bojčić et al. 2011). The subsequent continuous and systematic excavations on various locations at Sredno found numerous cremation graves of the Dalj Group and Roman cremation and inhumation graves (Hršak et al. 2013; 2014; 2015; 2016; 2017). The excavation results confirmed that Batina was one of the most important archaeological sites from the end of the $2^{\text {nd }}$ millennium $B C$ and the first centuries of the $1^{\text {st }}$ millennium $B C$ in the southern Carpathian Basin.

The excavation results have shown that the Dalj Group cemetery stretches from the southern edge of the natural ravine separating Sredno from the Gradac settlement. The intercutting of graves was recorded only rarely, which probably means that they were somehow marked on the surface. ${ }^{3}$ All the graves contained the cremated remains of the dead placed in ceramic vessels or in an organic wrapping (textile) and deposed on the bottom of the grave. The grave pits are usually rectangular or square, with rounded corners and different depths and sizes. Urns were most frequently represented by various forms of pots, which were often covered by a bowl, but there were also graves where cremated bones were put in a bowl or amphora (Ložnjak Dizdar, Rajić Šikanjić 2016: 113-115, Fig. 3). The excavations uncovered some double graves, as testified not only by different kinds of finds, but also by the fact that cremated bones were laid in different ceramic vessels. The most numerous finds are ceramic vessels which probably contained food and drink offerings, as confirmed in some graves where animal bones were found in vessels, most frequently bowls. The most numerous ceramic vessels are various forms of pots, bowls and kantharoi. There are fewer jugs and cups, and only exceptionally double vessels and stands. The most frequent metal finds in graves are items of costume (fibulae, pins) and jewellery (hair ornaments, bracelets, torcs, pendants), which often show traces of the cremation with the dead body on the pyre. The metal objects were placed in urns together with the cremated human remains, but they have also been found within the burnt residue from the pyre that sometimes lies around the urn at the bottom of the pit. The

3 Two explored tumuli in the northern part of the cemetery were the graves of prominent members of the community, as testified by the exceptionally complex funerary architecture and numerous prestigious finds that can be dated to the $8^{\text {th }}$ century BC (Hršak et al. 2013; 2015; 2016). 
metalnih predmeta nošnje (fibule) i nakita (ukrasi za kosu, narukvice, torkvesi, privjesci) veći je u grobovima žena u kojima se još nalaze staklene perle, koštani privjesci te keramički pršljeni. Za grobove žena karakteristični su i manji željezni noževi s blago povijenim sječivom i kratkim trnom, kakvi se pojavljuju i u grobovima muškaraca. S druge strane, u grobovima muškaraca, osim predmeta nošnje (igle), još se nalaze predmeti naoružanja i konjske opreme, zatim brusevi te željezne perle.

S obzirom na tipološke karakteristike keramičkih i metalnih nalaza, dosad pronađeni grobovi daljske grupe na Srednom mogu se izdvojiti u dva horizonta pokopavanja stariji koji pripada kraju kasnoga brončanog doba i mlađi - s početka starijega željeznog doba. ${ }^{4}$ Najstariji pronađeni grobovi pripadaju samome početku mlađe faze kulture polja sa žarama (12./11. st. pr. Kr.). ${ }^{5} \mathrm{~S}$ obzirom na oblik amfore koja je poslužila kao urna u grobu 103, grob pripada Ha A2 stupnju, odnosno horizontu groba Dalj - Studenac (Metzner-Nebelsick 2002: 78-79, sl. 18) te pokazuje kako se početak pokopavanja na Srednom može datirati na početak mlađe faze kulture polja sa žarama (Ložnjak Dizdar 2017: 92, sl. 5, 7), odnosno prije izdvojenoga keramičkog horizonta I. Na to ukazuju i neki od ranije poznati nalazi keramičkih posuda iz Batine, također vjerojatno iz uništenih grobova (Metzner-Nebelsick 2002: 83-84, T. 16: 1; 25: 4 itd.). Ipak, u dosad provedenim iskopavanjima na Srednom, grobovi koji bi pripadali keramičkome horizontu I prema podjeli C. Metzner-Nebelsick nisu pronađeni što, prije svega, ovisi o maloj površini dosad provedenih iskopavanja. Potom slijede grobovi koji pripadaju kraju kasnoga brončanog doba, odnosno keramičkome horizontu II. U grobovima ove faze pokopavanja pronađeni su karakteristični daljski vrčevi s okomito kaneliranim trbuhom i ručkom te zdjele zaobljenoga tijela i koso kaneliranoga uvučenog ruba (Metzner-Nebelsick 2002: 169, sl. 73). Mlađoj fazi pokopavanja pripadaju grobovi koji se mogu datirati u početne faze starijega željeznog doba (keramički horizonti IIla-b - IV), s najmlađim dosad pronađenim grobovima iz sredine te druge polovice 7. st. pr. Kr. Za grobove mlađe faze pokopavanja na Srednom karakteristične su veće i ponekad duboko ukopane grobne rake, dok se od keramičkih nalaza u najvećem broju pojavljuju lonci stožastoga vrata ili oni s okomitim kanelurama i rebrima, zatim zdjele zaobljenoga tijela te vodoravno kaneliranoga uvučenog ruba kao i kantharosi ukrašeni metopno organiziranim ornamentima (Metzner-Nebelsick 2002: 169-175, sl. 74-76).

Dosad istraženi grobovi s položaja Sredno imaju dobre usporedbe u od ranije poznatim nalazima daljske grupe iz Batine koji su od iznimne važnosti za prijelaz kasnoga brončanog na starije željezno doba na jugu Karpatske kotline (Vinski, Vinski-Gasparini 1962; Metzner-Nebelsick 2002). Ipak, pronalazak grobova s jasnim kontekstima od izuzetne je važnosti u budućim proučavanjima razdoblja koje je obilježeno s pojavom izrade željeznih predmeta kada dolazi do

\footnotetext{
4 Iz Batine su od ranije poznati i nalazi koji se mogu datirati u stariju fazu kulture polja sa žarama (Metzner-Nebelsick 2002: 81-85, sl. 20; 21: 1-2, 4; T. 40: 1-17; Šimić 2002: 56-59), no bez poznatoga mjesta pronalaska.

5 Zanimljivo, grobovi su zasad pronađeni samo ispod nasipa tumula 1 što ih je i sačuvalo od obrade zemljišta.
}

number of metal items of costume (fibulae) and jewellery (hair ornaments, bracelets, torcs, pendants) is bigger in the graves of women, which also contain glass beads, bone pendants, and ceramic spindle whorls. The graves of women are also characterised by small iron knives with slightly curved blade and short prong, which have also been found in the graves of men. On the other hand, the graves of men contained not only items of costume (pins), but also weaponry and riding equipment, as well as whetstones and iron beads.

Considering the typological characteristics of the ceramic and metal finds, the Dalj Group graves found at Sredno can be divided into two burial horizons: an older one from the end of the Late Bronze Age and a younger one from the beginning of the Early Iron Age. ${ }^{4}$ The oldest graves belong to the very beginning of the younger phase of the Urnfield culture $\left(12^{\text {th }} / 11^{\text {th }}\right.$ century BC). ${ }^{5}$ Considering the shape of the amphora serving as urn in grave 103, the grave belongs to phase $\mathrm{Ha} \mathrm{A} 2$ or to the horizon of grave Dalj - Studenac (Metzner-Nebelsick 2002: 78-79, Fig. 18) and shows that the start of the burials at Sredno can be dated to the beginning of the younger phase of the Urnfield culture (Ložnjak Dizdar 2017: 92, Figs. 5, 7), i.e. before the isolated ceramic horizon I. This is also indicated by some earlier finds of pottery from Batina, which probably also came from destroyed graves (Metzner-Nebelsick 2002: 83-84, PI. 16: 1; 25: 4 etc.). However, the excavations at Sredno have not revealed any graves from ceramic horizon I according to the distribution of $C$. Metzner-Nebelsick, which can mainly be attributed to the fact that the excavations covered a small area. Then there are graves from the end of the Late Bronze Age (ceramic horizon II). The graves from this burial phase contained characteristic Dalj jugs with vertically fluted belly and handle, and bowls with spherical body and obliquely fluted inverted rim (Metzner-Nebelsick 2002: 169, Fig. 73). The graves from the younger burial phase can be dated to the initial phases of the Early Iron Age (ceramic horizons IIla-b - IV), with the youngest graves dating from the middle and the second half of the $7^{\text {th }}$ century BC. The graves from the younger burial phase at Sredno are characterised by large and sometimes deep grave pits; the most numerous pottery finds inside these graves are pots with conical neck or pots with vertical fluting and ribs, bowls with spherical body and horizontally fluted inverted rim, and kantharoi decorated with ornaments organised into metopes (Metzner-Nebelsick 2002: 169-175, Figs. 74-76).

The explored graves from the Sredno site have good parallels in the known Dalj Group finds from Batina, which are exceptionally important for the transition from the Late Bronze Age to the Early Iron Age in the southern Carpathian Basin (Vinski, Vinski-Gasparini 1962; Metzner-Nebelsick 2002). Still, the discovery of graves with clear contexts is very important for future research of the period characterised by

4 Some earlier finds from Batina can also be dated to the older phase of the Urnfield culture (Metzner-Nebelsick 2002: 81-85, Fig. 20; 21: 1-2, 4; P1. 40: 1-17; Šimić 2002: 56-59), but the site of their discovery is unknown.

5 Interestingly, the only graves have been found under the fill of tumulus 1 , which preserved them from agricultural work. 
primjetnih društvenih promjena kao i uspostave novih komunikacijskih mreža.

Neke od grobnih cjelina, koje su pronađene tijekom iskopavanja provedenih 2010. godine, predstavljaju se ovom prilikom. Radi se o tri groba - 36, 37 i 38 - koji su pronađeni u sondi 2 te nisu bili međusobno udaljeni, no zanimljivi su jer prikazuju tri različita vremenska horizonta pokopavanja tijekom starijega željeznoga doba prema kronološkoj klasifikaciji C. Metzner-Nebelsick (2002: 167-177).

Sva tri groba imaju pravokutne grobne rake zaobljenih uglova koje su različitih dimenzija i dubina ukopa (sl. 1-6). U grobovima 36 i 37 spaljeni ostaci pokojnika, zajedno s paljevinom, bili su položeni u keramičke posude u funkciji urne, odnosno u lonce u kojima se, među spaljenim kostima, još nalaze keramički te metalni i stakleni predmeti. U grobu 38 spaljeni ostaci pokojnika nalazili su se, s obzirom na kompaktnost paljevine sa spaljenim kostima, vjerojatno u nekom organskom recipijentu, možda u drvenoj posudi (sl. 6). U grobu 37 u loncu, u kojem nisu bile spaljene kosti, pronađena je šalica, što je zabilježeno i na groblju u Doroslovu (Trajković 2008: 15-16) i Sotinu (Ložnjak Dizdar 2010: 45-58). Do urni su u grobovima 36 i 37 položeni ostaci paljevine, vjerojatno s lomače, u kojima također ima spaljenih kostiju te metalnih i staklenih predmeta (sl. 1-4). Pojedini metalni predmeti pokazuju tragove spaljivanja. Do posuda su pronađene životinjske kosti koje se ponekad nalaze i u zdjelama, kao na primjer u grobu 38 (sl. 5).

\section{GROB 36}

Grob 36 (SJ 142/143), s tamnosmeđom zapunom (10YR 4/4), nalazi se u sondi 2 (sl. 1-2). Pravokutna grobna raka zaobljenih uglova dimenzija je 2,00 x 1,57 m, relativne dubine $0,31 \mathrm{~m}$ te okomitih stijenki. $U$ istočnome dijelu grobne rake nalazi se lonac (PN 286) zaobljenoga tijela i stožastoga vrata, s ljevkasto izvučenim rubom (T. 1: 9). Na prijelazu vrata u rame nalazi se vodoravni žlijeb te nasuprot postavljena bradavičasta izbočenja. U loncu su pronađene spaljene kosti ( $U$ 202) djeteta ${ }^{6}$ te $s$ njima dva keramička pršljena (PN 364-365) (T. 1: 1-2), tamnoplava staklena perla ukrašena s tri motiva oka žute boje (PN 366) (T. 1: 3), brončane vitice (PN 367-368) (T. 1: 4), brončane perle (PN 369) (T. 1:5) te brončane kuglice kao ostaci spaljenih predmeta (PN 370) (T. 1: 6) kojima nije više moguće odrediti izvoran oblik. U zapadnome dijelu groba također su pronađene spaljene kosti odrasle osobe i djeteta (U 151) s paljevinom koje se nalaze na hrpici promjera 0,70 m. Sa pomiješanim spaljenim kostima odrasle osobe i djeteta pronađena je brončana perla (PN 288) (T. 1: 7), dok je pokraj lonca pronađen keramički predmet s četiri zupca (PN 289) (T. 1: 8). U zapuni grobne rake pronađeni su ulomci keramike i životinjske kosti svinje, ovce ili koze, krave te ribe. ${ }^{7}$

6 Analizu antropoloških ostataka iz grobova 36, 37 i 38 provela je dr. sc. Petra Rajić Šikanjić iz Instituta za antropologiju u Zagrebu na čemu joj najsrdačnije zahvaljujemo.

7 Analizu životinjskih kostiju iz grobova 36,37 i 38 proveo je dr. sc. Siniša Radović iz Zavoda za paleontologiju i geologiju kvartara HAZU-a u Zagrebu. the appearance of iron products, significant social changes, and the establishment of new communication networks.

This work presents some of the funerary complexes found during the excavations of 2010 . These three graves - 36, 37, and 38 - were found in Trench 2, not far from one another, but they are interesting because they show three different time horizons of burial during the Early Iron Age according to the chronological classification of $C$. MetznerNebelsick (2002: 167-177).

All three graves have rectangular grave pits with rounded corners and different depths and sizes (Figs. 1-6). In graves 36 and 37, the cremated human remains were placed together with other burnt remains into ceramic vessels serving as urns, i.e. into pots that contained cremated bones mixed with ceramic, metal and glass objects. In grave 38 , the cremated human remains were probably stored in an organic recipient, possibly a wooden vessel, considering the compactness of burnt remains mixed with cremated bones (Fig. 6). A pot without cremated bones in grave 37 contained a cup, which was also recorded at the cemeteries of Doroslovo (Trajković 2008: 15-16) and Sotin (Ložnjak Dizdar 2010: 45-58). The urns in graves 36 and 37 were next to burnt remains, probably from the pyre, which also contained cremated bones and metal and glass objects (Figs. 1-4). Certain metal objects show traces of burning. Vessels stood next to animal bones, which were sometimes placed in bowls, as for example in grave 38 (Fig. 5).

\section{GRAVE 36}

Grave 36 (SU 142/143), with dark brown fill (10YR 4/4), is located in Trench 2 (Figs. 1-2). The rectangular grave pit with rounded edges measures $2.00 \times 1.57 \mathrm{~m}$, with a relative depth of $0.31 \mathrm{~m}$ and vertical sides. In the eastern part of the grave pit there was a pot (SF 286) with spherical body, conical neck, and funnel-shaped everted rim (PI. 1: 9). At the junction of neck and shoulder there is a horizontal groove and opposing protrusions. The pot contained cremated bones (S 202) of a child ${ }^{6}$ together with two ceramic spindle whorls (SF 364-365) (PI. 1: 1-2), a dark blue glass bead decorated with three yellow eye motifs (SF 366) (PI. 1: 3), bronze ringlets (SF 367-368) (PI. 1: 4), bronze beads (SF 369) (PI. 1: $5)$, and bronze spherical knobs as the remains of cremated objects (SF 370) (PI. 1: 6) for which it is impossible to identify the original shape. The western part of the grave also contained the cremated bones of an adult and a child (S 151) with burnt remains on a pile measuring $0.70 \mathrm{~m}$ in diameter. The mixed cremated bones of the adult and the child were together with a bronze bead (SF 288) (PI. 1: 7), while the pot stood next to a ceramic object with four prongs (SF 289) (PI. 1: 8). The fill of the grave pit contained pottery sherds and animal bones of pig, sheep or goat, cow, and fish. ${ }^{\text {? }}$

6 We are grateful to dr. sc. Petra Rajić Šikanjić from the Institute for Anthropological Research in Zagreb for her analysis of the anthropological remains from graves 36,37 , and 38 .

7 The animal bones from graves 36,37 , and 38 were analysed by dr. sc. Siniša Radović from the Institute for Quarternary Paleontology and Geology of HAZU in Zagreb. 


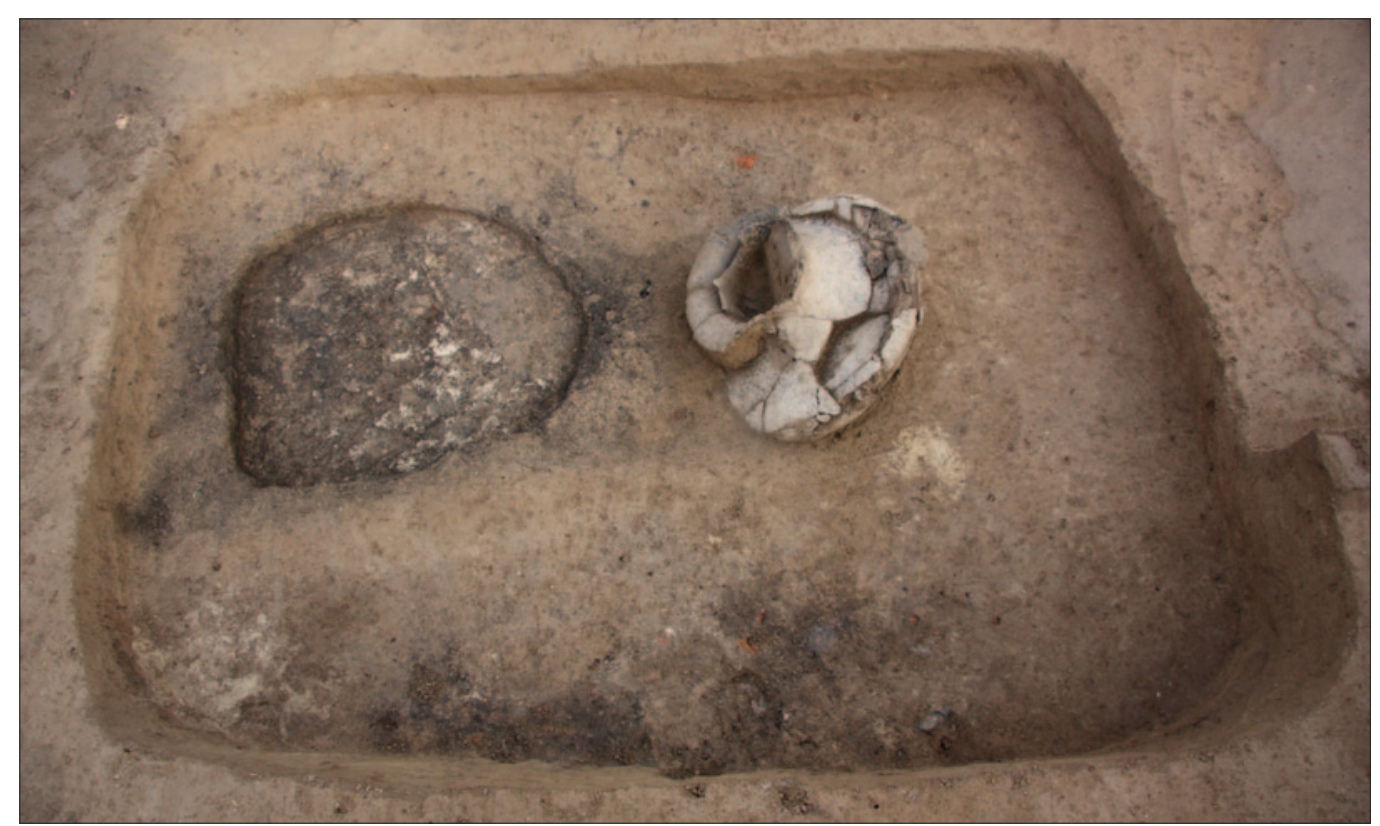

SI. 1 Grob 36 (snimio: V. Mesarić)

Fig. 1 Grave 36 (photo: V. Mesarić)

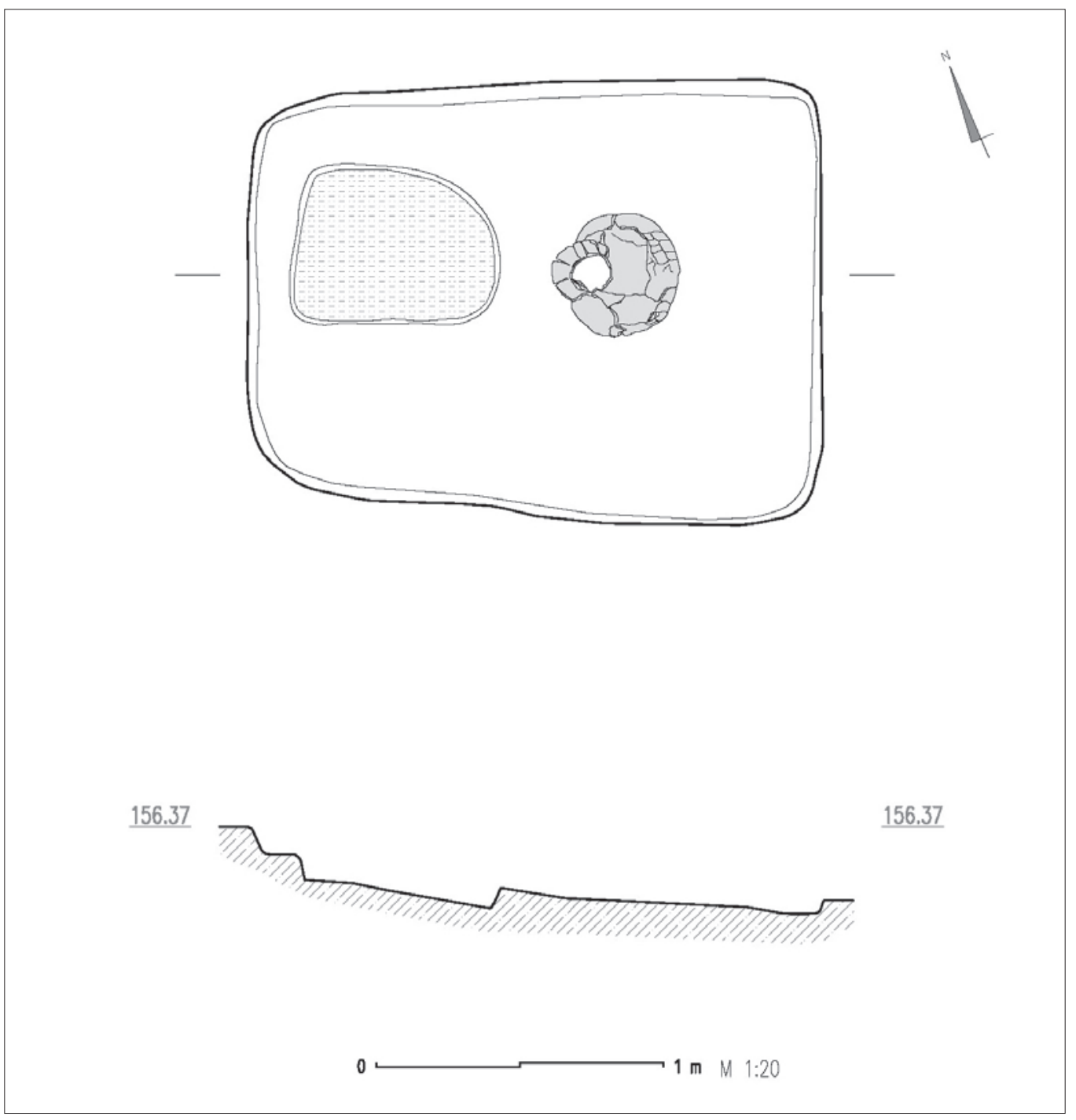

SI. 2 Grob 36 (crtež: D. Radman; priprema: Arheoplan d.o.o.)

Fig. 2 Grave 36 (drawing: D. Radman; preparation: Arheoplan Ltd.) 


\section{Lonac}

Lonac iz groba 36 ima zaobljeno tijelo te stožasti vrat koji prelazi u ljevkasto izvučeni rub. Na prijelazu vrata u rame nalazi se vodoravni žlijeb te nasuprot postavljena bradavičasta izbočenja (T. 1: 9).

Lonci sa stožastim vratom oblik su koji se pojavljuje od keramičkoga horizonta Illa te se, uz određene oblikovne i dekorativne izmjene, nastavljaju sve do horizonta IV. Tako je iz Batine, iz groba s položaja Darašić, poznat nalaz lonca koji ima šire stožasto rame i na njemu četiri bradavičasta izbočenja te ljevkasto izvučeni rub (sl. 7: 1). U grobu je još pronađena zdjela uvučenoga i vodoravno kaneliranoga ruba (sl. 7: 2). Grob je datiran u keramički horizont Illb (Metzner-Nebelsick 2002: 649, T. 47: 3). Najveći je broj usporedbi zabilježen na groblju Dalj - Busija, posebno na položaju vinograda Poštić. Tako iz groba 75/1909 potječe lonac zaobljenoga tijela i stožastoga vrata (Hoffiller 1938: 3, T. 4: 4; Metzner-Nebelsick 2002: T. 81: 5). Oblikom odgovara i lonac iz groba 11/1909 s istoga položaja, no ostali keramički nalazi iz groba ukazuju na stariju fazu pokopavanja, odnosno na keramički horizont II (Hoffiller 1938: 3, T. 5: 2; Metzner-Nebelsick 2002: T. 56: 3). Lonac iz groba 26/1909 također na prijelazu stožastoga vrata u rame ima četiri nasuprot postavljena bradavičasta izbočenja, pri čemu se grob također može pripisati keramičkome horizontu IIla (Hoffiller 1938: 4, T. 7: 6; Metzner-Nebelsick 2002: T. 56: 8). Opisanome obliku pripada i lonac iz groba 63/1909 koji također ima širi stožasti vrat kao i četiri bradavičasta izbočenja na vrhu ramena (Hoffiller 1938: 8, T. 17: 4; Metzner-Nebelsick 2002: 671, T. 81: 2), dok lonac iz groba 98/1909 ima tijelo koje je više bikoničnoga obrisa (Hoffiler 1938: 4, T. 8: 1; Metzner-Nebelsick 2002: T. 82: 2). Navedenoj skupini pripada i lonac sa širim stožastim vratom i četiri bradavičasta izbočenja na vrhu ramena za kojega se kao nalazište navodi Bács - Bodrog (Metzner-Nebelsick 2002: 695, T. 115: 1).

Iz Dalja su poznate još neke grobne cjeline s loncima sa stožastim vratom koje se, prema drugim nalazima, vjerojatno mogu pripisati keramičkome horizontu IIIb (Hoffiller 1938: 3, T. 3: 1; 5: 1, 3; 20: 10; Metzner-Nebelsick 2002: T. 61: 11; 64: 10; 65: 6; 71: 1). Tako iz groba 85/1909 iz vinograda Poštić potječe lonac $s$ naglašenim prijelazom vrata $u$ rame izvedenim u obliku vodoravnoga žlijeba na kojem su, na četiri nasuprot postavljena mjesta, manja bradavičasta izbočenja. Vrat prelazi u jače izvučeni rub. U grobu se još nalaze dva lonca sa stožastim vratom i ramenom ukrašenim sa širokim okomitim kanelurama, zatim stalak i jedna šalica koja izgleda pripada starijim tipološkim oblicima. Lonac sa stožastim vratom iz groba 29/1910 iz vinograda Pavošević ima više bikonično tijelo, a u grobu se još nalaze dva kantharosa i dvije zdjele uvučenoga ruba koji ukazuju na pripadnost keramičkome horizontu IIIb (Hoffiller 1938: 3, T. 5: 1; Metzner-Nebelsick 2002: T. 71: 1). Mlađem obliku lonca sa stožastim vratom pripada i onaj iz groba 3/1909 s položaja vinograda Panišić koji iznad vodoravnoga žljeba ima manja bradavičasta izbočenja te bikonično tijelo (Hoffiller 1938: 3, T. 5: 3; Metzner-Nebelsick 2002: T. 64: 10). Drugi lonac iz spomenutoga groba, koji je upravo karakterističan za horizont IIlb, ima dobru usporedbu u grobu 38. Lonac sa stožastim vratom iz groba 7/1909 također ima bikonični obris tijela

\section{Pot}

The pot from grave 36 has a spherical body and a conical neck merging into a funnel-shaped everted rim. At the junction of neck and shoulder there is a horizontal groove and opposing protrusions (PI. 1: 9).

Pots with conical neck appeared as a shape in ceramic horizon IIla and persisted with certain changes in form and decoration until horizon IV. A grave at the Darašić site in Batina contained a pot with wider conical shoulder that has four protrusions and with funnel-shaped everted rim (Fig. 7: 1). The grave also included a bowl with inverted and horizontally fluted rim (Fig. 7: 2). The grave was dated to ceramic horizon IIlb (Metzner-Nebelsick 2002: 649, PI. 47: 3). The greatest number of parallels was recorded at the Dalj - Busija cemetery, especially at the Poštić vineyard site. For example, grave 75/1909 contained a pot with spherical body and conical neck (Hoffiller 1938: 3, PI. 4: 4; Metzner-Nebelsick 2002: PI. 81: 5). The pot from grave $11 / 1909$ at the same site also has the adequate shape, but other ceramic finds from the grave indicate an older burial phase, i.e. ceramic horizon II (Hoffiller 1938: 3, PI. 5: 2; Metzner-Nebelsick 2002: PI. 56: 3 ). The pot from grave $26 / 1909$ also has four opposing protrusions at the junction of conical neck and shoulder, and that grave can also be associated with ceramic horizon Illa (Hoffiller 1938: 4, PI. 7: 6; Metzner-Nebelsick 2002: PI. 56: 8). Another instance of the described shape is the pot from grave 63/1909, which also has a wide conical neck and four protrusions at the top of the shoulder (Hoffiller 1938: 8, PI. 17: 4; Metzner-Nebelsick 2002: 671, PI. 81: 2), while the pot from grave $98 / 1909$ has a body that is more biconical in shape (Hoffiler 1938: 4, PI. 8: 1; Metzner-Nebelsick 2002: PI. 82: 2). The same group includes the pot with wide conical neck and four protrusions at the top of the shoulder, which was recorded as a find from Bács - Bodrog (Metzner-Nebelsick 2002: 695, PI. 115: 1).

Dalj has other funerary complexes with pots with conical neck. In accordance with other finds, they can probably be associated with ceramic horizon IIIb (Hoffiller 1938: 3, PI. 3: 1; 5: 1, 3; 20: 10; Metzner-Nebelsick 2002: PI. 61: 11; 64: 10; 65: 6; 71: 1). For example, grave 85/1909 from the Poštić vineyard contained a pot with a prominent junction of neck and shoulder shaped as a horizontal groove with small protrusions in four opposite places. The neck merges into the strongly everted rim. The grave included another two pots with conical neck and shoulder decorated with wide vertical fluting, a stand, and a cup that seems to belong to older typological forms. The pot with conical neck from grave $29 / 1910$ from the Pavošević vineyard has a body that is more biconical, and the grave also contained two kantharoi and two bowls with inverted rim, indicating that they belong to ceramic horizon IIlb (Hoffiller 1938: 3, PI. 5: 1; MetznerNebelsick 2002: Pl. 71: 1). The younger form of the pot with conical neck also includes the pot from grave 3/1909 from the Panišić vineyard site, which has small protrusions above the horizontal groove and biconical body (Hoffiller 1938: 3, PI. 5: 3; Metzner-Nebelsick 2002: Pl. 64: 10). The other pot from the same grave, which is characteristic for horizon IIIb, has a good parallel in grave 38. The pot with conical neck from grave 7/1909 also has biconical body shape (Hoffiller 
(Hoffiller 1938: 9, T. 20: 10; Metzner-Nebelsick 2002: T. 65: 6).

Loncu iz groba 36 u Batini oblikom odgovara lonac iz groba 64 u Doroslovu koji je također imao funkciju urne koja je bila poklopljena sa zdjelom uvučenoga i vodoravno kaneliranoga ruba (Trajković 2008: 85, 235/1). U dvojnome grobu 114 također je pronađen lonac sa stožastim vratom u funkciji urne koji na ramenu ima četiri bradavičasta izbočenja (Trajković 2008: 121, 269/1-2). Mlađi oblik iz horizonta Illb predstavljao bi lonac iz groba 27 koji ima tijelo više bikoničnoga obrisa (Trajković 2008: 52, 205/1), kada se može datirati i lonac u funkciji urne iz groba 137 koji na najširem dijelu tijela ima četiri jezičaste drške (Trajković 2008: 149, 298/1). Na isti se način datira i lonac iz groba 9/1963 (sl. 8: 3) koji ima vodoravni žlijeb na prijelazu stožastoga vrata u rame, gdje se nalaze i četiri nasuprot postavljena bradavičasta izbočenja (Trajković 2008: 330, 330/3).

Loncu iz groba 36 oblikom odgovara lonac iz tumula $2 \mathrm{~s}$ Pécs - Jakabhegya koji je datiran u početak starijega željeznog doba, odnosno u prvu polovicu 8. st. pr. Kr. Spomenuti lonac na ramenu ima tri vodoravne kanelure i dvije drške (Metzner-Nebelsick 2002: 78, 101, 704, T. 125B: 10). Sličan lonac, ali $s$ jače naglašenim bradavičastim izbočenjima na ramenu i četiri jezičaste drške na donjem dijelu tijela, pronađen je u Kleinkleinu, položaj Höchschusterwald u tumulu 10 (Dobiat 1980: 66-70, sl. 8: 1; T. 5: 1). Svakako određena oblikovna sličnost postoji i s loncem ukrašenim u Basarabi stilu iz tumula 70 (K) u Frögu koji pripada početku starijega željeznoga doba (Tomedi 2002: 243, T. 41: 1; Metzner-Nebelsick 2002: 102-103, sl. 32: 1). Ovaj tip lonca označen je kao osnovni tip posuda koji se pojavljuje na grobljima u dolini Sulm (Dobiat 1980: 66-73, sl. 10: 1), pri čemu ga je Ch. Pare označio kao prepoznatljiv oblik u zatvorenim cjelinama $\mathrm{Ha}$ C1a stupnja za jugoistočnoalpski prostor (Pare 1999: 348349, sl. 27: 10).

Na osnovi spomenutih usporedbi, kao i ostalih nalaza u grobu, lonac iz groba 36 vjerojatno se može datirati u keramički horizont IIla (Metzner-Nebelsick 1996: 286, sl. 5; 2002: 101-103, 169, sl. 24: 2; 74: 1).

\section{Keramička alatka sa zubcima}

Pored lonca pronađen je keramički predmet tamnosive boje, s okruglim presjekom gornjega dijela i četiri zubca na kraju (T. 1: 8). Gotovo identičan predmet već je poznat iz Batine, vjerojatno s položaja naselja (Metzner-Nebelsick 1997b: 578, sl. 1: 2; 2002: 609, T. 17: 5). Radi se o predmetu koji je zabilježen na nalazištima od srednjega Podunavlja pa sve do srednjega toka Dnjestra te je datiran u 9.-8. st. pr. Kr., a pretpostavlja se kako ima neko simboličko značenje (Metzner-Nebelsick 1997b: 578-579, karta 3; Gogâltan et al. 2015: 104, T. 9). Nalaz u grobu 36 na Srednom pokazuje kako je ovaj keramički oblik vjerojatno povezan sa ženama, sudeći prema položaju nalaza u grobu i prema ostalim prilozima.

\section{Keramički pršljeni}

Čest nalaz u grobovima žena u Batini su keramički pršljeni. Najčešće se nalazi prilog po jednoga pršljena, no ima i grobova u kojima ih je moglo biti i više. Tako su u grobu 36
1938: 9, Pl. 20: 10; Metzner-Nebelsick 2002: Pl. 65: 6).

The pot from grave 36 in Batina has a parallel in the shape of the pot from grave 64 in Doroslovo, which equally served as an urn covered by a bowl with inverted and horizontally fluted rim (Trajković 2008: 85, 235/1). Double grave 114 also contained a pot with conical neck serving as urn, with four protrusions on the shoulder (Trajković 2008: 121, 269/1-2). A younger shape from horizon IIIb is represented by the pot from grave 27 , which has a body with a more biconical shape (Trajković 2008: 52, 205/1), and the same dating can be used for the pot serving as urn from grave 137, which has four tanged handles on the widest part of the body (Trajković 2008: 149, 298/1). The same dating applies to the pot from grave 9/1963 (Fig. 8: 3), which has a horizontal groove at the junction of conical neck and shoulder, where there are four opposing protrusions (Trajković 2008: 330, 330/3).

The pot from grave 36 has a parallel in the shape of the pot from tumulus 2 at Pécs - Jakabhegy, dated to the beginning of the Early Iron Age, i.e. to the first half of the $8^{\text {th }}$ century BC. The shoulder of this pot has three horizontal flutes and two handles (Metzner-Nebelsick 2002: 78, 101, 704, PI. 125B: 10). A similar pot, but with more prominent protrusions on the shoulder and four tanged handles on the lower body, has been found in Kleinklein, in tumulus 10 of the Höchschusterwald site (Dobiat 1980: 66-70, Fig. 8: 1; PI. 5: 1). Moreover, there is definitely a certain formal similarity with the Basarabi-style decorated pot from tumulus 70 (K) in Frög, which belongs to the beginning of the Early Iron Age (Tomedi 2002: 243, Pl. 41: 1; Metzner-Nebelsick 2002: 102-103, Fig. 32: 1). This type of pot has been described as the basic type of vessels appearing at the cemeteries of the Sulm valley (Dobiat 1980: 66-73, Fig. 10: 1), and Ch. Pare described it as the recognisable form in the closed complexes of phase $\mathrm{Ha} \mathrm{C1a}$ for the south-eastern Alpine area (Pare 1999: 348-349, Fig. 27: 10).

On the basis of these comparisons, as well as other finds in the grave, the pot from grave 36 can probably be dated to ceramic horizon Illa (Metzner-Nebelsick 1996: 286, Fig. 5; 2002: 101-103, 169, Fig. 24: 2; 74: 1).

\section{Ceramic tool with prongs}

The pot stood next to a dark grey ceramic object of circular cross-section of the upper body and four prongs at the end (PI. 1: 8). An almost identical object was found earlier in Batina, probably at the settlement site (Metzner-Nebelsick 1997b: 578, Fig. 1: 2; 2002: 609, PI. 17: 5). This object has been recorded at sites from the middle Danube to the middle Dniester and dated to the $9^{\text {th }}-8^{\text {th }}$ century $B C$, with the assumption that it had a symbolic meaning (Metzner-Nebelsick 1997b: 578-579, Map 3; Gogâltan et al. 2015: 104, PI. 9). The find from grave 36 at Sredno shows that this ceramic form was probably associated with women, considering its position in the grave and in relation to other grave goods.

\section{Ceramic spindle whorls}

Ceramic spindle whorls have been frequently found in the graves of women in Batina. Most often, the finds consisted of a single spindle whorl, but there are graves which 
pronađena dva pršljena - jedan bikoničnoga oblika i smeđe boje te uglačane površine (T. 1: 1), dok je drugi diskoidnoga oblika, također je smeđe boje te grube izrade (T. 1: 2). Zasad se izdvaja nalaz groba 105 u kojem je u urni pronađeno čak 20 bikoničnih pršljena (Hršak et al. 2017: 41-42, sl. 2-3).

Usporedbe za bikonični pršljen iz groba 36 također su poznate iz same Batine (Metzner-Nebelsick 2002: 599, T. 5: 11), zatim iz Dalja (Metzner-Nebelsick 2002: 667, T. 65: 5) te Erduta (Metzner-Nebelsick 2002: 687, T. 106: 7). Iz Batine su poznati i nalazi pršljena diskoidnoga oblika (Metzner-Nebelsick 2002: 599, 609, T. 5: 24; 17: 18).

Na groblju u Doroslovu u grobovima se također najčešće nalazi prilog po jednoga ili dva pršljena, pri čemu su oni bikoničnoga oblika najbrojniji (Vasić 2008: 342). Dakle, radi se o karakterističnome rodnom predmetu koji se pojavljuje samo u grobovima žena tijekom svih faza pokopavanja na grobljima daljske grupe, pa tako i u Batini. Pršljeni su česti u grobovima istočnoga halštatskog kruga (Grömer 2016: 83-84, sl. 39). Ipak, ne može se isključiti kako pokojnice u čijim su grobovima pronađeni pršljeni nisu poznavale i druge vještine u procesu izrade tkanina, sudeći prema drugim nalazima vezanim uz umijeće tkanja i šivanja tkanina kao npr. u grobu A014 iz Statzendorfa gdje je pronađena i kutijica s priborom za šivanje (Grömer 2016: 276-277, sl. 149). Česti nalazi pršljena u grobovima svjedoče kako su vjerojatno mnoge pripadnice zajednice prele te kako je ta svakodnevna aktivnost bila važna u ekonomiji zajednice.

\section{Brončane vitice}

U urni su, sa spaljenim kostima i perlama, pronađene brončane vitice prebačenih krajeva i okrugloga presjeka (T. 1: 4 ). Najveći broj vitica pokazuju tragove spaljivanja te je dijelom izgubio prvotni oblik, no ipak se može zaključiti kako se radi o ostacima vitica. Isto tako, prikupljeni su i sitni ulomci brončanih predmeta koji su u potpunosti izgubili svoj osnovni oblik (T. 1: 6).

Brončane vitice $u$ većem su broju od ranije poznate iz Batine (Metzner-Nebelsick 2002: 602, T. 8: 29-34; 607, T. 14: 12-13; T. 15: 4; 610, T. 18: 23-24; 612, T. 20: 2; 642, T. 39 : 7-10) te su predstavljale karakterističan ukras za kosu žena (Metzner-Nebelsick 2002: 433-434). Isto tako, poznate su i s groblja u Dalju (Metzner-Nebelsick 2002: 670, T. 74: 1-3, 7; 676, T. 98: 33-38). Na groblju u Doroslovu brončane vitice također su pronađene u ženskim grobovima te se pojavljuju u različitom broju, od jedne do više njih u bogatije opremljenim grobovima. Često su spaljene, slično grobu 36 iz Batine, a zabilježene su u grobovima koji se, na osnovi ostalih priloga, datiraju u starije željezno doba (Vasić 2008: 342-343). ${ }^{8}$ Vitice su vjerojatno bile nošene upletene

8 U grobu 6 jedna (Trajković 2008: 30, 183/11); u grobu 16 jedna (Trajković 2008: 41, 194/9); u grobu 21 jedna (Trajković 2008: 48, 200/10); u grobu 30 tri vitice (Trajković 2008: 55-56, 210/13-15); u grobu 32 više njih spojenih (Trajković 2008: 58, 211/12); u grobu 33 dvije, od kojih jedna ima ukrašene krajeve (Trajković 2008: 60, 213/17-18); u grobu 42 četiri vitice i jedna spaljena (Trajković 2008: 65, 218/10-13, 15); u grobu 46 dvije oštećene spaljivanjem (Trajković 2008: 70, 222/7-8); u grobu 50 četiri spaljene vitice (Trajković 2008: 73, 226/11-14); velik broj vitica u dvojnome grobu 51 (Trajković 2008: 75-76, 228/8-21); u grobu 52 dvije (Trajković 2008: 77, 229/8-9); u bogatome grobu 58 više vitica (Trajković 2008: 81, 232/8-10, 233/12, 15); u grobu 70 spaljena vitica (Trajković 2008: 90, 239/5); u bogatome grobu 90 brojne spiralne vitice koje pokazuju tragove spaljivanja (Trajković 2008: 250/14, 16-18, 23-24); u grobu 92 tri (Trajković 2008: 105-106, 253/13-15); u grobu 110 ulomci spaljenih could have contained several. For example, grave 36 contained two spindle whorls - a biconical one that is polished and brown (PI. 1: 1) and a discoid one that is rough and also brown (PI. 1: 2). The find that stands out for now is the one from grave 105, which contained an urn with as many as 20 biconical spindle whorls (Hršak et al. 2017: 41-42, Figs. 2-3).

Moreover, the biconical spindle whorl from grave 36 has known parallels in Batina (Metzner-Nebelsick 2002: 599, PI. 5: 11), Dalj (Metzner-Nebelsick 2002: 667, Pl. 65: 5), and Erdut (Metzner-Nebelsick 2002: 687, Pl. 106: 7). Also, discoid spindle whorls have been found in Batina (Metzner-Nebelsick 2002: 599, 609, PI. 5: 24; 17: 18).

The graves at the Doroslovo cemetery most often also contained one or two spindle whorls as grave goods, with biconical spindle whorls being most numerous (Vasić 2008: 342). Therefore, it was a characteristic gender object appearing only in graves of women during all the burial phases at the Dalj group cemeteries including Batina. Spindle whorls are frequent in the graves of the eastern Hallstatt sphere (Grömer 2016: 83-84, Fig. 39). However, it should not be ruled out that the dead women whose graves contained spindle whorls knew other textile-making skills, judging by other finds related to the textile weaving and sewing skill, such as grave A014 in Statzendorf, which contained a small box with a sewing kit (Grömer 2016: 276-277, Fig. 149). The frequent finds of spindle whorls in graves testify that many community members probably spun and that it was an important everyday activity in the economy of the community.

\section{Bronze ringlets}

Aside from cremated bones and beads, the urn contained bronze ringlets with folded terminals and circular cross-section (PI. 1: 4). Most ringlets show traces of burning and have partly lost their original shape; nevertheless, it can be concluded that these are the remains of ringlets. Also, there are tiny fragments of bronze objects that have completely lost their original shape (PI. 1:6).

Large numbers of bronze ringlets are already known from Batina (Metzner-Nebelsick 2002: 602, PI. 8: 29-34; 607, PI. 14: 12-13; PI. 15: 4; 610, PI. 18: 23-24; 612, PI. 20: 2; 642, PI. 39: 7-10), where they were a characteristic decoration for women's hair (Metzner-Nebelsick 2002: 433-434). They are also known from the Dalj cemetery (Metzner-Nebelsick 2002: 670, PI. 74: 1-3, 7; 676, PI. 98: 33-38). The bronze ringlets from the Doroslovo cemetery were also found in women's graves, appearing in different numbers, from a single ringlet to several in richly decorated graves. They are often burned similarly to grave 36 from Batina and found in graves that have been dated to the Early Iron Age on the basis of other finds (Vasić 2008: 342-343). ${ }^{8}$ The ringlets were

8 One ringlet in grave 6 (Trajković 2008: 30, 183/11); one in grave 16 (Trajković 2008: 41, 194/9); one in grave 21 (Trajković 2008: 48, 200/10); three in grave 30 (Trajković 2008: 55-56, 210/13-15); several linked ringlets in grave 32 (Trajković 2008: 58, 211/12); two in grave 33, one of them with decorated terminals (Trajković 2008: 60, 213/17-18); four ringlets and a burnt one in grave 42 (Trajković 2008: 65, 218/10-13, 15); two ringlets damaged by burning in grave 46 (Trajković 2008: 70, 222/7-8); four burnt ringlets in grave 50 (Trajković 2008: 73, 226/11-14); a large number of ringlets in double grave 51 (Trajković 2008: 75-76, 228/8-21); two in 
na kosu. Vitice za kosu čest su nalaz u grobovima mlađe faze kasnoga brončanog doba i tijekom starijega željeznog doba (Vasić 1996: 16-17, sl. 1). Ovakav tip brončanoga ukrasa za kosu, načinjen od deblje brončane žice, karakterističan je nalaz u grobovima u Batini, Dalju, Sotinu i Doroslovu te se ovaj tip može označiti kao lokalni tip ukrasa za kosu u južnome dijelu srednjega Podunavlja (Ložnjak Dizdar, Rajić Šikanjić 2016: 119, sl. 6: 4).

\section{Brončane perle}

U urni su, sa spaljenim ostacima pokojnice, pronađene 43 brončane perle (T. 1: 5), dok je jedna (T. 1: 7) pronađena u paljevini koja predstavlja ostatke s lomače s većinom kostiju odrasle osobe, a nalazila se pokraj urne.

Iz Batine su od ranije poznate brončane perle istoga oblika (Metzner-Nebelsick 2002: 458, 603, T. 9: 1), kao i iz Dalja (Metzner-Nebelsick 2002: 676, T. 98: 32) te Sotina grob 56. Na groblju u Doroslovu perle su također zabilježene u grobovima koji su najčešće datirani u starije željezno doba. ${ }^{9}$ Isto tako, u tumulu 224 s groblja Sopron - Várhegy pronađena je jedna brončana perla, pri čemu se tumul datira u ranu fazu starijega željeznog doba (Patek 1982b: 173; 1983: 145, sl. 20: 2). Ovakve perle pojavljuju se na području Češke i Donje Austrije. Velik broj perli pronađen je u groblju Maiersch u Donjoj Austriji, datiranom od 8. do 6. st. pr. Kr. (Berg 1962: 13, T. 4: 6; 9: 14; 10:3-4; 23:4, 8). Zanimljivo je kako su u kosturnome grobu 31 u Maierschu slične perle nađene kod ramena te kod lijeve i desne ruke (Berg 1962: 22, T. 9: 14; 10:3-4), dok se u kosturnim grobovima $26,72,88$ preko stotinu takvih perli nalazilo na upletenome pojasu (Berg 1962: 19, 31, 34, T. 5: 2; 21: 1; 27: 1). Primjeri kosturnih grobova iz Maierscha pokazuju kako su ovakve perle mogle imati više dekorativnih namjena, no točni konteksti gdje su se nalazile na nošnji pokojnica spaljivanjem tijela zauvijek su izgubljeni.

\section{Staklena perla s očima}

U urni je pronađena i tamnoplava staklena perla koja je ukrašena s tri motiva oka žute boje (T. 1: 3) koje se, inače, smatraju karakterističnim oblikom za starije željezno doba (Kunter 1995: 123-130). Pokojnica je staklenu perlu mogla nositi na istoj ogrlici s brojnim brončanim perlama.

Od ranije iz Batine potječu ovalne purpurne perle koje su ukrašene s tri žuta motiva oka (Metzner-Nebelsick 2002: 458, 602, T. 8: 15-16), dok je iz Dalja poznata tamnoplava perla također ukrašena s tri žuta motiva oka (Metzner-Ne-

vitica (Trajković 2008: 117, 265/9-10); u grobu 115 jedna (Trajković 2008: 123, 271/8); u grobu 123 više vitica (Trajković 2008: 130, 278/8-12); u grobu 128 tri (Trajković 2008: 137, 286/16-18); u grobu 139 dvije (Trajković 2008: 154-155, 303/7-8); u bogatome grobu 141 veći broj vitica (Trajković 2008: 158-159, 307/17-21, 308/22-25, 27); u grobu 144 više vitica od kojih je dio spaljen (Trajković 2008: 161-162, 310/5-6, 11-13); u grobu 149 dvije (Trajković 2008: 169, 318/8-9); u grobu 151 više vitica (Trajković 2008: 171-172, 320/8-9, 13-15, 321/17).

9 U grobu 52 pronađene su dvije brončane perle okrugloga presjeka (Trajković 2008: 77, 229/10-11); u grobu 84 bilo je više brončanih perli, pri čemu grob pripada starijoj fazi pokopavanja iz mlađe faze kulture polja sa žarama (Trajković 2008: 98, 246/5-6); u bogato opremljenome grobu 90, s bimetalnom višeglavom iglom, pronađene su dvije spaljene perle (Trajković 2008: 103, 250/15); u grobu 128 pronađena je brončana perla od trakastoga lima s krajevima koji se preklapaju promjera $0,7 \mathrm{~cm}$ (Trajković 2008: 137, 286/15). probably entwined in hair. Hair ringlets are a frequent find in the graves of the younger phase of the Late Bronze Age and in the Early Iron Age (Vasić 1996: 16-17, Fig. 1). This type of bronze hair decoration, made of thick bronze wire, is a characteristic find in the graves of Batina, Dalj, Sotin, and Doroslovo, and it can be described as the local type of hair decoration in the southern part of the middle Danube (Ložnjak Dizdar, Rajić Šikanjić 2016: 119, Fig. 6: 4).

\section{Bronze beads}

Aside from the cremated remains of a woman, the urn contained 43 bronze beads (PI. 1: 5), while one (PI. 1: 7) was found in the burnt remains next to the urn, which were the rests of the pyre with most bones belonging to an adult.

There were earlier finds of bronze beads with the same shape in Batina (Metzner-Nebelsick 2002: 458, 603, PI. 9: 1), Dalj (Metzner-Nebelsick 2002: 676, PI. 98: 32), and Sotin (grave 56). Beads were also found at the Doroslovo cemetery, in graves which were most often dated to the Early Iron Age. ${ }^{9}$ Moreover, a bronze bead was found at the Sopron Várhegy cemetery, in tumulus 224, which was dated to the early phase of the Early Iron Age (Patek 1982b: 173; 1983: 145, Fig. 20: 2). Such beads have been found in the Czech Republic and Lower Austria. A large number of beads were found at the Maiersch cemetery in Lower Austria, dated to the period from the $8^{\text {th }}$ to $6^{\text {th }}$ century BC (Berg 1962: 13, PI. $4: 6 ; 9: 14 ; 10: 3-4 ; 23: 4,8)$. Interestingly, inhumation grave 31 in Maiersch contained similar beads next to the shoulder and the left and right arm (Berg 1962: 22, PI. 9: 14; 10: $3-4$ ), while skeleton graves $26,72,88$ contained more than a hundred such beads on a woven belt (Berg 1962: 19, 31, 34, PI. 5: 2; 21: 1; 27: 1). The examples of inhumation graves from Maiersch show that such beads could have had several decorative purposes, but the exact contexts of their positions on the dead women's clothes were lost forever when the bodies were cremated.

\section{Glass bead with eyes}

The urn also included a dark blue glass bead decorated with three motifs of a yellow eye (PI. 1: 3) which are generally considered to be a characteristic form of the Early Iron Age (Kunter 1995: 123-130). The woman could have carried

grave 52 (Trajković 2008: 77, 229/8-9); several ringlets in rich grave 58 (Trajković 2008: 81, 232/8-10, 233/12, 15); a burnt ringlet in grave 70 (Trajković 2008: 90, 239/5); numerous spiral ringlets with traces of burning in rich grave 90 (Trajković 2008: 250/14, 16-18, 23-24); three in grave 92 (Trajković 2008: 105-106, 253/13-15); fragments of burnt ringlets in grave 110 (Trajković 2008: 117, 265/9-10); one in grave 115 (Trajković 2008: 123, 271/8); several ringlets in grave 123 (Trajković 2008: 130, 278/8-12); three in grave 128 (Trajković 2008: 137, 286/16-18); two in grave 139 (Trajković 2008: 154-155, 303/7-8); several ringlets in rich grave 141 (Trajković 2008: 158-159, 307/17-21, 308/22-25, 27); several ringlets in grave 144, some of them burnt (Trajković 2008: 161-162, 310/5-6, 11-13); two in grave 149 (Trajković 2008: 169, 318/8-9); several ringlets in grave 151 (Trajković 2008: 171-172, 320/8-9, 13-15, 321/17).

9 Grave 52 contained two bronze beads of circular cross-section (Trajković 2008: 77, 229/10-11); several bronze beads were found in grave 84, which belongs to the older burial phase from the younger phase of the Urnfield culture (Trajković 2008: 98, 246/5-6); richly furnished grave 90, with a bimetal multi-headed pin, contained two burnt beads (Trajković 2008: 103, 250/15); grave 128 included a bronze bead of strap tin with overlapping terminals measuring $0.7 \mathrm{~cm}$ in diameter (Trajković 2008: 137, 286/15). 
belsick 2002: 676, T. 98: 30). U tumulu 24 na groblju Pécs Jakabhegy pronađene su dvije perle, jedna plava i druga tamnoplava sa žutim motivima oka. U grobu su još pronađene i zlatne perle (Patek 1982b: 164, 174).

Opisane se perle u najvećem broju pojavljuju u ženskim grobovima pod tumulima na groblju Sopron - Várhely (Burgstall). U tumulu 224, datiranom u fazu III s dvopetljastom lučnom fibulom s ukrašenim lukom i nožicom, odnosno s početka starijega željeznog doba, pronađen je velik broj keramičkih posuda (38) kao i dva pršljena. Pronađeno je i 25 tamnoplavih perli s tri žuta motiva oka te 6 plavih perli, pri čemu je dio perli bio spaljen s pokojnicom (Patek 1982a: 13, 37, Tab. 1; 1982b: 172-173, T. I; 1983: 145, 169-170, sl. 14; 20: 6). U tumulu 177 pronađeno je čak 38 perli te 885 malih, od kojih je dio također spaljen. U grobu je još pronađeno 7 pršljena te 16 keramičkih posuda (Patek 1982b: 168172, T. II). Perle ovoga oblika i ukrasa još su poznate $s$ istoga nalazišta, no iz nepoznatoga konteksta (Patek 1982b: 161, T. V: 4; 1983: 169). U tumulu 27, s harfastom fibulom i torkvesom, pronađeno je 12 perli s motivom oka te velik broj keramičkih posuda, među njima i ona s prizorima tkanja (Eibner-Persy 1980: 51, 134, T. 15: 6; Patek 1982b: 173, T. VII: 6). U tumulu 148, s torkvesom, pronađeno je 14 perli s motivom oka od kojih neke imaju i točku u sredini, kao i drugi oblici perli. Radi se o pokopu mlađe ženske osobe (Eibner-Persy 1980: 51, 184-185, T. 76: 1-2; Patek 1982b: 173, T. VIII: 1-2) koji je datiran u rani Ha C (Teržan 1990: 179-180). U tumulu 59 pronađeni su različiti oblici perli, među njima i one sa žutim motivom oka i točkom u sredini (Eibner-Persy 1980: 51, 164, T. 59: 1; Patek 1982b: 173, T. IX: 1), dok su u tumulu 139, u keramičkoj posudi, pronađene spaljene perle različitih oblika među kojima ima i onih s motivom oka i točkom u sredini (Eibner-Persy 1980: 51, 181, T. 72: 2; Patek 1982b: 173, T. IX: 9).

U tumulu $V$ na groblju Fischau am Steinfeld pronađeno je pet deformiranih perli u paljevini, no ima i onih koje nisu spaljene, i to 13 plavih perli s tri dvostruka žuta motiva oka. U grobu su pronađeni polumjesečasta fibula i brončani torkves s čvorovima te urna koja je na ramenu ukrašena $s$ motivom ptice kao i noga zdjele te zdjela na nozi koje su ukrašene s prikazima konja (Szombathy 1924: 177-178, T. VII: 787-788). Polumjesečasta fibula datira tumul u rani $\mathrm{Ha}$ C (Teržan 1990: 179-180). Još su u tumulu XII, u paljevini s lomače, pronađene deformirane perle, no bilo je i onih cjelovito sačuvanih (Szombathy 1924: 191, T. XIV: 922). U grobu 1 na groblju Masser - Kreuzbauer u Štajerskoj pronađene su dvije tamnoplave perle s tri motiva oka sastavljena od dvije kružnice, dok je jedna perla ukrašena s dvije kružnice. Grob je datiran u Ha C1a (Bernhard, Weihs 2003: 79, 84-85, T. 4: 10-11; 51-52). Iz Kleinkleina, iz tumula 33 skupine Ofenmacherwald, potječe osam tamnoplavih perli s tri žuta motiva oka, a pronađene su u grobu s čvorastom fibulom (Dobiat 1980: T. 17: 4).

Usporedbe su pokazale kako se na groblju Sopron Várhely, pa i Fischau am Steinfeld, u grobovima pojavljuje daleko veći broj staklenih perli ukrašenih s motivima oka, čak i različitih tipova, što je prepoznatljiva razlika u odnosu na grob 36 iz Batine te tumule iz Pécs - Jakabhegya gdje su zabilježeni tek pojedinačni nalazi perli. Za perle iz So- the glass bead on the same necklace with numerous bronze beads.

Earlier finds from Batina include oval purple beads decorated with three motifs of a yellow eye (Metzner-Nebelsick 2002: 458, 602, PI. 8: 15-16); a dark blue bead from Dalj is also decorated with three yellow eye motifs (Metzner-Nebelsick 2002: 676, PI. 98: 30). Tumulus 24 at the Pécs - Jakabhegy cemetery contained two beads - one blue and one dark blue with yellow eye motifs. The grave also contained gold beads (Patek 1982b: 164, 174).

The described beads appear in the greatest number in women's graves under the tumuli at the Sopron - Várhely cemetery (Burgstall). Tumulus 224, dated to phase III because of a two-loop bow fibula with a decorated bow and foot, i.e. dating from the beginning of the Early Iron Age, contained a large number of ceramic vessels (38) and two spindle whorls. There were also 25 dark blue beads with three yellow eye motifs and 6 blue beads, some of them burned together with the body (Patek 1982a: 13, 37, Tab. 1; 1982b: 172-173, PI. I; 1983: 145, 169-170, Fig. 14; 20: 6). Tumulus 177 contained as many as 38 beads and 885 small ones, some of them also burned. The grave also included 7 spindle whorls and 16 ceramic vessels (Patek 1982b: 168-172, PI. II). Other beads with such shapes and decorations have been found at the same site, but their context is unknown (Patek 1982b: 161, PI. V: 4; 1983: 169). Tumulus 27, with a harp fibula and a torc, contained 12 beads with the eye motif and a large number of ceramic vessels, including one with images of weaving (Eibner-Persy 1980: 51, 134, PI. 15: 6; Patek 1982b: 173, PI. VII: 6). Tumulus 148, which had a torc, included 14 beads with the eye motif, some of them with a dot in the centre, as well as other forms of beads. It was the burial of a young woman (Eibner-Persy 1980: 51, 184-185, PI. 76: 1-2; Patek 1982b: 173, PI. VIII: 1-2), dated to early Ha C (Teržan 1990: 179-180). Tumulus 59 contained various forms of beads, including those with a yellow eye motif and a dot in the centre (Eibner-Persy 1980: 51, 164, PI. 59: 1; Patek 1982b: 173, PI. IX: 1), while tumulus 139 contained a ceramic vessel with burnt beads of various sizes, including those with the eye motif and a dot in the centre (Eibner-Persy 1980: 51, 181, PI. 72: 2; Patek 1982b: 173, PI. IX: 9).

Tumulus $\mathrm{V}$ at the Fischau am Steinfeld cemetery included five deformed beads in the burnt remains, but there were also those that were not burned: 13 blue beads with three double yellow eye motifs. The grave contained a crescent fibula, a bronze torc with loops, an urn decorated with a bird motif on the shoulder, and a bowl foot and a footed bowl decorated with images of horses (Szombathy 1924: 177-178, PI. VII: 787-788). The crescent fibula dates the tumulus to early Ha C (Teržan 1990: 179-180). The burnt remains of the pyre in tumulus XII contained deformed pearls, but others were preserved whole (Szombathy 1924: 191, PI. XIV: 922). Grave 1 at the Masser - Kreuzbauer cemetery in Styria included two dark blue beads with three eye motifs made of two circles, while one bead was decorated with two circles. The grave was dated to $\mathrm{Ha} \mathrm{Cla} \mathrm{(Bernhard,} \mathrm{Weihs}$ 2003: 79, 84-85, PI. 4: 10-11; 51-52). Tumulus 33 of the Ofenmacherwald group in Kleinklein contained eight dark blue beads with three yellow eye motifs, which were found in a 
prona pretpostavlja se kako se radi o importu pristiglom trgovinom (Patek 1982b: 161), pri čemu se primjećuje kako in nema na nekim istovremenim grobljima u zapadnoj Mađarskoj, odnosno najbrojnije su na nalazištima oko Soprona (Patek 1982b: 162-166, 173, 175). Najčešće su one male jednobojne te one plave sa žutim motivima oka koje se smatraju za najčešće oblike na prostoru istočne halštatske kulture (Patek 1982b: 174).

Grob 36 može se prema tipu lonca koji se pojavljuje od jugoistočnoalpskoga prostora (Frög, Klein Klein) do srednjega Podunavlja te staklenoj perli datirati u Illa horizont prema C. Metzner-Nebelsick (2002: 169-172, sl. 74: 1), odnosno u Ha Cla fazu prema Ch. Pareu (1999: 347, sl. 27: 10; Tab. 4).

\section{GROB 37}

Grob 37 (SJ 144/145), s tamnosmeđom zapunom (10YR 4/6), nalazi se u sondi 2 (sl. 3-4). Pravokutna grobna raka zaobljenih uglova dimenzija je 1,41 x 0,95 m, relativne dubine $0,36 \mathrm{~m}$ te okomitih stijenki. $\mathrm{U}$ sjeverozapadnome dijelu grobne rake nalazi se veliki lonac (PN 292) (T. 2: 3) sa spaljenim kostima starije odrasle osobe (U 157; U 200). Lonac ima bikonično tijelo i odmah ispod prijelaza ramena u donji dio, na četiri nausprot postavljena mjesta, jezičaste drške. Rame lonca prelazi u kratki ljevkasti vrat te se na prijelazu nalazi vodoravna plastična traka $s$ otiscima prsta. Do lonca se $u$ sjeveroistočnom uglu groba nalazi sloj paljevine sa spaljenim ljudskim kostima (U 154) na čijem se južnome rubu nalaze brončani profilirani završetak višeglave igle (PN 293) (T. 2: 1) te staklena perla (PN 371) (T. 2: 2). Uz istočni rub groba položene su životinjske kosti - ostaci lopatica dvije krave (U 155) (sl. 4). U jugozapadnome dijelu groba nalazi se kantharos (PN 290) (T. 3: 2) bikoničnoga tijela i stožastoga ramena koji je ukrašen s vodoravnim nizom kružnih udubljenja ispod kojih se nalazi metopno organizirani ukras sastavljen od po četiri kružna udubljenja koja se izmjenjuju sa snopom sastavljenim od okomito postavljenih kanelura. Ručke su blago zadebljane uz rubove te prelaze preko ruba posude. Istočno od kantharosa je lonac (PN 291) bikoničnoga tijela i kratkoga cilindričnog vrata (T. 3: 3a-b). Na prijelazu vrata u rame nalazi se vodoravna plastična traka ispod koje se, na tri mjesta na ramenu lonca, nalazi plastični ukras u obliku okomite trake koja se dijeli i završava sa svake strane u jednome spiralnom zavoju. Okomiti dio trake i dio spirala, nakon račvanja, ukrašen je još s kosim urezima. U loncu se nalazila šalica (PN 363) (T. 3: 1) zaobljenoga tijela i blago udubljenoga dna te s visokom ručkom trakastoga presjeka koja prelazi preko ruba posude.

\section{Lonac}

Usporedbe za lonac u funkciji urne iz groba 37 (T. 2: 3) poznate su iz same Batine, vjerojatno iz jednoga od uništenih paljevinskih grobova. Sačuvan je lonac s bikoničnim tijelom i višim stožastim vratom koji prelazi u ljevkasto izvučeni rub. Na donjem dijelu, na četiri nasuprot postavljena mjesta, nalaze se jezičaste drške koje su okrenute prema dolje (Metzner-Nebelsick 2002: 596, T. 2: 1). S druge strane, lonac grave with a loop fibula (Dobiat 1980: PI. 17: 4).

Comparisons have shown that the graves of the Sopron - Várhely cemetery, but also the Fischau am Steinfeld cemetery, contained a much larger number of glass beads decorated with eye motifs, even of different types, which is recognisably different from grave 36 from Batina and the tumuli from Pécs - Jakabhegy, with only isolated finds of beads. It is assumed that the Sopron beads were imported through trade (Patek 1982b: 161), with the remark that they are absent from some contemporary cemeteries in western Hungary and that they are most numerous at the sites around Sopron (Patek 1982b: 162-166, 173, 175). The most frequent ones are the small monochromatic beads and the blue beads with yellow eye motifs, which are considered to be the most frequent forms in the sphere of the eastern Hallstatt culture (Patek 1982b: 174).

On the basis of a pot type appearing from the southeast Alpine area (Frög, Klein Klein) to the middle Danube and a glass bead, grave 36 can be dated to horizon Illa according to C. Metzner-Nebelsick (2002: 169-172, Fig. 74: 1) or phase Ha Cla according to Ch. Pare (1999: 347, Fig. 27: 10; Tab. 4).

\section{GRAVE 37}

Grave 37 (SU 144/145), with dark brown fill (10YR 4/6), is located in Trench 2 (Figs. 3-4). The rectangular grave pit with rounded corners measures $1.41 \times 0.95 \mathrm{~m}$, with a relative depth of $0.36 \mathrm{~m}$ and vertical sides. In the north-western part of the grave pit there was a large pot (SF 292) (PI. 2: 3) with the cremated bones of an elder adult (S 157; S 200). The pot has a biconical body and tanged handles in four opposing places right under the transition from the shoulder to the lower body. The junction between the shoulder and the short funnel-shaped neck has a horizontal relief strip with fingerprints. Next to the pot, in the north-east corner of the grave, there is a layer of burnt remains with cremated human bones (S 154) which included a bronze profiled tip of a multi-head pin (SF 293) (PI. 2: 1) and a glass bead (SF 371) (PI. 2: 2) on its southern edge. Animal bones - the remains of the shoulder blades of two cows - were laid along the eastern edge of the grave (S 155) (Fig. 4). The south-western part of the grave contained a kantharos (SF 290) (PI. 3: 2) with a biconical body and conical shoulder, decorated with a horizontal series of circular depressions above a decoration organised into metopes, each consisting of four circular depressions alternating with a shaft made of vertical fluting. The handles are slightly wider along the edges and reach above the rim of the vessel. East of the kantharos there was a pot (SF 291) with a biconical body and short cylindrical neck (PI. 3: 3a-b). The juncture of neck and shoulder has a horizontal relief strip; in three places on the shoulder below the strip, there is a relief decoration in the shape of a vertical strip that diverges and ends with a spiral coil on each side. The vertical part of the strip and a part of the spirals, after the divergence, is additionally decorated with oblique incisions. The pot contained a cup (SF 363) (PI. 3: 1) with a spherical body, slightly depressed bottom, and tall handle with strap cross-section rising above the rim of the vessel. 


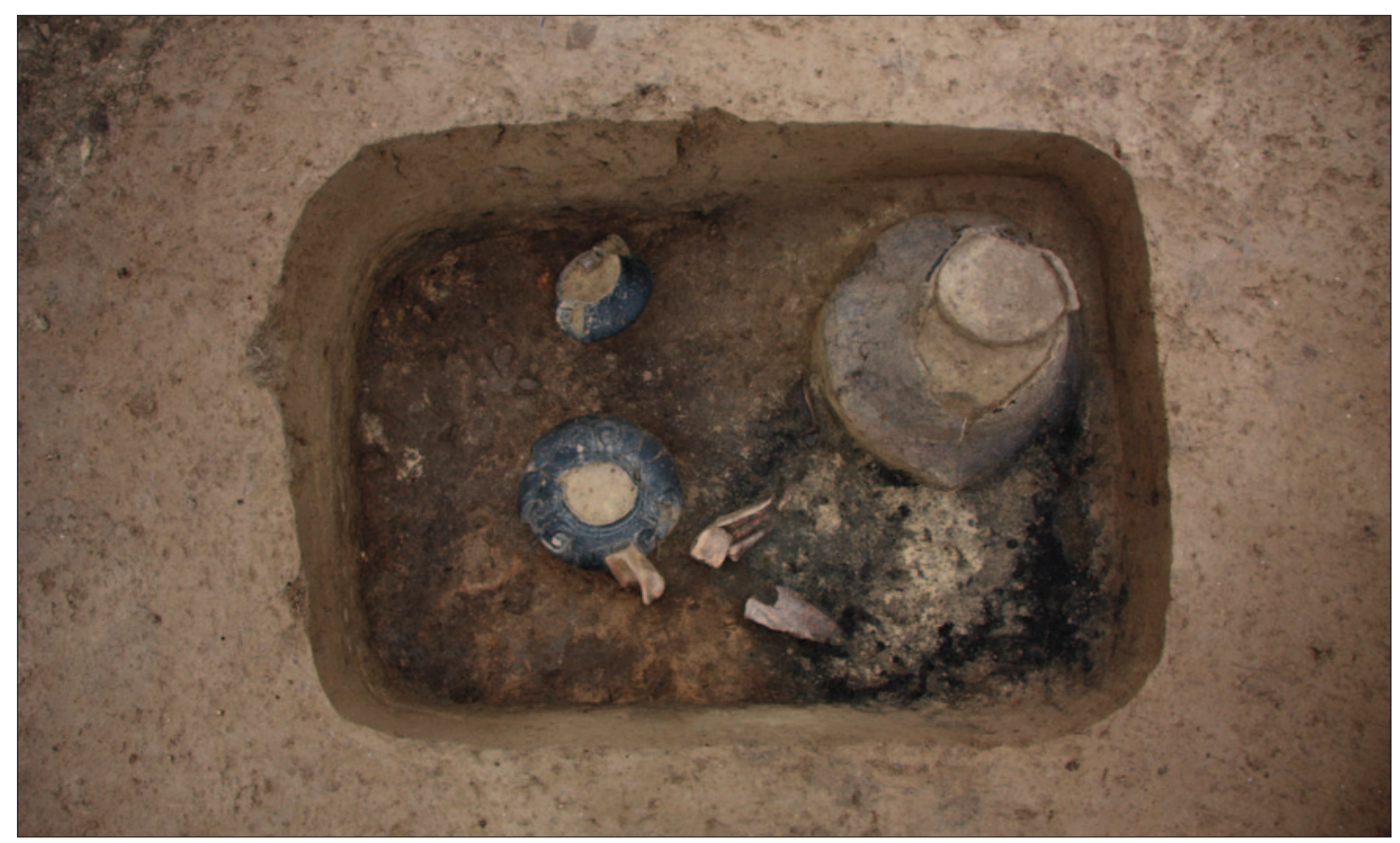

SI. 3 Grob 37 (snimio: V. Mesarić)

Fig. 3 Grave 37 (photo: V. Mesarić)

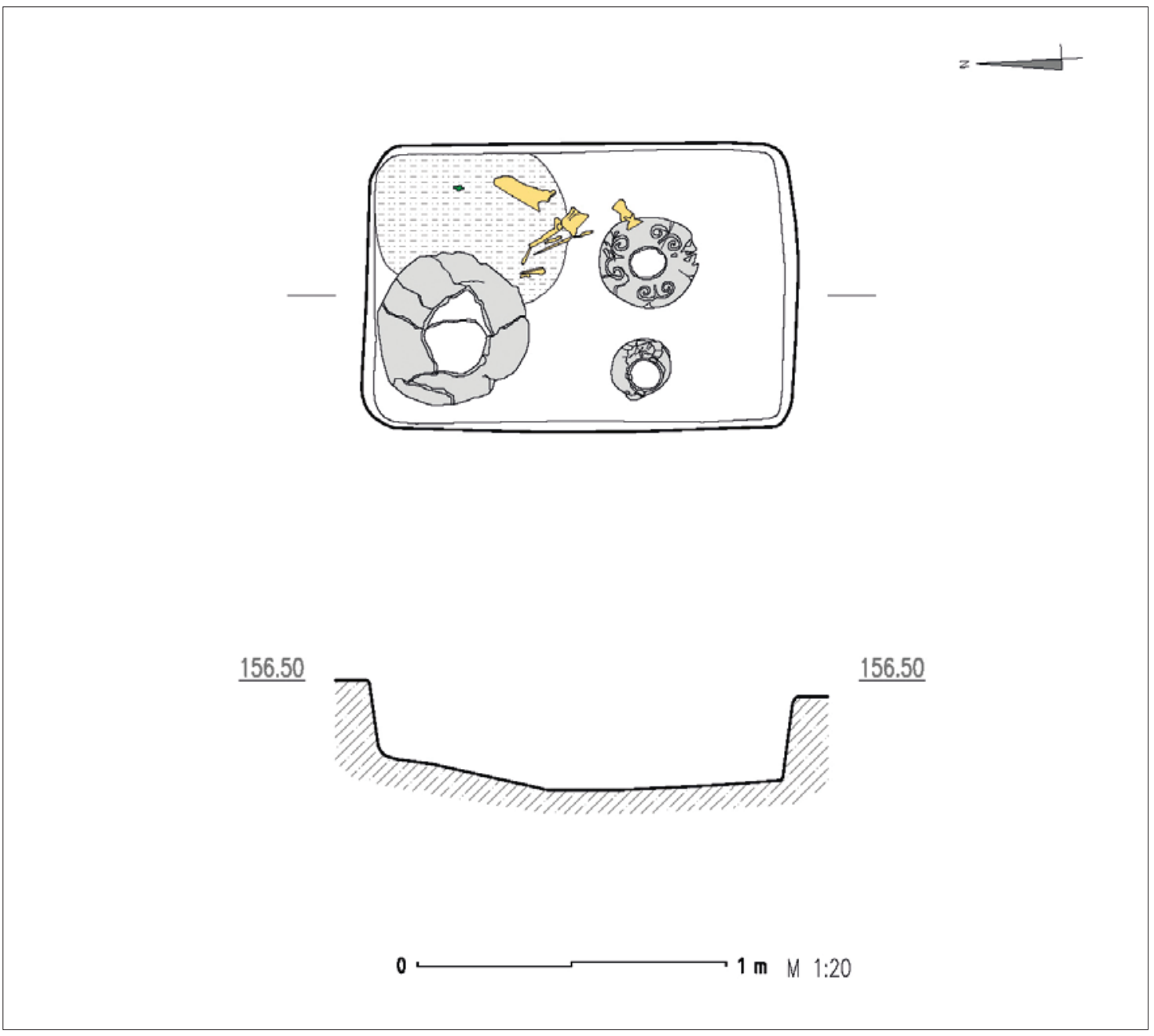

Sl. 4 Grob 37 (crtež: D. Radman; priredio: Arheoplan d.o.o.)

Fig. 4 Grave 37 (drawing: D. Radman; preparation: Arheoplan Ltd.) 
iz groba koji je pronađen na položaju vikendice Matej, a datiran je u horizont Illb, ima znatno šire nisko bikonično tijelo na kojem su također četiri jezičaste drške (sl. 7: 3). U grobu je pronađen i lonac koji je ukrašen $s$ vodoravnim i okomitim plastičnim trakama s otiscima (Metzner-Nebelsick 2002: 175, T. 46: 5), slično drugome loncu iz groba 37. S obzirom da se radi o loncima velikih dimenzija, iz Batine nedostaje veći broj usporedbi za opisani oblik, budući da vjerojatno nisu bili prikupljani tijekom iskopavanja početkom 20. stoljeća. Radi se, dakle, o keramičkome obliku koji je karakterističan za keramičke horizonte IV i V, pri čemu se početak razvoja ovoga oblika vjerojatno može pratiti već od horizonta Illb (Metzner-Nebelsick 2002: 114-118, 174-175, sl. 42; 76: 3; 77: 2).

S groblja Dalj - Busija lonac opisanoga oblika pronađen je u grobu 11/1910 na položaju vinograda Jelenik. Lonac ima nešto viši donji dio tijela na kojemu se također nalaze plastične drške okrenute prema dolje (Hoffiller 1938: 3, T. 2: 4). Lonac iz groba 10/1909 iz vinograda Panišić također ima nešto viši donji dio bikoničnoga tijela s jezičastim drškama. Grob je nalazima fibula datiran u keramički horizont Illb, a u njemu su pronađene brončana dvopetljasta fibula s nogom u obliku beotskoga štita te brončana dvopetljasta fibula tipa Batina (Hoffiller 1938: 2, T. 1: 6; Metzner-Nebelsick 2002: 667, T. 66: 9). Fibule ukazuju na Ha C2, odnosno horizont IV. Zanimljiv je lonac iz groba 9/1911 s položaja Panišić koji je datiran u horizont IV (Hoffiller 1938: 2, T. 1: 3; Metzner-Nebelsick 2002: 177, 667, T. 67: 4). Lonac ima široko bikonično tijelo te široki stožasti vrat koji prelazi u kratki ljevkasto izvučeni rub, dok su na donjem dijelu četiri jezičaste drške.

Možda najsličniji loncu iz groba 37 je lonac iz groba iz ulice V. Nazora 18 u Sotinu (Metzner-Nebelsick 2002: 691, T. 108: 14). Zanimljivo, grob je datiran u horizont $\mathrm{V}$ (MetznerNebelsick 2002: 178).

Dosadašnji rezultati istraživanja u Batini pokazuju kako se razvoj lonaca s visokim stožastim vratom i četiri nasuprot postavljene jezičaste drške na donjem dijelu tijela može pratiti od grobova iz keramičkoga horizonta Illb. Radi se o većim loncima koji imaju šire i više zaobljeno tijelo, dok bi mlađi oblici, poput lonca iz groba 37, imali tijelo koje je bikoničnoga obrisa. Potvrđuju to i spoznaje s groblja u Doroslovu, gdje se pojava lonaca ovoga oblika datira u početak starijega željeznog doba (Vasić 2008: 339-340, 349). Tako loncu iz groba 37 odgovara onaj iz groba 105 koji ima nisko postavljeni bikonični prijelaz ramena u donji dio tijela na kojem se nalaze četiri jezičaste drške okrenute prema dolje (Trajković 2008: 114, 262/1). Lonac u funkciji urne iz groba 15/1963 također ima nisko postavljeni prijelaz donjega dijela tijela u rame, pri čemu se na prijelazu nalaze četiri jezičaste drške (sl. 8: 4). Na vratu je vodoravno rebro. U grobu je, pored drugih keramičkih oblika, pronađen i lonac koji je ukrašen s plastičnim okomitim trakama (Trajković 2008: 331, 331/1). Lonac iz groba 17/1963, s druge strane, ima tijelo koje je jajolikoga oblika, ali na vratu također ima vodoravnu plastičnu traku te na donjem dijelu četiri jezičaste drške. U grobu se nalazi i zdjela S-profilacije s ljevkasto izvučenim rubom koje su karakterističan oblik keramičkoga horizonta IV (Trajković 2008: 333, 333/1).

\section{Pot}

The pot serving as urn from grave 37 (PI. 2: 3) has parallels in Batina itself, probably from one of the destroyed cremation graves. There is a preserved pot with a biconical body and tall conical neck with funnel-shaped everted rim. It has downturned tanged handles in four opposing places on the lower body (Metzner-Nebelsick 2002: 596, PI. 2: 1). On the other hand, the pot from a grave found at the site of the Matej summer house, dated to horizon IIIb, has a much wider squat biconical body, also with four tanged handles (Fig. 7: 3). The grave also contained a pot decorated with horizontal and vertical relief strips with impressions (MetznerNebelsick 2002: 175, PI. 46: 5), similarly to the other pot from grave 37 . As these are large pots, there are not many parallels for this form in Batina, since they were probably not collected during the excavations at the beginning of the $20^{\text {th }}$ century. It is, therefore, a ceramic form that is characteristic for ceramic horizons IV and V, but the beginning of the development of this form can probably be followed from horizon Illb already (Metzner-Nebelsick 2002: 114-118, 174-175, Fig. $42 ; 76: 3 ; 77: 2)$.

A pot with this shape in the Dalj - Busija cemetery was found in grave 11/1910 at the Jelenik vineyard site. The pot has a slightly taller upper body, which also has downturned relief handles (Hoffiller 1938: 3, PI. 2: 4). The pot from grave 10/1909 from the Panišić vineyard also has a slightly taller lower part of the biconical body with tanged handles. On the basis of the fibulae found inside the grave - a bronze a double-looped fibula with catch-plates in the form of a Boeotian shield and a bronze two-looped fibula of the Batina type - the grave was dated to ceramic horizon IIIb (Hoffiller 1938: 2, PI. 1: 6; Metzner-Nebelsick 2002: 667, PI. 66: 9). The fibulae indicate $\mathrm{Ha}$ C2 or horizon IV. An interesting pot from grave 9/1911 at the Panišić site was dated to horizon IV (Hoffiller 1938: 2, PI. 1: 3; Metzner-Nebelsick 2002: 177, 667, PI. 67: 4). The pot has a wide biconical body and wide conical neck merging into a short funnel-shaped everted rim, while the lower body has four tanged handles.

The pot from grave 37 has its most similar parallel in the pot from the grave at the address V. Nazora 18 in Sotin (Metzner-Nebelsick 2002: 691, PI. 108: 14). Interestingly, this grave was dated to horizon V (Metzner-Nebelsick 2002: 178).

The results of the excavations in Batina show that the development of pots with tall conical neck and four opposing tanged handles on the lower body can be followed starting from the graves of ceramic horizon Illb. They are large pots with wider and taller spherical body, while the younger forms, such as the pot from grave 37 , have a biconical body. This is confirmed by the discoveries at the Doroslovo cemetery, where the appearance of this form of pots was dated to the beginning of the Early Iron Age (Vasić 2008: 339-340, 349). The pot from grave 37 has a parallel in the pot from grave 105 which has a low-set biconical junction of shoulder and lower body with four downturned tanged handles (Trajković 2008: 114, 262/1). The pot serving as urn from grave 15/1963 also has a low-set junction of lower body and shoulder with four tanged handles (Fig. 8: 4). The neck has a horizontal rib. Aside from other ceramic forms, the grave contained a pot decorated with vertical relief strips (Trajković 2008: 331, 331/1). The pot from grave 
Iz Doroslova su zanimljivi i lonci, položeni u funkciji urne, sa širokim tijelom i plastičnom trakom s otiscima koja se nalazi na prijelazu vrata u rame, dok se na donjem, izuzetno širokom dijelu, na četiri nasuprot postavljena mjesta, nalaze jezičaste drške okrenute prema dolje. Opisani je oblik poznat iz dvojnoga groba 7 (Trajković 2008: 31, 185/1) te iz bogatoga ženskog groba 123 (Trajković 2008: 129, 278/1). Istoga je oblika i lonac u funkciji urne iz bogatoga groba 147 (Trajković 2008: 165, 314/1), no posebno je značajan lonac iz bogatoga groba 141 (Fig. 9: 1) s dvopetljastom lučnom fibulom s nožicom u obliku beotskoga štita (Trajković 2008: 163, 306/1) koji je datiran u horizont IV (Metzner-Nebelsick 2002: 109-110, sl. 39). Zanimljivo, spomenuti grob 10/1909 iz Dalja s položaja vinograda Panišić, s istim oblikom fibule, datiran je u horizont Illlb.

Na osnovi usporedbi, lonac iz groba 37 svojim karakterističnim obrisom vjerojatno predstavlja najmlađi razvojni oblik lonaca s visokim stožastim vratom te s četiri jezičaste drške na donjem dijelu tijela na groblju u Batini. Pojava ovoga oblika za sada se može slijediti od keramičkoga horizonta Illb te se, uz određene oblikovne promjene, nastavlja do kraja razvoja daljske grupe.

\section{Lonac s plastičnim spiralama}

U grobu 37 pronađen je još jedan lonac bikoničnoga tijela i kratkoga cilindričnog vrata koji je bogato ukrašen $s$ raznoliko organiziranim plastičnim trakama (T. 3: 3a-b). Sličan je lonac u Batini pronađen u grobu na položaju vikendice Matej (sl. 7: 4) koji je datiran u keramički horizont Illb (Metzner-Nebelsick 2002: 174-175). Lonac ima niski cilindrični vrat na kojem su, kao i na vrhu ramena, četiri vodoravne plastične trake s otiscima. Na ramenu, na četiri nasuprot postavljena mjesta, nalazi se okomita plastična traka s otiscima koja se dijeli i završava u spirali sa svake strane. Između plastičnih ukrasa, također na ramenu, nalaze se motivi rozete koja se sastoji od većega središnjeg okruglog udubljenja oko kojega su raspoređena ona manja (Metzner-Nebelsick 2002: 649, T. 46: 4). U grobu 15/1963 iz Doroslova pronađen je lonac s kratkim ljevkastim vratom te bikoničnoga tijela (sl. 8: 5) koji na vrhu ramena ima vodoravno plastično rebro ispod kojega se, na četiri nasuprot postavljena mjesta, nalazi ukras od tri okomito postavljene plastične trake od kojih su rubne u donjem dijelu uvijene prema van (Trajković 2008: 332, 332/5). Grob je datiran u kraj 7. i 6. st. pr. Kr. (Vasić 2008: 349).

Sličan lonac pronađen je u Slatini, na groblju Berezine, u dvojnome grobu datiranom u Illb horizont (Ložnjak Dizdar 2015: 30-31, 36, T. 1: 1). Lonac ima žljebljene ukrase u obliku girlande. Slični lonci u velikome broju pojavljuju se na groblju Nova Tabla u sjeveroistočnoj Sloveniji te su izdvojeni kao tip lonca L2.2 (Guštin et al. 2017: 93, sl. 49: L.2.2). Takvi lonci pojavljuju se već u najstarijoj skupini grobova, npr. grobovi 67 i 90 (Guštin et al. 2017: 98, 488, grob 67, 1616; grob 90, 1782). Lonci sličnoga oblika česti su na groblju Kleinklein gdje se pojavljuju od 1. Faze, no osobito su brojni u mlađim fazama trajanja groblja (Dobiat 1980: 93-94, sl. 10: 16). Takav oblici lonaca pronađeni su u tumulu $1 \mathrm{u} \mathrm{Za-}$
$17 / 1963$, on the other hand, has an egg-shaped body, but it also has a horizontal relief strip on the neck and four tanged handles on the lower body. The grave also included an Sprofiled bowl with a funnel-shaped everted rim, which is a characteristic form of ceramic horizon IV (Trajković 2008: $333,333 / 1)$.

The interesting finds at Doroslovo include the pots serving as urns, with a wide body and a relief strip with impressions on the junction of neck and shoulder, while the lower body, which is exceptionally wide, has downturned tanged handles in four opposing places. This form is known from double grave 7 (Trajković 2008: 31, 185/1) and rich woman's grave 123 (Trajković 2008: 129, 278/1). The pot serving as urn from rich grave 147 has the same form (Trajković 2008: 165, $314 / 1$ ), but a particularly important pot is the one from rich grave 141 (Fig. 9: 1) with a double-looped fibula with catchplates in the form of a Boeotian shield (Trajković 2008: 163, 306/1), dated to horizon IV (Metzner-Nebelsick 2002: 109-110, Fig. 39). Curiously, a grave we already mentioned - 10/1909 from the Panišić vineyard site in Dalj - with the same form of fibula - was dated to horizon Illb.

On the basis of comparisons, the characteristic shape of the pot from grave 37 makes it probably the youngest development form of the pots with tall conical neck and four tanged handles on lower body at the Batina cemetery. Currently, the appearance of this form can be followed starting from ceramic horizon IIlb, and continues, with changes in form, until the end of the development of the Dalj group.

\section{Pot with relief spirals}

Grave 37 contained another pot with biconical body and short cylindrical neck, richly decorated with variously organised relief strips (PI. 3: 3a-b). A similar pot in Batina was found in a grave at the Matej summer house site (Fig. 7: 4) and dated to ceramic horizon IIIb (Metzner-Nebelsick 2002: 174-175). The pot has a low cylindrical neck; both the neck and the top of the shoulder have four horizontal relief strips with impressions. In four opposing places on the shoulder there is a vertical relief strip with impressions that diverges and ends with a spiral on each side. Between the relief decorations, which are also on the shoulder, there are motifs of a rosette consisting of a large central circular depression surrounded by smaller ones (Metzner-Nebelsick 2002: 649, PI. 46: 4). Grave 15/1963 from Doroslovo contained a pot with short funnel-shaped neck and biconical body (Fig. 8: 5) which has a horizontal relief rib at the top of the shoulder and, in four opposing places under it, a decoration of three vertical relief strips, where the edge strips are curled outwards in the lower part (Trajković 2008: 332, 332/5). The grave was dated to the end of the $7^{\text {th }}$ and the $6^{\text {th }}$ century $B C$ (Vasić 2008: 349).

A similar pot was found at the Berezine cemetery in Slatina, in a double grave dated to horizon Illb (Ložnjak Dizdar 2015: 30-31, 36, PI. 1: 1). The pot has groove decorations in the shape of a garland. Numerous similar pots were found at the Nova Tabla cemetery in north-eastern Slovenia and isolated as pot type L2.2 (Guštin et al. 2017: 93, Fig. 49: L.2.2). These pots appear in the oldest group of graves already, e.g. graves 67 i 90 (Guštin et al. 2017: 98, 488, grave 67, 1616; 
gersdorfu (Gradišće) gdje su bili ukrašeni crvenim i crnim slikanjem, pri čemu su u jednoj od tih posuda pronađene koštice grožda što je izravan dokaz kako je lonac sadržavao vino te je bio dio simpozijalnoga servisa u grobu (Rebay 2002: $42-43,80$, T. 18-20; 21; 1). Velik broj takvih posuda pojavljuje se i na groblju Maiersch u Donjoj Austriji datiranom od 8. do početka 6. st. pr. Kr. (Berg 1962: T. 1: 2; T. 6: 1; 15: 5, 7; 16 : 4; 17: 2; 18: 8; 19: 2; 31: 10-11; 36: 3-12). Važno je spomenuti kako $C$. Dobiat naglašava da je ovakav oblik tipičan za sjeveroistočnoalpski prostor, pri čemu groblja u dolini Sulma te Frög u Koruškoj predstavljaju najjužnije nalaze (Dobiat 1980: 94). C. Metzner Nebelsick je u objavi 2002. godine već dokazala kako se ovi lonci pojavljuju i jugoistočnije (2002: sl. 41). Lonci s nižim koničnim vratom iz Batine i Doroslova, koji su korišteni kao urne, mogu predstavljati oblik koji prethodi loncima s kuglastim tijelom i niskim koničnim vratom (Kragenrandgefäß), često bogato ukrašenima s raznolikim motivima i tehnikama, a koji su najbrojniji između Balatona i rijeke Save te su datirani u keramički horizont IV (MetznerNebelsick 2002: 112-114, sl. 41; 2017b: 433, sl. 1). Ista autorica razlikuje i drugi tip lonca tzv. squat između Keglehalsgefäß i Kragenrandgefäß (Metzner-Nebelsick 2017b: 433). Zbog toga smo lonac iz groba $37 \mathrm{~s}$ niskim vratom skloniji svrstati u tip Kragenrandgefäß, budući da je, na osnovi usporedbi s nalazima iz Podravine i Prekmurja, ovaj lonac nasličniji navedenome obliku te je malo stariji od lonca koji se pojavljuje u grobu 141 u Doroslovu.

Kombinacija sličnoga lonca u funkciji urne i lonca $s$ niskom vratom pronađena je u već spomenutome grobu 141 u Doroslovu (sl. 9: 1, 4) u kojem je, uz bogate druge priloge, pronađena i fibula s nožicom u obliku beotskoge štita (Trajković 2008: 163, 306-308). Lonac s niskim vratom u ovome grobu ima razvijeniji oblik, zatim naglašeni bikonitet $i$ rame posude te rub izvijen prema van (sl. 9: 4). S obzirom na malobrojne izravne usporedbe, lonac iz groba 37 u Batini vjerojatno se, kao i ostali nalazi u grobu, može pripisati keramičkome horizontu IIllb ili početku horizonta IV prema C. Metzner Nebelsick (2002: 173-175, sl. 75; 76: 8). Isto tako, potrebno je istaknuti i lokalni motiv ukrasa dvostruke plastične spirale na loncu iz groba 37 kakav je već zabilježen u Batini tijekom starijega željeznog doba (Metzner-Nebelsick 2002: sl. 68: 4/II/5).

\section{Kantharos}

U jugozapadnome dijelu groba pronađen je kantharos bikoničnoga tijela i stožastoga ramena koji je ukrašen s vodoravnim nizom kružnih udubljenja ispod kojih se nalazi metopno organizirani ukras sastavljen od po četiri kružna udubljenja koja se izmjenjuju sa skupinama okomito postavljenih kanelura. Ručke su trakastoga presjeka, blago zadebljane uz rubove te prelaze preko ruba posude (T. 3: 2).

Kantharosi poput opisanoga smatraju se karakterističnim oblikom za keramičke horizonte IIIb i IV (Metzner-Nebelsick 2002: 125, 174-175, sl. 75: 9; 76: 5), pri čemu je posebno zanimljiva metopna organizacija ukrasa na ramenu kantharosa iznad koje se još nalazi vodoravni niz udubljenja.

Sličan je kantharos s vodoravnim nizom kružnih udubljenja na ramenu ispod kojega su okomite uske kanelure grave 90,1782$)$. Pots with a similar form are frequent at the Kleinklein cemetery, where they first appear in Phase 1, but they are particularly numerous in the younger phases of the cemetery (Dobiat 1980: 93-94, Fig. 10: 16). This form of pots was found in tumulus 1 in Zagersdorf (Burgenland), where they were decorated with red and black painting; one of the vessels contained grape seeds, which is the direct proof that the pot used to hold wine as an item of a symposium set in the grave (Rebay 2002: 42-43, 80, Pls. 18-20; 21: 1). A large number of such vessels were found at the Maiersch cemetery in Lower Austria, dated from the $8^{\text {th }}$ to the beginning of the $6^{\text {th }}$ century BC (Berg 1962: PI. 1: $2 ; 6: 1 ; 15: 5,7$; $16: 4 ; 17: 2 ; 18: 8 ; 19: 2 ; 31: 10-11 ; 36: 3-12)$. It is important to note that $C$. Dobiat points out that this form is typical for the north-eastern Alpine area, with the southernmost finds in the cemeteries in the Sulm valley and in Frög in Carinthia (Dobiat 1980: 94). In a paper from 2002, C. Metzner Nebelsick proved that these pots appear even further south-east (2002: Fig. 41). Pots with a lower conical neck from Batina and Doroslovo, which served as urns, can represent the form that precedes the pots with spherical body and low conical neck (Kragenrandgefäß), often richly decorated with different motifs and techniques, which are most numerous between Balaton and the River Sava, and dated to ceramic horizon IV (Metzner-Nebelsick 2002: 112-114, Fig. 41; 2017b: 433, Fig. 1). The same author differentiates another type of pot, the squat, between Keglehalsgefäß and Kragenrandgefäß (Metzner-Nebelsick 2017b: 433). For this reason, we prefer to classify the pot from grave 37 with a low neck into the Kragenrandgefäß type, since the comparisons with the finds from Podravina and Prekmurje show that this pot is the closest to this form and slightly older than the pot from grave 141 at Doroslovo.

A combination of a similar pot serving as urn and a pot with low neck was found in the mentioned grave 141 in Doroslovo (Fig. 9: 1, 4), which contained various rich grave goods including a double-looped fibula with catch-plates in the form of a Boeotian shield (Trajković 2008: 163, 306308). The pot with low neck in this grave has a more developed form, a pronounced biconical shape and shoulder, and an everted rim (Fig. 9: 4). Considering the few direct parallels, the pot from grave 37 in Batina, just like the other finds in that grave, can probably be associated with ceramic horizon IIIb or the beginning of horizon IV according to $C$. Metzner Nebelsick (2002: 173-175, Fig. 75; 76: 8). Moreover, we should point out the local decoration motif of double relief spiral on the pot from grave 37, which was already present in Batina in the Early Iron Age (Metzner-Nebelsick 2002: Fig. 68: 4/II/5).

\section{Kantharos}

The south-western part of the grave contained a kantharos with biconical body and conical shoulder, decorated with a horizontal series of circular depressions above a decoration organised into metopes, each consisting of four circular depressions alternating with groups of vertical fluting. The handles of strap cross-section are slightly wider along the edges, and reach above the rim of the vessel (PI. 3: 2).

Kantharoi like the one above are considered a characteristic form of ceramic horizons IIllb and IV (Metzner-Nebelsick 
pronađen u grobu 29/1910 u Dalju na položaju vinograda Pavošević. U grobu se nalazio još jedan kantharos, a grob je datiran u keramički horizont Illb (Hoffiller 1938: 6, T. 13: 5; Metzner-Nebelsick 2002: T. 71: 3). U već spomenutome grobu 10/1909 s položaja Panišić također su se nalazila dva kantharosa. Jedan je ukrašen s nizom kružnih udubljenja na ramenu, dok je drugi ukrašen metopno organiziranim ukrasom gdje se izmjenjuje po jedno kružno udubljenje s okomito postavljenim kanelurama (Hoffiller 1938: 6, T. 13: 7, 9; Metzner-Nebelsick 2002: T. 66: 10-11). U grobu su pronađene fibula s nožicom u obliku beotskoga štita te fibula tipa Batina, odnosno grob je pripisan horizontu Illb (MetznerNebelscik 2002: 175, 415). Sličan drugome kantharosu iz groba u Dalju je kantharos iz groba 1 u Doroslovu. Ispod ručki još se nalaze po dva kružna udubljenja (Trajković 2008: 25, 179/4). Najsličnije ukrašeni kantharos pronađen je u grobu 136 u Doroslovu, pri čemu se izmjenjuju dva ili tri kružna udubljenja s okomitim kanelurama (Trajković 2008: 143, 297/4). Na groblju u Doroslovu pronađen je veći broj slično, metopno ukrašenih kantharosa, gdje se izmjenjuju kružna udubljenja s okomitim ili kosim te uskim kanelurama. ${ }^{10}$ Grobovi iz Doroslova s opisanim kantharosima također se mogu datirati u keramičke horizonte IIIb-IV, a zabilježeni su kako u muškim, tako i u ženskim grobovima. Velik broj kantharosa pronađenih u Doroslovu, uostalom kao i u Batini, pokazuje kako se radi o važnome keramičkom recipijentu koji je vjerojatno imao i neko simbolično značenje u grobnome ritualu (Metzner-Nebelsick 2002: 125, 128; Ložnjak Dizdar 2011: 251, karta 3). U Doroslovu je najčešće zabilježen prilog po jednoga kantharosa, no ima i grobova s dva, pa čak i tri kantharosa koji su različitih veličina (npr. grob 134), pri čemu je pojava kantharosa u grobovima datirana od Ha B3 (Vasić 2008: 340-341, 347, 349). Kantharosi su bili rasprostranjeni uglavnom na Balkanu i južnome dijelu srednjega Podunavlja odakle su tijekom starijega željeznog doba rasprostranjeni kao ideja prema zapadu (Metzner-Nebelsick 2002: 127, sl. 47). Isto tako, kombinacija ukrasa koja se pojavljuje na kantharosu iz groba 37 pripada plastičnim ukrasima koji su vrlo uobičajeni na groblju u Doroslovu (Metzner-Nebelsick 2002: sl. 71: $4 \mathrm{l} / 40)$.

\section{Šalica}

U loncu ukrašenome s plastičnim ukrasima nalazila se šalica zaobljenoga tijela i blago udubljenoga dna te s visokom ručkom trakastoga presjeka koja prelazi preko ruba posude (T. 3: 1). Šalice opisanoga oblika već su poznate iz Batine (Metzner-Nebelsick 2002: 614, T. 22: 9; 648, T. 45: 14), dok jedna slična šalica ima ručku okrugloga presjeka (Metzner-Nebelsick 2002: 608, T. 16: 10). Ovakve su šalice poznate i s groblja u Dalju (Hoffiller 1938: 11, T. 23: 4, 10, 12; Metzner-Nebelsick 2002: T. 48: 5; 55: 7, 11; 64: 7-8; 71: 10; 81: 1) te iz grobova u Donjem gradu u Osijeku gdje šalice, ipak, imaju nešto niže trakaste ručke (Šimić 2001: 33, sl. 16).

10 Grob 2 (Trajković 2008: 26, 180/4); grob 17, gdje se ispod ručki nalaze kanelure (Trajković 2008: 43, 196/9); grob 26 s kantharosom gdje se na ramenu izmjenjuju po dva udubljenja sa skupinama okomitih kanelura, dok su ispod ručki po dva udubljenja (Trajković 2008: 50-51, 203/3); grob $27 \mathrm{~s}$ kantharosom gdje se izmjenjuju po tri udubljenja s okomitim kanelurama (Trajković 2008: 52, 206/7) itd.
2002: 125, 174-175, Fig. 75: 9; 76: 5), with a particularly interesting metope organisation of decorations on the shoulder of the kantharos and a horizontal series of depressions above it.

A similar kantharos with a horizontal series of circular depressions on the shoulder above narrow vertical flutes was found in grave 29/1910 in Dalj, at the Pavošević vineyard site. The grave, which included another kantharos, was dated to ceramic horizon IIIb (Hoffiller 1938: 6, PI. 13: 5; Metzner-Nebelsick 2002: PI. 71: 3). The mentioned grave 10/1909 at the Panišić site also contained two kantharoi. One is decorated with a series of circular depressions on the shoulder, while the other is decorated with a decoration organised into metopes, where single circular depressions alternate with vertical fluting (Hoffiller 1938: 6, PI. 13: 7, 9; Metzner-Nebelsick 2002: Pl. 66: 10-11). The grave, which contained a double-looped fibula with catch-plates in the form of a Boeotian shield and a fibula of the Batina type, was associated with horizon IIllb (Metzner-Nebelscik 2002: $175,415)$. A kantharos that is similar to the one from the grave in Dalj is the kantharos from grave 1 in Doroslovo. It has two additional circular depressions under the handles (Trajković 2008: 25, 179/4). The kantharos with the most similar decorations was found in grave 136 in Doroslovo, alternating two or three circular depressions with vertical fluting (Trajković 2008: 143, 297/4). The Doroslovo cemetery contained a large number of similarly metope-decorated kantharoi, alternating circular depressions with narrow vertical or oblique fluting. ${ }^{10}$ The graves from Doroslovo with these kantharoi can also be dated to ceramic horizons IllbIV, and have been found both in men's and women's graves. The large number of kantharoi found in Doroslovo, but also in Batina, shows that it was an important ceramic recipient which probably also had a symbolic meaning in the funerary rite (Metzner-Nebelsick 2002: 125, 128; Ložnjak Dizdar 2011: 251, Map 3). In Doroslovo, kantharoi as grave goods are most frequent when single, but there are graves with two or even three kantharoi of different sizes (e.g. grave 134), with the first appearance of kantharoi in graves dated to Ha B3 (Vasić 2008: 340-341, 347, 349). Kantharoi were common mostly in the Balkans and the southern part of the middle Danube, but this concept spread westwards in the Early Iron Age (Metzner-Nebelsick 2002: 127, Fig. 47). Also, the combination of decorations appearing on the kantharos from grave 37 belongs to the relief decorations that are very frequent at the Doroslovo cemetery (Metzner-Nebelsick 2002: Fig. 71: $4 \mathrm{I} / 40$ ).

\section{Cup}

The pot decorated with relief decorations contained a cup with spherical body and slightly depressed bottom and a tall handle of strap cross-section reaching above the rim of the vessel (PI. 3: 1). Cups of this form are already known from Batina (Metzner-Nebelsick 2002: 614, PI. 22: 9; 648, Pl. 45: 14), while a similar cup has a handle of circular cross-

10 Grave 2 (Trajković 2008: 26, 180/4); grave 17, with fluting under the handles (Trajković 2008: 43, 196/9); grave 26 has a kantharos with groups of two depressions alternating with groups of vertical fluting on the shoulder and with two depressions under each handle (Trajković 2008: 50-51,203/3); grave 27 has a kantharos with groups of three depressions alternating with vertical fluting (Trajković 2008: 52, 206/7) etc. 
Šalice zaobljenoga tijela pronađene su i na groblju Lijeva bara u Vukovaru (Vinski-Gasparini 1973: 160, T. 122: 13; 124: 3; Metzner-Nebelsick 2002: 692, T. 110: 5; 111: 8).

Na groblju u Doroslovu također je zabilježena pojava šalica koničnoga ili zaobljenog tijela, s ručkom koja najčešće prelazi preko ruba, a datirane su u starije željezno doba (Vasić 2008: 341, 349; Brukner 1959: 14-15, sl. 19). Ručke su najčešće trakastoga presjeka, no ima i onih koje su tordirane, npr. u grobu 6 (Trajković 2008: 29-30, 183/3, 184/14). U grobovima se najčešće nalazi po jedna šalica, no ima i grobova s dvije (npr. grobovi 33, 110, 123, 142) ili tri šalice (npr. grob 7), pri čemu se tada može raditi i o grobovima s dva pokojnika.

\section{Brončani završetak višeglave igle}

U sjeveroistočnome uglu grobne rake nalazio se sloj paljevine sa spaljenim kostima, na čijem je južnome rubu pronađen brončani profilirani završetak višeglave igle (T. 2: 1). Sama igla nije pronađena.

Iz Batine su od ranije poznati nalazi višeglavih igli s prstenastim zadebljanjem (Metzner-Nebelsick 2002: 109, 603, T. 9: 7; 642, T. 39: 3; Nađ, Nađ 1964: 15, T. XV: 5) koje su datirane u horizont IIlb, s mogućnošću kako se pojavljuju i malo kasnije, a promatrane su kao dio muške nošnje (Metzner-Nebesick 2002: 428-429, sl. 191). Višeglave igle s ovalnim i prstenastim zadebljanjima te trubljastim završetkom poznate su i s groblja u Dalju. Na krajevima dvije sačuvane igle nalazi se profilirani završetak poput onoga iz groba 37 sa zaobljenim središnjim dijelom, dok su na krajevima prstenasta zadebljanja (Vinski, Vinski-Gasparini 1962: 270, T. VII: 82; Vinski-Gasparini 1973: 163, T. 120: 7). Radi se o najmlađem obliku brončanih višeglavih igli (Metzner-Nebelsick 2002: 109, 113-114, 669, T. 73: 1-3), pri čemu iz Dalja potječe još nekoliko nalaza (Metzner-Nebelsick 2002: 674, T. 90: 14; 678, T. 100: 31-32). Na groblju u Doroslovu ulomak brončane višeglave igle pronađen je u grobu 119 (Trajković 2008: 127, 276/13) s keramičkim oblicima koji bi ukazivali na keramički horizont IV.

Brončani profilirani završetak igle, sa širokim ovalnim zadebljanjem, pronađen je u grobu u kneževskome tumulu 1 u Somlóvásárhelyu. Grob je datiran u Ha C1, odnosno u kraj 8. i prvu polovicu 7. st. pr. Kr. (Egg 1998: 348-350, 352, sl. 3: 11; 16: 1; Patek 1993: 70, 123, sl. 57: 1). S druge strane, isti je tumul datiran u Ha C2, odnosno u stupanj Štajerska III koji je istovremen horizontu Stična - Novo Mesto u Dolenjskoj (Teržan 1990: 157, 163; Stegmann-Rajtár 1993: 100, sl. 36: 2). U muškim grobovima u Halstattu takvi završeci igle datirani su u m1C fazu koja odgovara sredini 7. st. pr. Kr (Hodson 1990: 59, sl. 13, Tab. 8).

\section{Staklena perla}

U sloju paljevine u sjeveroistočnome uglu grobne rake, sa spaljenim kostima, pronađena je i mala staklena perla svijetlozelenkaste boje (T. 2: 1).

Staklene su perle zabilježene i na groblju u Doroslovu, no u manjem broju (Vasić 2008: 344). Tako je u grobu 42 također pronađena jedna perla svijetlozelene boje (Trajković 2008: 66, 218/16), dok se u grobu 44 nalazila jedna perla ta- section (Metzner-Nebelsick 2002: 608, Pl. 16: 10). These cups are also known from the Dalj cemetery (Hoffiller 1938: 11, Pl. 23: 4, 10, 12; Metzner-Nebelsick 2002: PI. 48: 5; 55: 7, 11; 64: $7-8 ; 71: 10 ; 81: 1)$ and from the graves in the Lower Town of Osijek, where the cups have lower strap handles, however (Šimić 2001: 33, Fig. 16). Cups with spherical body have also been found at the Lijeva Bara cemetery in Vukovar (VinskiGasparini 1973: 160, PI. 122: 13; 124: 3; Metzner-Nebelsick 2002: 692, PI. 110: 5; 111: 8).

The Doroslovo cemetery also includes cups with conical or spherical body and handle rising above rim, which were dated to the Early Iron Age (Vasić 2008: 341, 349; Brukner 1959: 14-15, Fig. 19). Handles usually have strap cross-section, but some are twisted, e.g. in grave 6 (Trajković 2008: $29-30,183 / 3,184 / 14)$. The graves usually contain a single cup, but there are also graves with two (e.g. graves 33,110 , 123,142 ) or three cups (e.g. grave 7 ), in which case they may be graves with two dead bodies.

\section{Bronze tip of a multi-head pin}

In the north-east corner of the grave pit there was a layer of burnt remains with cremated bones, which included a bronze profiled tip of a multi-head pin (PI. 2: 1) on its southern edge. The pin itself was not found.

There are earlier finds of multi-head pins with ring-like swelling in Batina (Metzner-Nebelsick 2002: 109, 603, PI. 9: 7; 642, PI. 39: 3; Nađ, Nađ 1964: 15, Pl. XV: 5), dated to horizon IIIb with the possibility of appearing somewhat later too, and considered as items of men's costume (Metzner-Nebesick 2002: 428-429, Fig. 191). Multi-head pins with oval and ring-like swelling and trumpet-like tip are also known from the Dalj cemetery. The tips of two preserved pins have a profiled terminal like the one from grave 37 with a rounded central part, while the tips have ring-like swellings (Vinski, Vinski-Gasparini 1962: 270, PI. VII: 82; Vinski-Gasparini 1973: 163, PI. 120: 7). It is the youngest form of bronze multi-head pins (Metzner-Nebelsick 2002: 109, 113-114, 669, PI. 73: 1-3), and there are several more finds from Dalj (Metzner-Nebelsick 2002: 674, PI. 90: 14; 678, PI. 100: 31-32). The Doroslovo cemetery contained a fragment of a bronze multi-head pin in grave 119 (Trajković 2008: 127, 276/13) together with ceramic forms that indicate ceramic horizon IV.

A bronze profiled tip of a pin, with a wide oval swelling, was found in a grave in the princely tumulus 1 in Somlóvásárhely. The grave was dated to $\mathrm{Ha} \mathrm{C} 1$, i.e. to the end of the $8^{\text {th }}$ and the first half of the $7^{\text {th }}$ century BC (Egg 1998: 348-350, 352, Fig. 3: 11; 16: 1; Patek 1993: 70, 123, Fig. 57: 1). On the other hand, the same tumulus was dated to $\mathrm{Ha}$ C2, i.e. to phase Styria III, which is contemporary with horizon Stična - Novo Mesto in Lower Carniola (Teržan 1990: 157, 163; Stegmann-Rajtár 1993: 100, Fig. 36: 2). Such pin tips from the men's graves in Halstatt were dated to phase $\mathrm{m} 1 \mathrm{C}$, which is equivalent to the mid- $7^{\text {th }}$ century BC (Hodson 1990: 59, Fig. 13, Tab. 8).

\section{Glass bead}

In the layer of burnt remains in the north-eastern corner of the grave pit, among cremated bones, there was a small glass bead that is light green in colour (PI. 2: 1).

Glass beads were also recorded at the Doroslovo cemetery, but in smaller numbers (Vasić 2008: 344). For exam- 
mnosive boje (Trajković 2008: 69, 221/18). U starijem grobu 84 pronađena je jedna mala plava perla (Trajković 2008: 98, 246/4), dok su u grobu 128, datiranom u 8. st. pr. Kr., pronađene dvije žute i jedna mrka staklena perla (Trajković 2008: 137, 286/14).

U tumulu 102 na groblju Pécs - Jakabhegy pronađene su male tirkizne i plave staklene perle (Metzner-Nebelsick 2002: 701, T. 121: 20). S druge strane, staklene su perle izuzetno brojne na nalazištima oko Soprona (Patek 1982b: 162$166,173,175)$ gdje se najčešće pojavljuju one male jednobojne te plave perle sa žutim motivima oka koje su najčešće na prostoru istočne halštatske kulture (Patek 1982b: 174), kakve su također poznate iz Batine. Tako je iz grobova pod tumulima na groblju Sopron - Várhely (Burgstall) poznat velik broj malih jednobojnih perli koje su bile dio ogrlice (npr. tumul 177), kakve su pronađene i u zemunici na naselju, dok se za dio nalaza pretpostavlja kako vjerojatno potječe iz uništenih grobova (Patek 1982b: 168, 174, T. III-IV; VI: 1). U tumulu 59 pronađena je perla od svijetloga prozirnog stakla kao i jedna cilindrična žuta, pored onih ukrašenih s motivima oka ili valovnice. Perle pokazuju tragove spaljivanja s pokojnicom (Patek 1982b: 173, T. IX; Eibner-Persy 1980: 51, 164-165, T. 56: 5-6). U tumulu 148 pronađene su perle ukrašene s motivom oka ili valovnice te one male jednobojne žute i plave boje (Patek 1982b: 173, T. VIII; Eibner-Persy 1980: 51, 185, T. 77: 4, 6-7). Na groblju Masser - Kreuzbauer također su pronađene male perle od neprozirnoga žutog stakla, i to u grobovima 1, 12 i 13. Vjerojatno su nošene kao dio ogrlice, no možda su mogle biti i ušivene na odjeći (Bernhard, Weihs 2003: 78-79, T. 4: 12; 15: 1-3). U Frögu u grobu 2 tumula 50 pronađene su male perle od žutoga stakla (Tomedi 2002: 204, T. 17A: 6), dok su u grobu 1 tumula 168 također bile male žute perle kao i one od zelenkastoplavoga stakla (Tomedi 2002: 204, T. 79: 11).

Grob 37 može se, prema završetku igle te posudi s niskim vratom, datirati u prijelaz IIIb/IV horizont prema C. Metzner Nebelsick (2002: 174-175, sl. 75-76). Posuda s niskim vratom iz groba 37 u Batini, a prema usporedbama u jugoistočnoalpskome krugu, predstavlja stariji oblik od posude u odnosu na onu iz groba 141 u Doroslovu u kojem je pronađena i fibula s nožicom u obliku beotskoga štita tipa $2 b$ prema D. Heilmann koja se datira u drugu polovicu 7. i početak 6. st. pr. Kr. (2016: 15-16, sl. 5).

\section{GROB 38}

Grob 38 (SJ 146/147), s tamnosmeđom zapunom (10YR 4/6), nalazi se u sondi 2 (sl. 5-6). Pravokutna grobna raka zaobljenih uglova dimenzija je 1,98 x 1,90 m, relativne dubine $0,55 \mathrm{~m}$ te okomitih stijenki. $U$ sjeverozapadnome uglu grobne rake nalaze se spaljene kosti odrasloga muškarca (U 161) s paljevinom koje su bile u nekome organskom recipijentu cilindričnoga oblika promjera 0,40 m (sl. 6). Među spaljenim kostima pronađeni su ulomci spaljene brončane igle savijene glavice i okrugloga presjeka (PN 297) (T. 4: 1). $S$ istočne strane spaljenih kostiju nalaze se životinjske kosti zeca i krave (U 162) (sl. 6). Južno od spaljenih kostiju, prema sredini groba, položeni su zdjela zaobljenoga tijela (PN 296) (T. 4: 2) te kantharos (PN 295) (T. 4: 3). Zdjela ima uvučeni i ple, grave 42 also included a light green bead (Trajković 2008: 66, 218/16), while grave 44 contained a dark grey bead (Trajković 2008: 69, 221/18). Grave 84, from an earlier date, included a small blue bead (Trajković 2008: 98, 246/4), while grave 128 , dated to the $8^{\text {th }}$ century $B C$, contained two yellow and one dark glass bead (Trajković 2008: 137, 286/14).

Tumulus 102 at the Pécs - Jakabhegy cemetery contained small turquoise and blue glass beads (MetznerNebelsick 2002: 701, PI. 121: 20). On the other hand, glass beads are exceptionally numerous at the sites around Sopron (Patek 1982b: 162-166, 173, 175), where the most frequent ones are small monochromatic beads and blue beads with yellow eye motifs which are most frequent in the area of the eastern Hallstatt culture (Patek 1982b: 174), which are also known from Batina. The graves under the tumuli at the Sopron - Várhely (Burgstall) cemetery included a large number of small monochrome beads that were parts of necklaces (e.g. tumulus 177), of the kind that was also found in a pit house in the settlement, while it is presumed that some of the finds probably originated from destroyed graves (Patek 1982b: 168, 174, Pls. III-IV; VI: 1). Tumulus 59 contained a bead of light transparent glass and a cylindrical yellow bead, along with those decorated with eye or wave patterns. The beads show traces of cremation with the dead body (Patek 1982b: 173, PI. IX; Eibner-Persy 1980: 51, 164165, PI. 56: 5-6). Tumulus 148 contained beads decorated with eye or wave patterns and small monochrome yellow and blue beads (Patek 1982b: 173, PI. VIII; Eibner-Persy 1980: 51, 185, PI. 77: 4, 6-7). The Masser - Kreuzbauer cemetery also included small beads of opaque yellow glass, which were found in graves $1,12,13$. They were probably worn as parts of necklaces, but they could have been sown into clothes (Bernhard, Weihs 2003: 78-79, PI. 4: 12; 15: 1-3). In Frög, grave 2 of tumulus 50 included small beads of yellow glass (Tomedi 2002: 204, PI. 17A: 6), while grave 1 of tumulus 168 also included small yellow beads and greenish-blue glass beads (Tomedi 2002: 204, PI. 79: 11).

On the basis of the pin tip and the vessel with low neck, grave 37 can be dated to the transition horizon IIIb/IV according to C. Metzner Nebelsick (2002: 174-175, Figs. 75-76). Pursuant to the parallels in the south-eastern Alpine area, the vessel with low neck from grave 37 in Batina represents an older form than the vessel from grave 141 in Doroslovo, which included a double-looped fibula with catch-plates in the form of a Boeotian shield of type $2 b$ according to $D$. Heilmann, dated to the second half of the $7^{\text {th }}$ and the beginning of the $6^{\text {th }}$ century BC (2016: 15-16, Fig. 5).

\section{GRAVE 38}

Grob 38 (SU 146/147), with a dark brown fill (10YR 4/6), is located in Trench 2 (Figs. 5-6). The rectangular grave pit with rounded corners measures $1.98 \times 1.90 \mathrm{~m}$, with a relative depth of $0.55 \mathrm{~m}$ and vertical sides. The north-west corner of the grave pit contained the cremated bones of an adult man (S 161) with burnt remains that used to be stored in a cylindrical organic recipient measuring $0.40 \mathrm{~m}$ in diameter (Fig. 6). Among the cremated bones there were fragments of a burnt bronze pin with bent head and spherical crosssection (SF 297) (PI. 4: 1). To the east of the cremated bones there were animal bones of rabbit and cow (S 162) (Fig. 6). To 


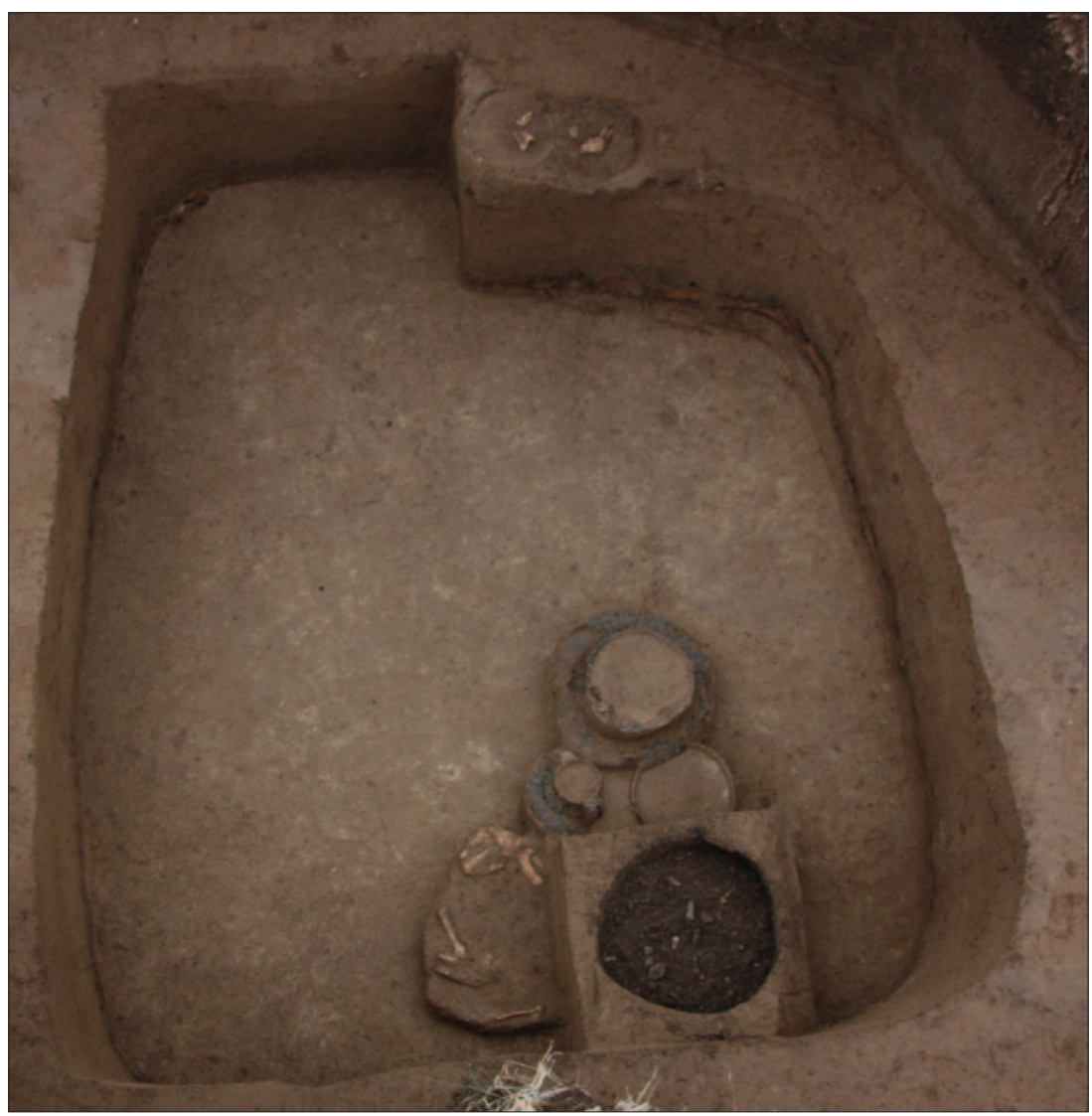

Sl. 5 Grob 38 (snimio: V. Mesarić)

Fig. 5 Grave 38 (photo: V. Mesarić)

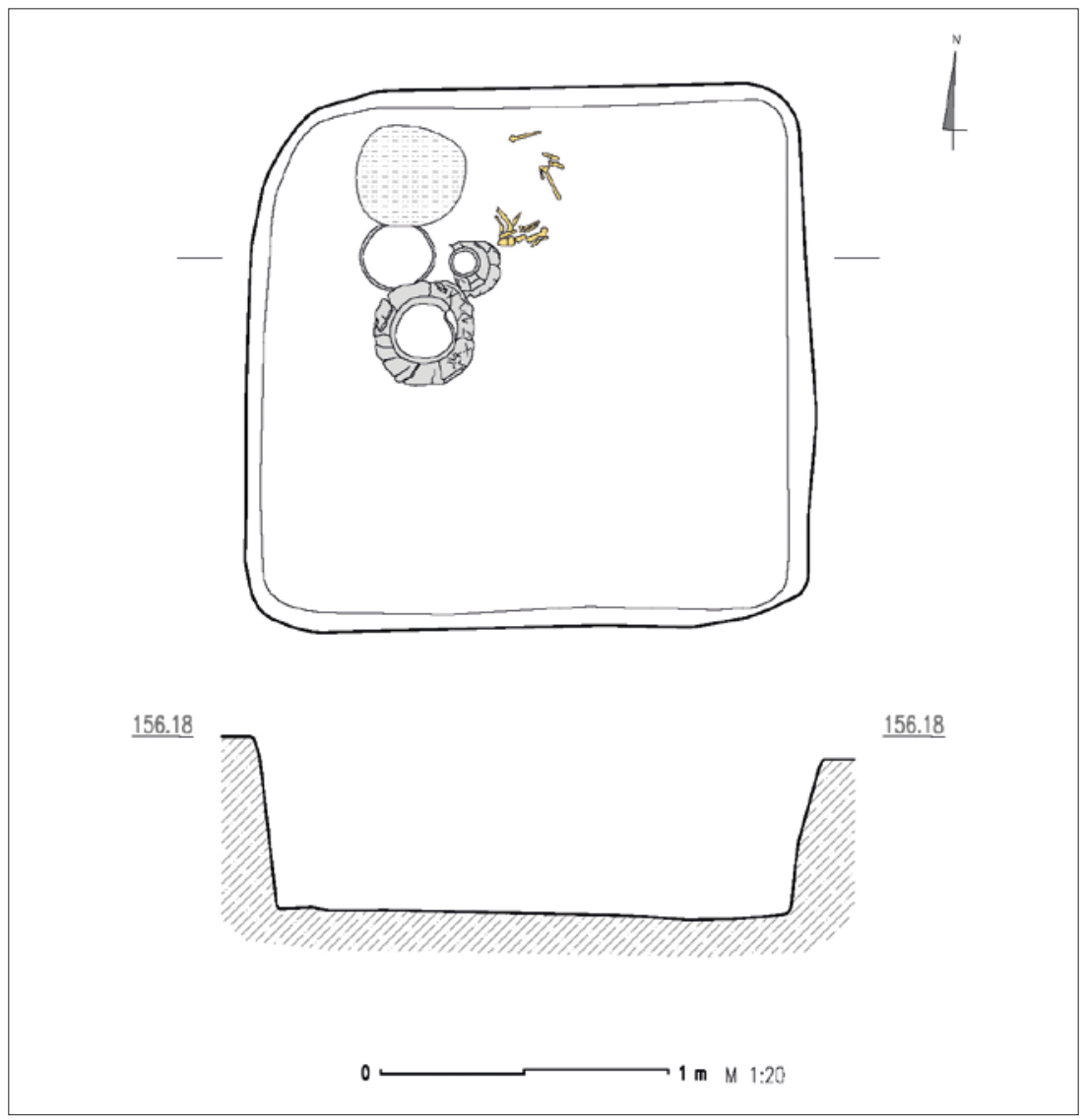

Sl. 6 Grob 38 (crtež: D. Radman; priprema: Arheoplan d.o.o.)

Fig. 6 Grave 38 (drawing: D. Radman; preparation: Arheoplan Ltd.) 
vodoravno kanelirani rub te bradavičasta izbočenja. U zdjeli su pronađeni kralješci ribe (U 201). Kantharos ima bikonično tijelo te je na ramenu ukrašen sa skupinama okomitih kanelura. Trakaste ručke blago prelaze preko ruba posude. Do zdjele i kantharosa, prema središnjem dijelu grobne rake, položen je lonac (PN 294) bikoničnoga tijela koji je na ramenu ukrašen s okomitim rebrima (T. 4: 4). Na prijelazu ljevkastoga vrata u stožasto rame nalazi se plastično rebro. U zapuni grobne rake pronađeni su ulomci keramike.

\section{Lonac}

Usporedbe za lonac iz groba 38 (T. 4: 4) poznate su s groblja u Dalju. Tako je u grobu 3/1909 iz vinograda Panišić pronađen lonac sličnoga oblika s ljevkastim vratom koji je na donjem dijelu ramena ukrašen sa skupinama okomito postavljenih žljebova smještenih ispod bradavičastih izbočenja. Grob je datiran u keramički horizont Illb (Hoffiller 1938: 3, T. 4: 6; Metzner-Nebelsick 2002: 667, T. 64: 11). Dva slična lonca pronađena su i u bogato opremljenome grobu 1 u Sotinu koji je s nalazom brončane fibule s čvorovima na luku tipa 6a datiran u horizont IIlb (Ložnjak Dizdar 2010: 45-46). Na groblju u Doroslovu sličan je lonac pronađen u grobu 42 koji je pripisan horizontu IV. Lonac je na više mjesta na ramenu ukrašen s po jednim okomitim rebrom, dok se na vrhu stožastoga vrata nalaze tri vodoravne kanelure (Trajković 2008: 65, 217/4). U ženskome grobu 110 otkriven je lonac s ljevkasto raširenim rubom koji je na ramenu također ukrašen s po jednim okomitim rebrom. Šire stožasto rame prelazi u kratki vrat na kojem su tri vodoravne kanelure (Trajković 2008: 116, 265/2). Loncu iz groba 38 oblikom i ukrašavanjem odgovara lonac iz groba 9/1963 (sl. 8: 1). Na ramenu su okomita rebra, dok su na vrhu ramena četiri vodoravne kanelure (Trajković 2008: 329, 329/2). Opisani su lonci iz Doroslova datirani u početak starijega željeznog doba (Vasić 2008: 340, 349), odnosno razvoj opisanoga keramičkog oblika može se slijediti od horizonta IIlb, pri čemu su lonci s po jednim vodoravnim rebrom oblik horizonta IV (Metzner-Nebelsick 1996: 301, sl. 11; 2002: 103, 106, 174-175, sl. 75: 2-3; 76: 1).

\section{Zdjela}

Zdjela zaobljenoga tijela ima uvučeni i vodoravno kanelirani rub te bradavičasta izbočenja (T. 4: 2). Radi se o obliku koji se pojavljuje od keramičkoga horizonta Illa, a posebno u horizontima IIIb-IV (Metzner-Nebesick 2002: 136). Slična je zdjela sa širokim vodoravnim kanelurama te četiri jezičaste drške okrenute prema dolje pronađena u Dalju (Metzner-Nebelsick 2002: 657, T. 50: 1). U bogato opremljenome ženskom grobu 6 u Doroslovu pronađena je slična zdjela zaobljenoga tijela i uvučenoga ruba s vodravnim kanelurama te $s$ jednom jezičastom drškom okrenutom prema dolje (Trajković 2008: 30, 184/17). I u ženskom grobu 129 nalazila se zdjela zaobljenoga tijela s vodoravnim kanelurama na uvučenome rubu, s četiri nasuprot postavljena bradavičasta izbočenja (Trajković 2008: 139, 287/6). Inače, na groblju u Doroslovu zdjele zaobljenoga tijela i uvučenog ruba, koji je često ukrašen s vodoravno postavljenim širim kanelurama, vrlo su čest oblik te nerijetko imaju funkciju poklopca urne (Vasić 2008: 341). the south of the cremated bones, towards the centre of the grave, there was a bowl with spherical body (SF 296) (PI. 4: 2) and a kantharos (SF 295) (PI. 4: 3). The bowl has an inverted and horizontally fluted rim and protrusions. The bowl contained fish vertebrae (S 201). The kantharos has a biconical body and is decorated with groups of vertical fluting on the shoulder. The strap handles rise slightly above the vessel rim. Next to the bowl and the kantharos, towards the centre of the grave pit, there is a pot (SF 294) with a biconical body decorated with vertical ribs on the shoulder (PI. 4: 4). The junction of the funnel-shaped neck and the conical shoulder has a relief rib. Pottery sherds were found in the fill of the grave pit.

\section{Pot}

The Dalj cemetery has parallels for the pot from grave 38 (PI. 4: 4). Grave 3/1909 from the Panišić vineyard contained a similarly shaped pot with a funnel-shaped neck decorated with groups of vertical grooves located under protrusions on the lower part of the shoulder. The grave was dated to ceramic horizon IIIb (Hoffiller 1938: 3, PI. 4: 6; MetznerNebelsick 2002: 667, PI. 64: 11). Two similar pots were found in the richly furnished grave 1 in Sotin, which was dated by the found bronze fibula with looped bow of type 6a to horizon IIlb (Ložnjak Dizdar 2010: 45-46). The Doroslovo cemetery had a similar pot in grave 42, associated with horizon IV. The pot is decorated with a single vertical rib in several places on the shoulder, while the top of the conical neck has three horizontal flutes (Trajković 2008: 65, 217/4). Woman's grave 110 contained a pot with a funnel-shaped widening rim, which was also decorated with a single vertical rib on the shoulder. The wide conical shoulder merges into the short neck with three horizontal flutes (Trajković 2008: 116, 265/2). The form and decoration of the pot from grave 38 have a parallel in the pot from grave 9/1963 (Fig. 8: 1). There are vertical ribs on the shoulder and four horizontal flutes at the top of the shoulder (Trajković 2008: 329, 329/2). These pots from Doroslovo were dated to the beginning of the Early Iron Age (Vasić 2008: 340, 349), i.e. the development of this ceramic form can be followed starting from horizon IIlb, with the pots with a single horizontal rib as a form of horizon IV (Metzner-Nebelsick 1996: 301, Fig. 11; 2002: 103, 106, 174-175, Fig. 75: 2-3; 76: 1).

\section{Bowl}

The bowl with a spherical body has an inverted and horizontally fluted rim and protrusions (PI. 4: 2). This form appears in ceramic horizon IIla and particularly in horizons Illb-IV (Metzner-Nebesick 2002: 136). A similar bowl with wide horizontal fluting and four downturned tanged handles was found in Dalj (Metzner-Nebelsick 2002: 657, PI. 50: 1). The richly furnished woman's grave 6 in Doroslovo contained a similar bowl with a spherical body and inverted rim with horizontal fluting and a single downturned tanged handle (Trajković 2008: 30, 184/17). Woman's grave 129 also contained a bowl with a spherical body with horizontal fluting on the inverted rim and four opposing protrusions (Trajković 2008: 139, 287/6). In general, bowls with a spheri- 


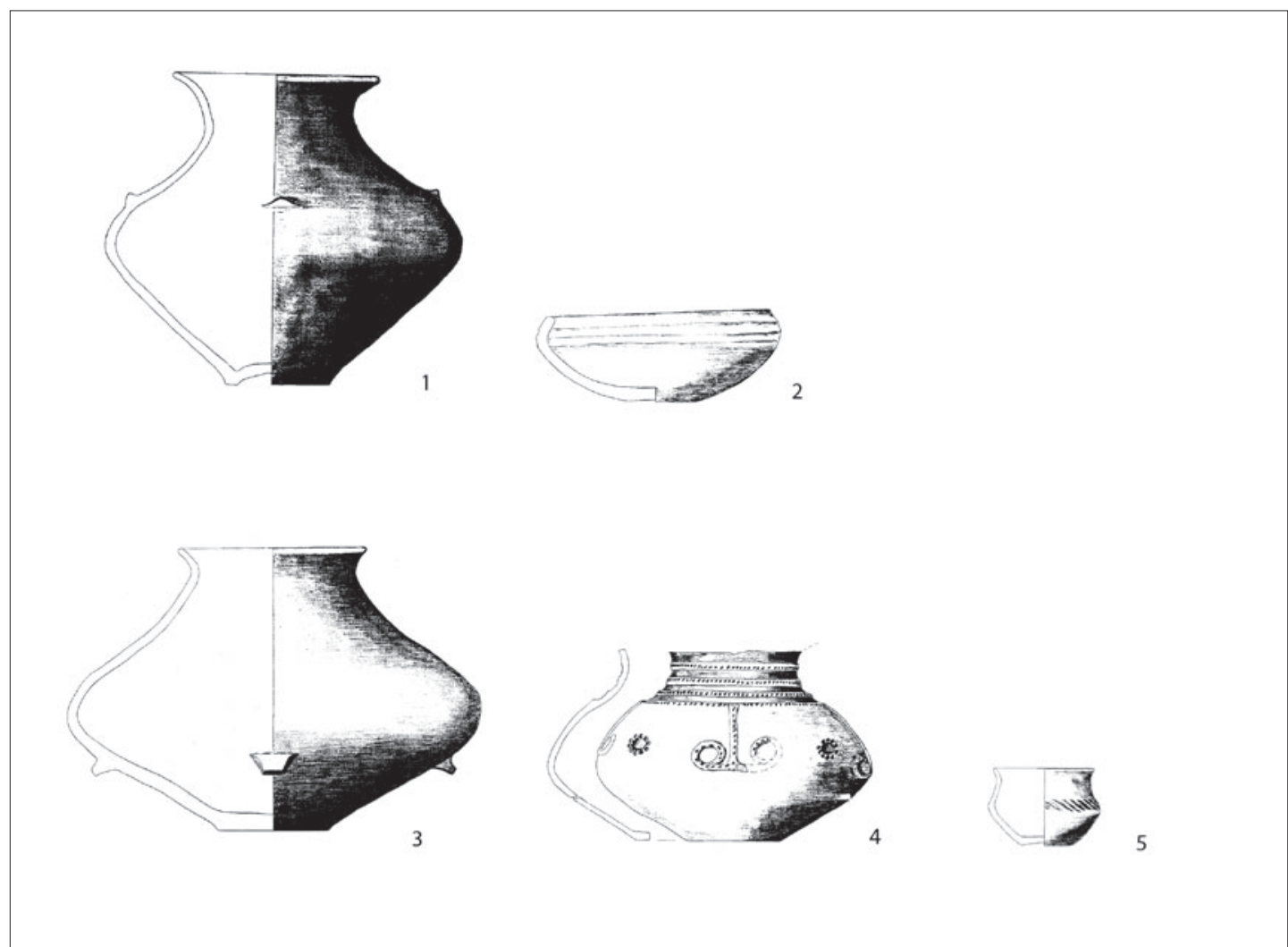

SI. 7 Batina: 1-2 položaj Darašić, grob 1; 3-5 vikendica Matej 1972, grob (prema Metzner-Nebelsick 2002: T. 47: 2-3; 46: 3-5)

Fig. 7 Batina: 1-2 Darašić site, grave 1; 3-5 Matej summer house 1972, grave (according to Metzner-Nebelsick 2002: PI. 47: 2-3; 46: 3-5)

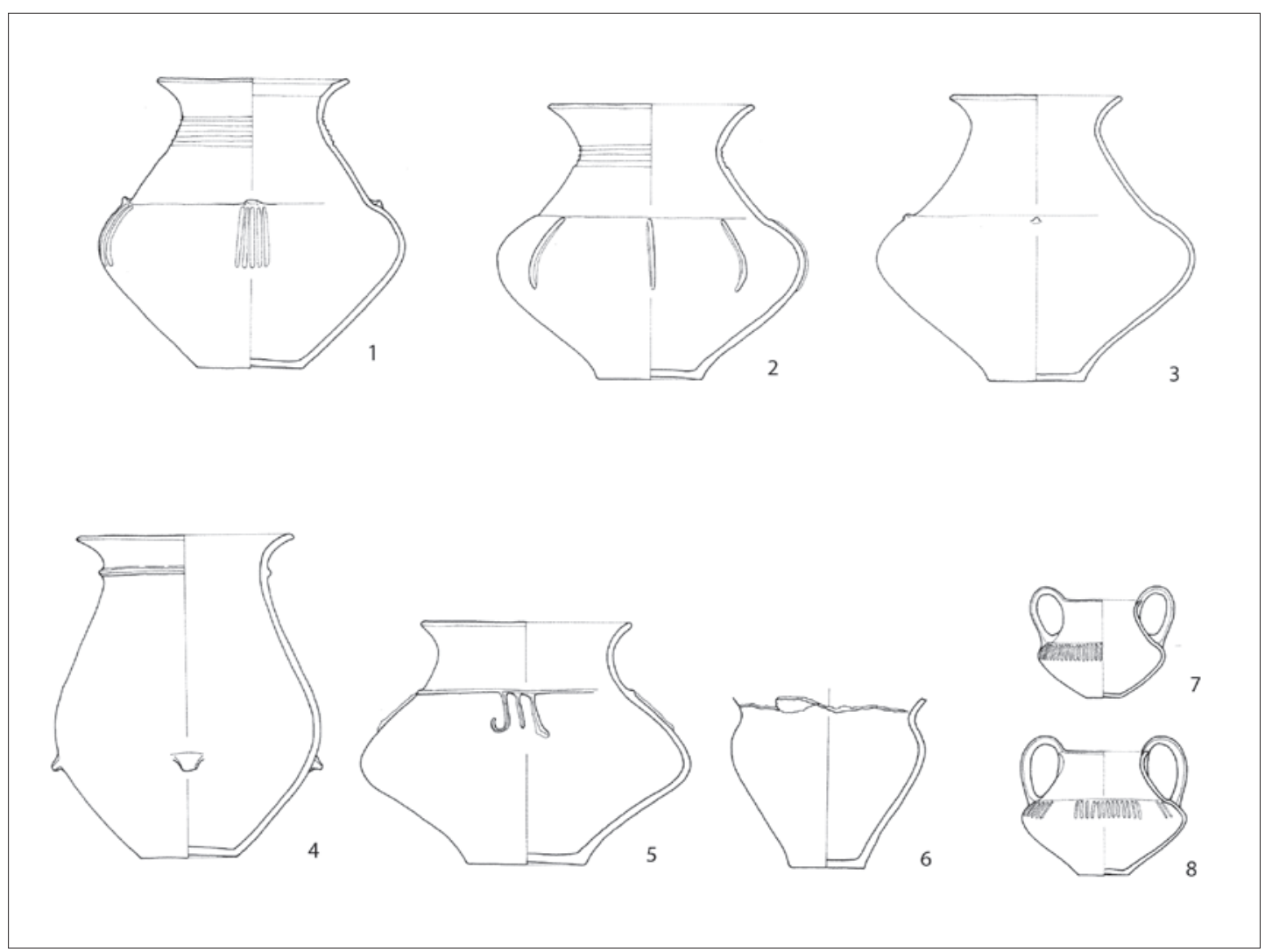

Sl. 8 Doroslovo: grobovi 9 (1-3) i 15 (4-8) iz 1963. godine (prema Trajković 2008: 329-330/1-3; 331-332/1-5) Fig. 8 Doroslovo: graves 9 (1-3) and 15 (4-8) from 1963 (according to Trajković 2008: 329-330/1-3; 331-332/1-5) 


\section{Kantharos}

Kantharos iz groba 38 (T. 4: 3) oblikom je sličan onomu iz groba 37. Razlika se prepoznaje u tome što je kantharos iz groba 38 na ramenu ukrašen samo sa skupinama okomitih kanelura između kojih su neukrašeni dijelovi, odnosno nedostaju kružna udubljenja. Kantharosi ovoga oblika i načina ukrašavanja karakteristični su za keramičke horizonte IIIb i IV (Metzner-Nebelsick 2002: 125, 174-175, sl. 75: 9; 76: 5) te su od ranije poznati iz Batine (Metzner-Nebelsick 2002: 613-614, T. 22: 5; 616, T. 26: 2; 620, T. 30: 12; 639-640, T. 35 : 1). Isto tako, s groblja u Dalju, iz groba $23 / 1911$ u vinogradu Panišić, potječe kantharos ukrašen na isti način sa skupinama okomitih kanelura, pri čemu je grob datiran u horizont IIIb (Hoffiller 1938: T. 13: 11; Metzner-Nebelsick 2002: 667, T. 68: 1).

Na groblju u Doroslovu također su pronađeni kantharosi ukrašeni sa skupinama okomitih kanelura između kojih se nalaze neukrašeni dijelovi, pri čemu su manje razlike primjetne u obrisu tijela kantharosa: grob 31 (Trajković 2008: 52, 210/5); grob 46 (Trajković 2008: 70, 222/3); grob 111 (Trajković 2008: 118, 266/5); grob 113 (Trajković 2008: 120, 268/4); grob 115 (Trajković 2008: 123, 271/3); grob 130 (Trajković 2008: 141, 290/11); grob 134 (Trajković 2008: 146, 294/9); grob 15/1963 (Trajković 2008: 332, 332/3). Zanimljivo je kako se ovaj način ukrašavanja, osim u Batini, pojavljuje u Dalju, Vukovaru i Vinkovcima na kantharosima i plitkim zdjelama (Metzner-Nebelsick 2002: sl. 67; 70: 4 I/3).

\section{Brončana igla spiralo uvijene glavice}

Među spaljenim kostima koje su se, zajedno s paljevinom, nalazile u nekom organskom recipijentu, pronađeni su ulomci spaljene brončane igle savijene glavice i okrugloga presjeka (T. 4: 1).

Brončana igla ovoga oblika i okrugloga presjeka, koja je sačuvana u više ulomaka, pronađena je u grobu 152 na groblju Doroslovo. Pored igle, u grobu su pronađeni i brojni željezni predmeti (Trajković 2008: 173, 323/20; Vasić 2008: 343). Brončana igla sa savijenom glavicom, za koju se pretpostavlja kako predstavlja dio muške nošnje, pronađena je na groblju na Pošteli izvan grobne cjeline. Igle savijene glavice pojavljuju se u grobovima $\mathrm{Ha} C$, možda i ranije (Teržan 1990: 70, T. 63: 11). Iz Fröga, iz tumula 11 sa sjekirom sa zaliscima, potječe igla savijene glavice, dok su još dvije igle pronađene izvan konteksta. Ove se igle široko datiraju od starije kulture polja sa žarama do početka starijega željeznog doba (Tomedi 2002: 167, T. 5A: 2; 92F: 6-7; 102: 12-13). Ulomak savijene glavice igle poznat je iz tumula 103 na groblju Sopron - Várhegy, pri čemu su igle s tordiranim tijelom datirane u Ha C1 (Eibner-Persy 1980: 50, 81, 177, T. 71: 4). Ovaj tip igala široko je rasprostranjen i isto tako datiran. Pojavljuju se u velikome broju u Srijemu i na području zapadne Mađarske još od kasnoga brončanog doba (Vasić 2003: 21-23, T. 52; Říhovský 1983: 32, T. 11-12).

S obzirom na pronađene nalaze, grob 38 u Batini datira se u Illb horizont, pri čemu se najuže može datirati tip lonca sa stožastim vratom i plastičnim rebrima na trbuhu. cal body and inverted rim, which is often decorated with wide horizontal fluting, are a very frequent form at the Doroslovo cemetery, often serving as urn lids (Vasić 2008: 341).

\section{Kantharos}

The kantharos from grave 38 (PI. 4:3) has a similar form as the one from grave 37. The difference is that the shoulder of the kantharos from grave 38 is decorated only with groups of vertical flutes alternating with undecorated parts, meaning that there are no circular depressions. The kantharoi of this form and decoration method are characteristic for ceramic horizons IIIb and IV (Metzner-Nebelsick 2002: 125, 174-175, Fig. 75: 9; 76: 5) and are already known from Batina (Metzner-Nebelsick 2002: 613-614, PI. 22: 5; 616, PI. 26: 2; 620, PI. 30: 12; 639-640, PI. 35: 1). Moreover, grave 23/1911 from the Panišić vineyard at the Dalj cemetery contained a kantharos decorated in the same way with groups of vertical flutes, and the grave was dated to horizon IIIb (Hoffiller 1938: PI. 13: 11; Metzner-Nebelsick 2002: 667, PI. 68: 1).

The Doroslovo cemetery also included kantharoi decorated with groups of vertical flutes alternating with undecorated parts, with small differences in the body shape of the kantharos: grave 31 (Trajković 2008: 52, 210/5); grave 46 (Trajković 2008: 70, 222/3); grave 111 (Trajković 2008: 118, 266/5); grave 113 (Trajković 2008: 120, 268/4); grave 115 (Trajković 2008: 123, 271/3); grave 130 (Trajković 2008: 141, 290/11); grave 134 (Trajković 2008: 146, 294/9); grave 15/1963 (Trajković 2008: 332, 332/3). Interestingly, this decoration method appears not only in Batina, but also on kantharoi and shallow bowls in Dalj, Vukovar, and Vinkovci (MetznerNebelsick 2002: Fig. 67; 70: 4 I/3).

\section{Bronze pin with a spirally bent head}

Among the cremated bones that were stored in an organic recipient together with burnt remains, there were fragments of a burnt bronze pin with a bent head and circular cross-section (PI. 4: 1).

A bronze pin of this form and circular cross-section, preserved in several fragments, was found in grave 152 at the Doroslovo cemetery. Along with the pin, the grave contained numerous iron objects (Trajković 2008: 173, 323/20; Vasić 2008: 343). A bronze pin with a bent head, which is presumed to be an item of man's costume, was found at the Poštela cemetery outside the funerary complex. Pins with a bent head appear in graves from $\mathrm{Ha} \mathrm{C}$, maybe even earlier (Teržan 1990: 70, PI. 63: 11). In Frög, tumulus 11 with a winged axe included a pin with a bent head, while another two pins were found outside the context. These pins are broadly dated from the older Urnfield culture to the beginning of the Early Iron Age (Tomedi 2002: 167, PI. 5A: 2; 92F: 6-7; 102: 12-13). A fragment of the bent head of a pin is known from tumulus 103 at the Sopron - Várhegy cemetery, with pins with a twisted body dated to Ha C1 (Eibner-Persy 1980: 50, $81,177, \mathrm{PI} .71: 4)$. This type of pins is widely distributed and as widely dated. They appear in large numbers in Syrmia and the area of western Hungary starting in the Late Bronze Age (Vasić 2003: 21-23, PI. 52; Říhovský 1983: 32, Pls. 11-12).

Considering the finds, grave 38 in Batina is dated to ho- 


\section{ZAKLJUČAK}

Predstavljena tri groba iz Batine ukazuju na izuzetnu važnost rezultata sustavnih istraživanja koja su započela 2010. godine na položaju Sredno, s kojega vjerojatno potječu i brojni nalazi koji su danas pohranjeni u brojnim europskim muzejskim ustanovama. Za spomenute nalaze nisu poznati konteksti njihova otkrića, što potom utječe na mogućnost njihova preciznijeg datiranja, posebno keramičkih posuda koje su najbrojniji nalazi na grobljima na prostoru daljske grupe i stoga su ključni za definiranje lokalne kronologije (Vinski-Gasparini 1983: 606; Metzner-Nebelsick 1996; 2002: 127-179).

Groblje na Srednom, s naseljem na Gracu, pripada daljskoj grupi čiji je razvoj obilježio mlađu fazu kasnoga brončanog doba te početak starijega željeznog doba na prostorima Baranje i susjedne jugoistočne Transdanubije, zatim istočne Slavonije i zapadnoga Srijema te jugozapadne Bačke. Pored istraženih groblja u Dalju, Osijeku, Vukovaru, Sotinu, Doroslovu i Pécs - Jakabhegyu, možda upravo Batina predstavlja jedno od vrlo važnih središta daljske grupe o čemu svjedoče brojni slučajni nalazi koji su prikupljeni početkom 20. stoljeća, a poslužili su, pored spomenutih groblja, u kronološkom definiranju razvoja daljske grupe s izdvojenim keramičkim horizontima (Metzner-Nebelsick 2002). Otkriće novih grobnih cjelina u Batini predstavljati će izvrsnu nadopunu u definiranju prepoznatih keramičkih horizonata, odnosno omogućiti će još bolje poznavanje karakterističnih keramičkih servisa za svaku pojedinu fazu razvoja daljske grupe. Pored Batine, svakako je od velike važnosti i objava rezultata dugogodišnjih istraživanja groblja Doroslovo u jugozapadnoj Bačkoj s vrijednim podacima o sadržaju zatvorenih grobnih cjelina (Trajković 2008) čija je analiza pokazala kako se ponekad u okviru istih grobova pojavljuju keramičke posude koje su u podjeli C. Metzner-Nebelsick izdvojene u različite keramičke horizonte (Vasić 2008: 347). Naravno, neki se oblici mogu pojavljivati i tijekom više keramičkih horizonata, posebno jednostavniji oblici kao što su različite zdjele zaobljenoga tijela i uvučenoga ruba, zatim šalice, pa čak i kantharosi s metopno organiziranim ukrasima. Inače, pokopavanje na groblju u Doroslovu počinje na prijelazu starije u mlađu fazu kulture polja sa žarama i traje do kraja 7. st. pr. Kr., na što ukazuju i rezultati dosad provedenih istraživanja u Batini. Razlika između ova dva prostorno bliska te istovremena groblja prepoznaje se u većem broju metalnih predmeta u grobovima u Batini koji se mogu datirati na početak starijega željeznoga doba, pri čemu neki od davno prikupljenih nalaza ukazuju na postojanje istaknutih pojedinaca koji su bili pokopani s prestižnim dobrima, od kojih su neka pristigla iz udaljenih područja, a što su potvrdila i posljednja iskopavanja na Srednom.

Prikazani grobovi sa Srednoga, na osnovi pronađenih nalaza, pripadaju različitim keramičkim horizontima prema podjeli C. Metzner-Nebelsick. Grob 36, na osnovi oblika lonca u funkciji urne, može se datirati u keramički horizont Illa, odnosno u 8. st. pr. Kr. te pripada početnoj fazi razvoja starijega željeznog doba, što potvrđuju i dokumentirane rizon IIIb, with the narrowest dating for the pot type with a conical neck and relief ribs on the belly.

\section{CONCLUSION}

The presented three graves from Batina point to the exceptional importance of the results of the systematic excavations started in 2010 at the Sredno site, which is probably the origin of the numerous finds which are now stored in numerous European museums. These are finds with unknown discovery contexts, which affect the possibility to date them more precisely, especially for the ceramic vessels that are the most numerous finds at the cemeteries in the area of the Dalj group and therefore crucial for defining the local chronology (Vinski-Gasparini 1983: 606; MetznerNebelsick 1996; 2002: 127-179).

The cemetery at Sredno, with the settlement on Gradac, belongs to the Dalj Group, whose development marked the younger phase of the Late Bronze Age and the beginning of the Early Iron Age on the territory of Baranya and neighbouring southeastern Transdanubia, as well as eastern Slavonia, western Syrmia, and south-western Bačka. Aside from the explored cemeteries in Dalj, Osijek, Vukovar, Sotin, Doroslovo, and Pécs - Jakabhegy, Batina may be one of the crucial centres of the Dalj Group, as testified by the numerous chance finds collected at the beginning of the $20^{\text {th }}$ century, which helped, along with the mentioned cemeteries, to chronologically define the development of the Dalj Group with distinct pottery horizons (Metzner-Nebelsick 2002). The discovery of the new funerary complexes in Batina will be an excellent complement to defining the recognised pottery horizons and to an even better understanding of the characteristic pottery sets for each development phase of the Dalj Group. Aside from Batina, another very important event is the publication of the results of several years of excavations in the Doroslovo cemetery in southwestern Bačka, with valuable data about the contents of the closed funerary complexes (Trajković 2008), where analysis showed that the same graves could contain ceramic vessels which were separated into different ceramic horizons according to the classification of C. Metzner-Nebelsick (Vasić 2008: 347). Of course, some forms can appear during several ceramic horizons, especially simpler forms such as different bowls with a spherical body and inverted rim, cups, and even kantharoi with metope-organised decorations. The burials at the Doroslovo cemetery started during the transition from the older to the younger phase of the Urnfield culture and lasted until the end of the $7^{\text {th }}$ century BC, as indicated by the results of past excavations in Batina. The difference between these geographically close and contemporary cemeteries can be seen in the large number of metal objects in the graves in Batina that can be dated to the beginning of the Early Iron Age, with some of the finds collected long ago pointing to the existence of prominent individuals who were buried with prestigious goods, some of them brought from remote areas, as confirmed by recent excavations at Sredno.

On the basis of the finds, the presented graves from Sredno belong to different ceramic horizons according to 


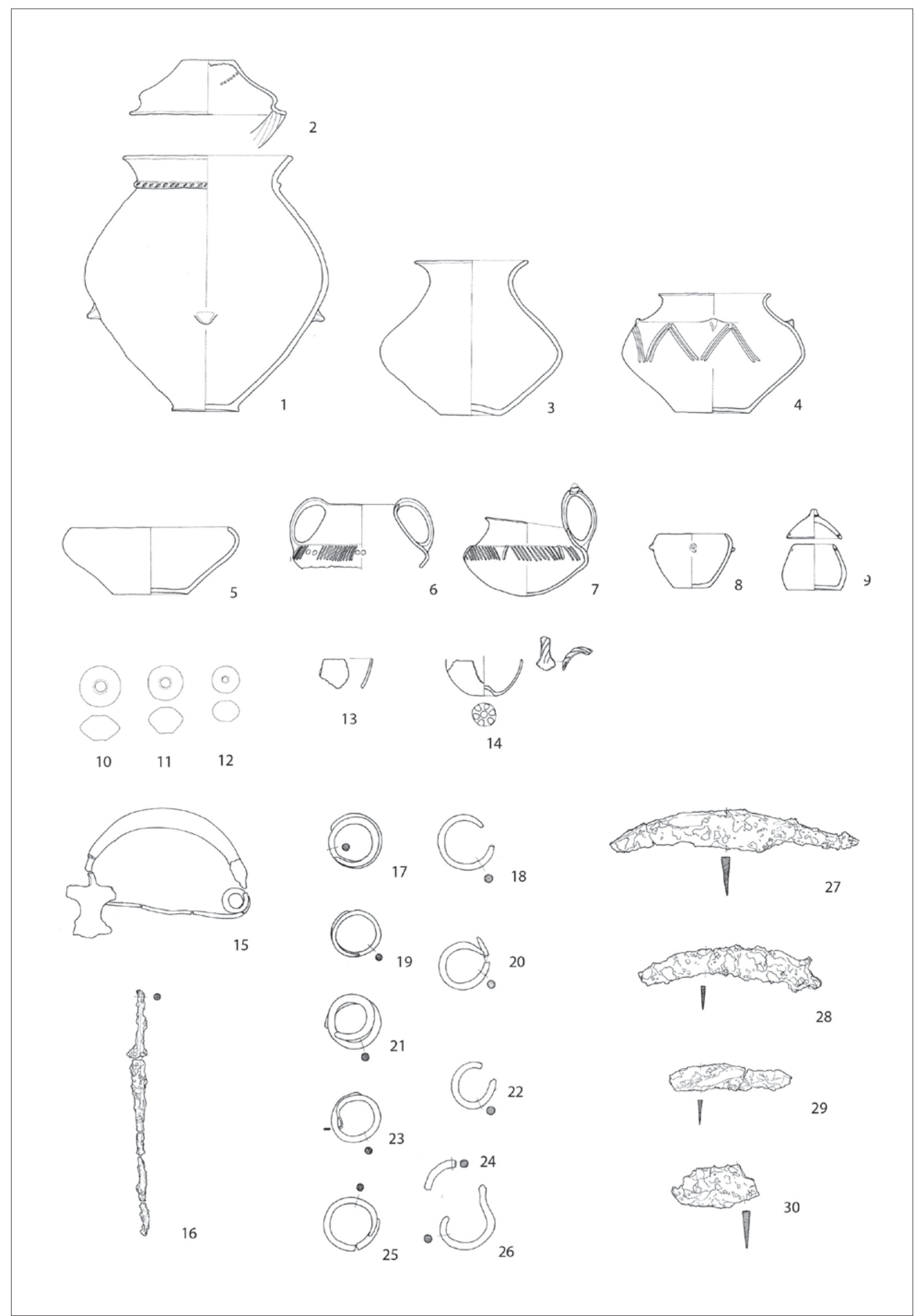

SI. 9 Doroslovo, grob 141 (prema Trajković 2008: 306-308/1-31)

Fig. 9 Doroslovo, grave 141 (according to Trajković 2008: 306-308/1-31) 
usporedbe. Zanimljivo je kako u grobu nije bilo drugih keramičkih posuda. U grobu su vjerojatno"1 pokopani istaknuta žena i dijete o čemu svjedoče nalazi brončanih spiralnih vitica za kosu koje su bile spaljene s pokojnicom te brončane perle koje su vjerojatno bile nošene kao ogrlica, zajedno $s$ jednom staklenom perlom koja je ukrašena s motivima oka. Posebno je zanimljivo što su brončane perle pronađene u loncu, zajedno sa spaljenim kostima, dok je samo jedna perla bila u ostacima paljevine koja je bila položena na dno grobne rake južno od urne. Radi se o ostacima s lomače koji su bili prikupljeni sa spaljenim kostima odrasle osobe, no nisu bili položeni u lonac, već su stavljeni na dno grobne rake. Sličan je grobni ritual zabilježen i u grobu 37 kao i u većem broju istraženih grobova na Srednom. Prilozi dva keramička pršljena potvrđuju kako se radi o pokopu žene, budući da su oni karakterističan rodni grobni prilog kako na Srednom, tako i na groblju u Doroslovu. Možda je i keramički predmet sa zupcima imao neku funkciju u domaćinstvu koju su obavljale žene, no njegova namjena zasad ostaje nepoznata. Položaj keramičkoga predmeta u grobu blizu lonca gdje su bili spaljeni ostaci djeteta, možda bi ukazivao i na drugačiju funkciju, ali su četiri završetka na keramičkoj alatci izuzetno oštra pa uloga igračke nije uvjerljiva.

Vremenski bi slijedio grob 38 s posudama koje ukazuju na pripadnost keramičkome horizontu Illb, odnosno kraju 8. i prvoj polovici 7. st. pr. Kr. Potvrđivao bi to i nalaz brončane igle sa savijenom glavicom koja ukazuje na pokop muškarca. Najmlađi je grob 37 sa zanimljivim keramičkim prilozima koji bi ukazivali na datiranje groba u keramički horizont lllb/ IV, odnosno oko sredine 7. st. pr. Kr. U grobu je pronađen $\mathrm{i}$ završetak brončane višeglave igle koji bi potvrđivao slično vremensko određenje, iako postoje mišljenja kako se opisani završeci igala mogu datirati i ranije. Zanimljivo je kako su grobovima 37 i 38 pronađeni kantharosi sličnoga oblika, ukrašeni na ponešto drugačiji način, no izrađeni prema istome idejnom konceptu.

Kantharosi se pojavljuju kao recipijenti za piće i već je istaknuto kako su česti nalaz u grobovima u Batini, Dalju, Sotinu i Doroslovu. Njihova pojava u servisima u kojima je bila položena hrana i piće u grobovima svjedoči kako je pogrebna gozba bila važan dio ispraćaja mrtvih (Nebelsick 1994; 2016). Groblja u Podunavlju su najistočnija mjesta gdje se može pratiti koncept pogrebne gozbe vidljive $u$ prilozima keramičkih posuda i ostataka životinjskih kostiju u grobovima. Ovakav koncept je uobičajen za istočni halštatski krug, a korijeni takvih običaja zabilježeni su već tijekom kulture polja sa žarama na prostoru srednjega Podunavlja (Nebelsick 1994: 357; 1997: 71-72) i južnoga dijela Karpatske kotline. Nalaz šalice u loncu u grobu 37 u Batini svjedoči kako je posuda sadržavala tekućinu za piće, a nalaz koštica grožđa u istome tipu posude u tumulu 1 u Zagersdorfu uka-

11 Antropološkom analizom određeno je kako spaljeni ostaci pripadaju odrasloj osobi, ali prema ostalim prilozima u grobovima pretpostavlja se kako se radi o ženi koja je bila spaljena na lomači zajedno s djetetom čiji su ostaci stavljeni u urnu. Zajedničko spaljivanje pretpostavlja se prema prilozima koji su bili stavljeni u urnu i onima koji su pronađeni u ostacima lomače sa spaljenim kostima odrasle osobe položenima sa strane. the classification of C. Metzner-Nebelsick. Grave 36, on the basis of the form of the pot serving as urn, can be dated to ceramic horizon IIla, i.e. to the $8^{\text {th }}$ century $\mathrm{BC}$, and belongs to the initial phase of the development of the Early Iron Age, as confirmed by documented comparisons. Interestingly, the grave did not contain other ceramic vessels. The grave was probably ${ }^{11}$ the resting place of a prominent woman and child, as testified by the finds of bronze spiral hair ringlets that were cremated with the dead woman and bronze beads that were probably carried as a necklace, together with a glass bead decorated with eye motifs. It is of particular interest that the bronze beads were found inside the pot with the cremated bones, while only one bead was in the burnt remains placed at the bottom of the grave pit south of the urn. They are the remains of the pyre, collected together with the cremated bones of an adult; however, they were not put inside the pot but placed at the bottom of the grave pit. A similar funerary rite was recorded in grave 37 and in many of the explored graves at Sredno. Two ceramic spindle whorls as grave goods confirm that it was the burial of a woman, since they are a characteristic gender grave good both at Sredno and at the Doroslovo cemetery. The ceramic object with prongs could also have had a household use performed by women, but its purpose is still unknown. The position of the ceramic object in the grave, next to the pot with the cremated remains of the child, might indicate a different function, but the four tips of the ceramic tool are very sharp, so the role of a toy does not seem convincing.

Chronologically, grave 38 is next, with vessels which indicate they belong to ceramic horizon IIIb, i.e. the end of the $8^{\text {th }}$ and the first half of the $7^{\text {th }}$ century BC. This seems to be confirmed by the find of the bronze pin with the bent head, indicating the burial of a man. The youngest grave is grave 37 , with interesting ceramic goods that seem to indicate that the grave should be dated to ceramic horizon IIIb/IV, i.e. around the middle of the $7^{\text {th }}$ century BC. The grave also contained the tip of a bronze multi-head pin, which seems to confirm a similar dating, even though there are opinions that these pin tips could be dated to an earlier time. Curiously, graves 37 and 38 contained kantharoi of a similar form, decorated somewhat differently, but made on the basis of the same ideal concept.

Kantharoi appear as recipients for drinks and, as already pointed out, they are a frequent find in the graves in Batina, Dalj, Sotin, and Doroslovo. Their appearance in the sets containing food and drink in the graves shows that the funerary feast was an important part of the last farewell (Nebelsick 1994; 2016). The Danube valley cemeteries are the easternmost places where one can follow the concept of the funerary feast which is visible in the grave goods consisting of ceramic vessels and animal bone remains. This concept is usual for the eastern Hallstatt sphere, and there are recorded roots of these customs already during the Urnfield culture in the area of the middle Danube (Nebelsick 1994: 357;

11 Anthropological analysis has determined that the cremated remains belong to an adult, but other grave goods are the basis for the assumption that it was a woman burned on the pyre together with a child, whose remains were put in the urn. Joint cremation is supposed because of the goods in the urn and those found in the pyre remains together with the burned bones of an adult, which were placed next to it. 


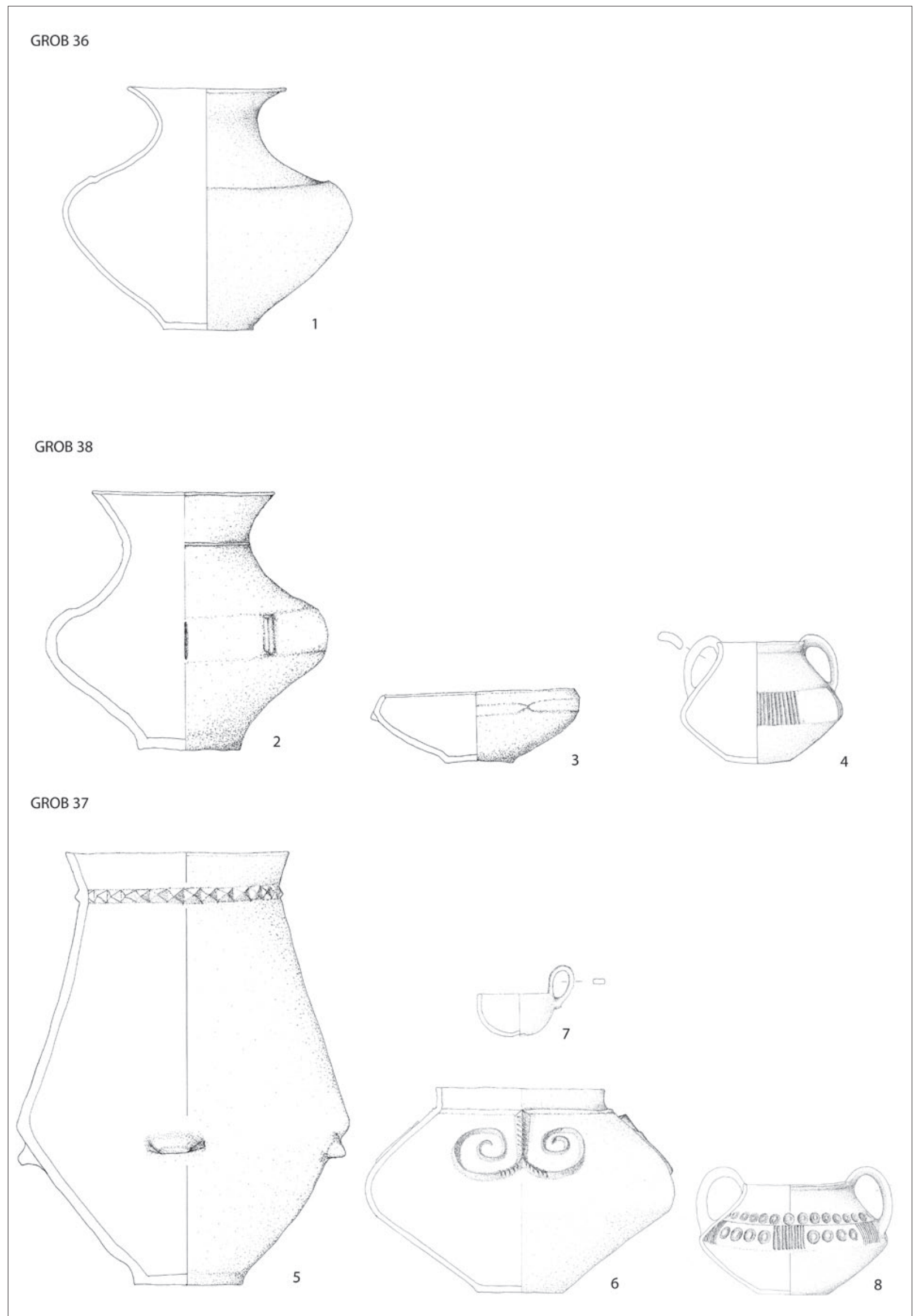

SI. 10 Batina, keramičke posude iz grobova 36,38 i 37

Fig. 10 Batina, ceramic vessels from graves 36,38 and 37 
zuje koje piće se koristilo u pogrebnoj gozbi (Rebay 2002: 42-43, 80, T. 18-20; 21: 1). Pojava šalica i/ili kantharosa u loncima u grobovima svjedoči kako je većina lonaca sadržavala tekućinu za piće.

Rezultati dosadašnjih istraživanja u Batini na Srednom, koja su započela 2010. godine i provode se u kontinuitetu, s otkrićem većega broja grobnih cjelina s raznovrsnim keramičkim servisima, pružaju dobru osnovu za buduće analize izdvojenih keramičkih horizonata (Fig. 10). Uz tipove lonaca koji se pojavljuju kao urne (sl. 10: 1, 5), važnu ulogu u lokalnoj kronologiji imati će lonci korišteni kao recipijenti za tekućinu (sl. 10: 2, 6), pri čemu izuzetan lokalni korektiv među dosad istraženim grobovima predstavljaju i kantharosi (sl. 10: 4, 8). Dosadašnje analize (Vinski-Gasparini 1983; Metzner-Nebelsick 2002; 2017a; Tasić 1994; Šimić 2004; Vasić 2008) ukazale su na složenost proučavanja materijalne ostavštine zajednica na početku starijega željeznog doba u južnome dijelu srednjega Podunavlja, a podaci dobiveni recentnijim istraživanjima otvaraju nove izazove u njihovom potpunijem sagledavanju. Upravo predstavljana tri izdvojena groba ukazuju na svu kompleksnost postojeće kronološke razdiobe daljske grupe te će njezina reevaluacija biti jedan od osnovnih izazova u istraživanju groblja u Batini. Isto tako, pružaju se mogućnosti za proučavanje rodno i dobno karakterističnih keramičkih servisa kao i ispitivanje njihovoga odnosa prema društvenome položaju pokojnika, u čemu veliku važnost imaju i rezultati bioarheoloških istraživanja.
1997: 71-72) and the southern Carpathian Basin. The find of a cup in grave 37 in Batina testifies that the vessel contained a drink, and the find of grape seeds in the same type of vessel in tumulus 1 in Zagersdorf indicates which drink was chosen for the funerary feast (Rebay 2002: 42-43, 80, Pls. 18-20; 21: 1). The appearance of cups and/or kantharoi in pots in the graves shows that most pots contained drinks.

The results of the excavations in Batina at Sredno, which started in 2010 and have been continuous since then, with the discovery of a large number of funerary complexes with various pottery sets, provide a good basis for future analyses of distinct pottery horizons (Fig. 10). Along with pot types serving as urns (Fig. 10: 1, 5), an important role in the local chronology will be played by pots serving as recipients for liquids (Fig. 10: 2, 6), with kantharoi being an exceptional local corrective among the explored graves (Fig. 10: 4, 8). The past analyses (Vinski-Gasparini 1983; MetznerNebelsick 2002; 2017a; Tasić 1994; Šimić 2004; Vasić 2008) have shown the complexity of researching the material heritage of the communities at the beginning of the Early Iron Age in the southern part of the middle Danube, and the data obtained by recent research has opened up new challenges for considering them more fully. The three graves that we singled out and presented show all the complexity of the current chronological classification of the Dalj group; therefore, its re-evaluation will be one of the fundamental challenges when researching the cemetery in Batina. Moreover, there are new possibilities for the research of gender and age specific ceramic sets and the examination of their relation to the social status of the dead, where the results of bioarchaeological research have great importance too.

Prijevod i lektura / Translation and proofreading Marko Maras 


\section{LITERATURA / BIBLIOGRAPHY}

Berg, F. 1962, Das Flachgräber der Hallstattkultur von Maiersch, Veröffentlichungen der Österreichischen Arbeitsgemeinschaft für Ur- und Frühgeschichte IV, Wien.

Bernhard, A., Weihs, A. 2003, Neuerforschte Gräber der frühen Eisenzeit in Kleinklein (Weststeirmark), Universitätforschungen zur Prähistorischen Archäologie, Band 93, Dr. Rudolf Habelt GmbH, Bonn.

Bojčić, Z. 1977, Gradac, Batina - prethistorijsko nalazište, Arheološki Pregled, Vol. 19, 41-43.

Bojčić, Z., Dizdar, M., Hršak, T., Vukmanić, I., Dujmić, D., Leleković, T. 2009, Terenski pregled područja Batine, Annales Instituti Archaeologici, Vol. V, 125-129.

Bojčić, Z., Dizdar, M., Hršak, T., Leleković, T. 2010, Terenski pregeld područja između Batine i Suze, Annales Instituti Archaeologici, Vol. VI, 80-87.

Bojčić, Z., Dizdar, M., Hršak, T., Leleković, T. 2011, Rezultati probnih istraživanja nalazišta Batina-Sredno 2010. godine, Annales Instituti Archaeologici, Vol. VII, 13-19.

Brukner, O. 1959, Halštatska nekropola kod Doroslova, Građa za proučavanje spomenika kulture Vojvodine, Vol. III, 1-13.

Bulat, M. 1962, Arheološki odio: Obilasci arheološkog terena od 1. I. 1961. do 31. XII. 1962. i važnije prinove, Osječki Zbornik, Vol. VIII, 364-368.

Bulat, M. 1964, Rekognosciranje limesa između Batine Skele i lloka, Arheološki Pregled, Vol. 6, 63-64.

Bulat, M. 1970a, Gradac, Batina skela - naselje od srednjobrončanog do željeznog doba i rimski logor, Arheološki Pregled, Vol. 12, 42-43.

Bulat, M. 1970b, Najnovija istraživanja u Batini Skeli, Glasnik Slavonskih Muzeja, Vol. 5, 17-18.

Bulat, M. 1974, Rekognosciranja prethistorijskih lokaliteta u Slavoniji, Arheološki Pregled, Vol. 16, 152-154.

Bulat, M. 1977, Stanje istraživanja antičkih naselja u Slavoniji, Materijali Saveza arheoloških društva Jugoslavije, Vol. 13, 63-91.

Bulat, M. 1981, Rekognosciranja Arheološkog odjela Muzeja Slavonije, Arheološki Pregled, Vol. 22, 181-187.

Bulat, M. 1984, Neki noviji antički nalazi iz Slavonije i Baranje, Izdanja Hrvatskog arheološkog društva, Vol. 9, 117-128.

Childe, V. G. 1929, The Danube in prehistory, At the Clarendon Press, Oxford.

Dobiat, C. 1980, Das hallstattzeitliche Gräberfeld von Klein-Klein und seine Keramik, Schild von Steier, Beiheft 1, Graz.

Dujmić, D. 2011, Dva žarna groba iz Batine, Osječki Zbornik, Vol. XXX, $59-72$.

Egg, M. 1998, Einige Bemerkungen zum hallstattzeitlichen Wagengrab von Somlóvásárhely, Kom. Veszprém in Westungarn, Jahrbuch des Röhmisch-Geramisches Zentralmuseums Mainz, Vol. 43/1 (1996), 327-353.

Eibner-Persy, A. 1980, Hallstattzeitliche Grabhügel von Sopron (Ödenburg), Die Funde der Grabungen 1890-92 in der Prähistorischen Abteilung des Naturhistorischen Museum in Wien und im Burgenländischen Lanesmuseum in Eisenstadt, Wissenschaftliche Arbeiten aus dem Burgenland, Heft 62, Eisenstadt.

Foltiny, S. 1961, Über die Fundstelle und Bedeutung der angeblich aus Kisköszeg stammenden hallstattzeitlichen Bronzen des RömischGermanischen Zentralmuseums in Mainz, Jahrbuch des RöhmischGeramisches Zentralmuseums Mainz, Vol. 8, 175-189.

Gallus, S., Horváth, T. 1939, Un peuple cavalier préscythique en Hongrie. Trouvailles archéologiques du premier âge du fer et leurs relations avec l'eurasie, Dissertationes Panonicae, Ser. II. Fasc. 9, Budapest.

Gogâltan, F., Savu, M., Kelemen, I. 2015, Mâni magice? Un complex apartinând bronzului Târziu de la Vlaha-Pad (jud. Cluj), Terra Sebus, Acta Musei Sabesiensis, Vol. 7, 73-122.

Grömer, K. 2016, The Art of Pehistoric Textile Making. The Development of Craft Traditions and Clothing in Central Europe, Natural History Museum Vienna, Vienna.

Guštin, M., Tiefengraber, G., Pavlovič, D., Zorko, M. 2017, Nova Tabla pri Murski Soboti, Arheologija na avtocestah Slovenije, Vol. 52/1, Ljubljana.

Heilmann, D. 2016, Contextualising Bow Fibulae with Boeotian Shield Plates: Cultural Transfer Processes during Early Iron Age in the Central Balkan Area, Starinar, Vol. 66, 9-26.

Hodson, F. R. 1990, Hallstatt The Ramsauer Graves. Quantification and Analysis, Dr. Rudolf Habelt $\mathrm{GmbH}$, Bonn.
Hoffiller, V. 1938, Dalj, Corpus Vasorum Antiquorum, Fasc. 2, Beograd.

Hršak, T., Leleković, T., Dizdar, M. 2013, Rezultati istraživanja nalazišta Batina - Sredno 2012. godine, Annales Instituti Archaeologici, Vol. IX, 12-19.

Hršak, T., Leleković, T., Dizdar, M. 2014, Rezultati istraživanja nalazišta Batina - Sredno 2013. godine, Annales Instituti Archaeologici, Vol. X, 14-20.

Hršak, T., Leleković, T., Dizdar, M. 2015, Rezultati istraživanja nalazišta Batina - Sredno 2014. godine, Annales Instituti Archaeologici, Vol. $\mathrm{XI}, 18-22$.

Hršak, T., Leleković, T., Dizdar, M. 2016, Rezultati istraživanja nalazišta Batina - Sredno 2015. godine, Annales Instituti Archaeologici, Vol. XII, 14-18.

Hršak, T., Leleković, T., Dizdar, M. 2017, Rezultati istraživanja nalazišta Batina - Sredno 2016. godine, Annales Instituti Archaeologici, Vol. XIII, 40-45.

Kossack, G. 1954, Studien zum Symbolgut der Urnenfelder- und Hallstattzeit Mitteleuropas, Römisch-Germanischen Forschungen, Band 20, Verlag von Walter de Gruyter \& CO, Berlin.

Kunter, K. 1995, Schichtaugenperlen, Glasperlen der vorrömischen Eisenzeit IV, Marburger Studien zur Vor- und Frühgeschichte, Band 18, Vorgeschichtliches Seminar Marburg, Espelkamp.

Ložnjak Dizdar, D. 2010, Sotinska groblja u željeznom dobu, in: Arheološke spoznaje o Sotinu. Rezultati probnih istraživanja 2008.-2010., Hutinec M., Ložnjak Dizdar D. (eds.), Gradski muzej Vukovar, Vukovar, 24-28.

Ložnjak Dizdar, D. 2011, Funerary Practices of Late Bronze Age Communities in Continental Croatia, in: Bronze Age Rites and Rituals in the Carpathian Basin, Berecki S., Nemeth R. E., Rezi B. (eds.), Proceedings of the International Colloquium from Targu Mureş 2010, Bibliotheca Musei Marisiensis, Seria Archaeologica IV, Editura Mega, Târgu Mureş, 245-259.

Ložnjak Dizdar, D. 2015, Slatina/Berezine - Early Iron Age graves in Central Podravina, in: Beiträge zur Hallstattzeit am Rande der Südostalpen, Akten des 2. Internationalen Symposiums am 10. und 11. Juni 2010 in Wildon (Steiermark/Österreich), Gutjahr Ch., Tiefengraber G. (eds.), Maria Leidorf Verlag GmbH, Rahden/Westf., 29-43.

Ložnjak Dizdar, D., Rajić Šikanjić, P. 2016, Funerary Practices at the End of the Late Bronze Age in the southern Middle Danube Region, in: Funerary Practices during the Bronze and Iron Ages in Central and southeast Europe, Sîrbu V., Jevtić M., Dmitrović K., Ljuština M. (eds.), Proceedings of the $14^{\text {th }}$ International Colloquium of Funerary Archaeology in Čačak, Serbia, $24^{\text {th }}-27^{\text {th }}$ September 2015, Beograd-Čačak, 109-126.

Metzner-Nebelsick, C. 1996, Die Urnenfelder- und Hallstattzeit in Südostpannonien - eine Region im Spannungsfeld zwischen Osthallstattkreis, karpatenländisch-balkanischer Eisenzeit und Steppenkultur, in: Die Osthallstattkultur, Akten des Internationalen Symposiums, Sopron 1994, Jerem E., Meid W. (eds.), Archaeolingua Band 7, Budapest, 283-314.

Metzner-Nebelsick, C. 1997a, Hallstattzeitliche Zentren in Südostpannonien, Zalai Múzeum, Vol. 8, 9-26.

Metzner-Nebelsick, C. 1997b, Tönerne Stecker - "magische" Gegenstände? Ein Beitrag zum keramischen Symbolgut der Urnenfelder-

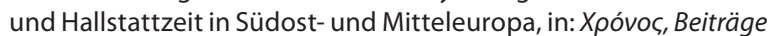
zur Prähistorischen Archäologie zwischen Nord- und Südosteuropa, Festschrift für Bernhard Hänsel, Becker C., Dunkelmann M.-L., Metzner-Nebelsick C., Peter-Röcher H., Roeder M., Teržan B. (eds.), Internationale Archäologie, Studia honoraria Band 7, Verlag Marie Leidorf GmbH, Espelkamp, 577-599.

Metzner-Nebelsick, C. 2002, Der «Thrako-Kimmerische» Formenkreis aus der Sicht der Urnenfelder- und Hallstattzeit im südöstlichen Pannonien, Vorgeschichtliche Forschungen Band 23, Verlag Marie Leidorf $\mathrm{GmbH}$, Rahden/Westf.

Metzner-Nebelsick, C. 2017a, At the Crossroads of the Hallstatt East, in: Connecting Elites and Regions, Schumann R., Van der VaartVerschoof S. (eds.), Sidestone Press, Leiden, 349-379.

Metzner-Nebelsick, C. 2017b, Sumptuous Vessels and Animal Protomes New finds of the early Hallstatt Period in Southeastern Pannonia, in: Das nördliche Karpatenbecken in der Hallstattzeit. Wirtschaft, Handel und Kommunikation in früheisenzeitlichen Gesellschaften zwischen Ostalpen und Westpannonien, Miroššayová E., Pare Ch., 
Stegmann-Rajtár S. (eds.), Archaeolingua, Budapest, 433-470.

Minichreiter, K. 1976, Batina skela, Općina Beli Manastir - prahistorijski i antički lokalitet, Arheološki Pregled, Vol. 18, 37-40.

Minichreiter, K. 1987, Arheološko blago Baranje, Anali Zavoda za znanstveni rad u Osijeku, Vol. 5 (1986/1987), 43-142.

Nađ, I., Nađ, P. 1964, Katalog Arheolške zbirke dr. Imre Freya, Gradski muzej Sombor, Sombor.

Nebelsick, L. D. 1994, Der Übergang von der Urnenfelder- zur Hallstattzeit am nördlichen Ostalpenrand und im nördlichen Transdanubien, in: Archäologische Untersuchungen zum Übergang von der Bronze- zur Eisenzeit zwischen Nordsee und Kaukasus, Schauer P. (ed.), Regensburger Beiträge zur Prähistorischen Archäologie, Band 1, Regensburg, 307-363.

Nebelsick, L. D. 1997, Die Kalenderberggruppe der Hallstattzeit am Nordostalpenrand, in: Hallstattkultur im osten Österreichs, Nebelsick L. D., Eibner A., Lauermann E., Neugebauer J. W. (eds.), St. Pölten, 9-128.

Nebelsick, L. D. 2016, Drinking against death. Studies on the materiality and iconography of ritual, sacrifice and transcendence in later prehistoric Europe, Wydawnictwo Uniwersytetu Kardynała Stefana Wyszynskiego, Warszawa.

Pare, Ch. F. E. 1999, Beiträge zum Übergang von der Bronze- zur Eisenzeit in Mitteleuropa. Teil I, Grundzüge der Chronologie im östlichen Mitteleuropa (11.-8. Jahrhundert v. Chr.), Jahrbuch des RömischGermanischen Zentralmuseum Mainz, Vol. 45/1 (1998), 293-433.

Patek, E. 1982a, Recent excavations at the Hallstatt and La Tène Hill-fort of Sopron-Várhely (Burgstall) and the predecessors of the Hallstatt culture in Hungary, British Archaeological Reports IS 144, 1-56.

Patek, E. 1982b, Die hallstattzeitlichen Glasperlen Transdanubiens, Savaria, Vol. 16, 161-180.

Patek, E. 1983, Neue Untersuchungen auf dem Burgstall bei Sopron, Bericht der Römisch-Germanischen Kommission, Band 63 (1982), 105-177.

Patek, E. 1993, Westungarn in der Hallstattzeit, Acta humaniora, Weinheim.

Pinterović, D. 1971, Batina - praistorijski i antički nalazi, Arheološki Pregled, Vol. 13, 55-58.

Rebay, K. C. 2002, Die hallstattzeitliche Grabhügelgruppe von Zagersdorf im Burgenland, Wissenschaftliche Arbeiten aus dem Burgenland, Band 107, Eisenstadt.

Říhovský, J. 1983, Die Nadeln in Westungarn I, Prähistorische Bronzefunde, Abteilung XIII, Band 10, München.

Stegmann-Rajtár, S. 1993, Spätbronze- und früheisenzeitliche Fundgruppen des mittleren Donaugebietes, Bericht der Römisch-Ger- manischen Kommission, Band 73 (1992), 29-179.

Szombathy, J. 1924, Die Tumuli im Feichtenboden bei Fischau am Steinfeld, Mitteilungen der Anthropologischen Gesellschaft in Wien, Band LIV, 163-197.

Šimić, J. 2001, Brončano i starije željezno doba na području grada Osijeka, Osječki Zbronik, Vol. XXIV-XXV (1996-1999), 23-42.

Šimić, J. 2002, Zaštitno sondiranje na prapovijesnom nalazištu BatinaGradac, Obavijesti Hrvatskog arheološkog društva, Vol. XXXIV/3, 56-59.

Šimić, J. 2004, Grupa Dalj, in: Ratnici na razmeđu istoka i zapada, Starije željezno doba u kontinentalnoj Hrvatskoj, Balen-Letunić D. (ed.), Katalog izložbe, Zagreb, 36-77.

Tasić, N. 1994, Nekropola kod Doroslova i njen značaj za proučavanje starijeg gvozdenog doba Podunavlja, in: Kulture gvozdenog doba jugoslovenskog Podunavlja, Balkanološki institut SANU, Posebna izdanja 55, Tasić N. (ed.), Beograd, 9-19.

Teržan, B. 1990, Starejša železna doba na Slovenskem Štajerskem, Katalozi in Monografije 25, Ljubljana.

Tomedi, G. 2002, Das hallstattzeitliche Gräberfeld von Frög, Die Altgrabungen von 1883 bis 1892, Archaeolingua Band 14, Budapest.

Trajković, D. 2008, Đepfeld - Nekropola starijeg gvozdenog doba kod Doroslova, Gradski muzej Sombor, Sombor.

Vasić, R. 1996, Quelques considèrations sur le terme „Basarabi, in: Der Basarabi Komplex in Mittel- und Südosteuropa, Roman P. (ed.), Kolloquium in Drobeta-Turnu Severin (7.-9. November 1996), Rumänisch-Jugoslawische Kommission für die Erforschung der Region des Eisernen Tores, Archäologische Abteilung I, Bukarest, $15-21$.

Vasić, R. 2003, Die Nadeln im Zentralbalkan, Prähistorische Bronzefunde, Abteilung XIII, Band 11, Stuttgart.

Vasić, R. 2008, Doroslovo, in: D. Trajković, Đepfeld - Nekropola starijeg gvozdenog doba kod Doroslova, Gradski muzej Sombor, Sombor, 337-354.

Vinski, Z., Vinski-Gasparini, K. 1962, O utjecajima istočno-alpske halštatske kulture i balkanske ilirske kulture na slavonsko-sremsko Podunavlje, Arheološki radovi i rasprave, Vol. II, 263-293.

Vinski-Gasparini, K. 1973, Kultura polja sa žarama u sjevernoj Hrvatskoj, Monografije Vol. 1, Zadar.

Vinski-Gasparini, K. 1978, Osvrt na istraživanja kasnog brončanog i starijeg željeznog doba u sjevernoj Hrvatskoj, Izdanja Hrvatskog arheološkog društva, Vol. 2, 129-148.

Vinski-Gasparini, K. 1983, Kultura polja sa žarama sa svojim grupama, in: Praistorija jugoslavenskih zemalja IV: Bronzano doba, Čović B. (ed.), Sarajevo, 547-667. 
ZVONKO BOJČIĆ ET AL., NEW KNOWLEDGE ABOUT THE CHRONOLOGY OF THE BATINA - SREDNO CEMETERY AT THE BEGINNING OF THE EARLY ..., PRIL. INST. ARHEOL. ZAGREBU, 35/2018, P. 159-192

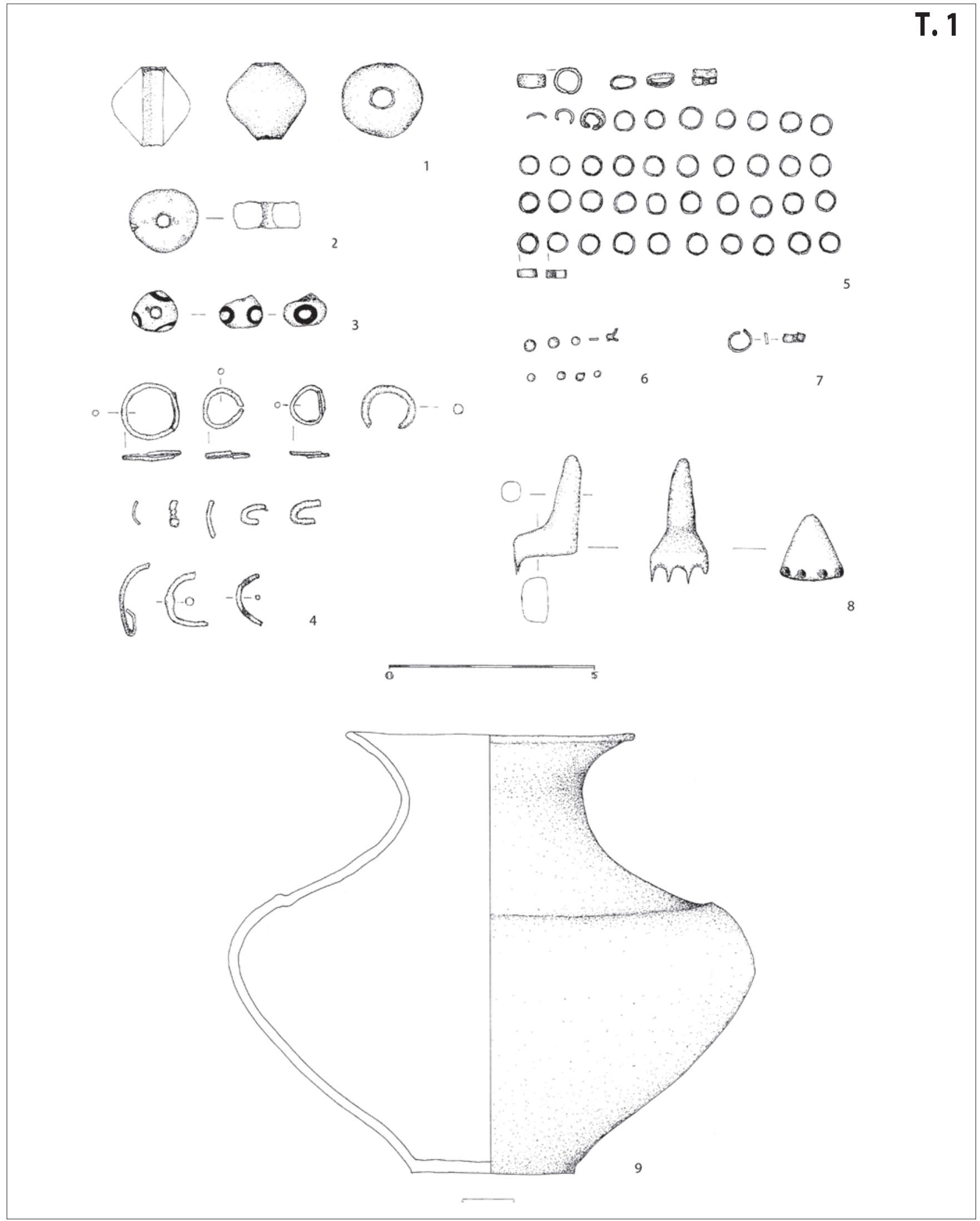

T. 1 Grob 36 (crtež: M. Rončević, D. Radman) Pl. 1 Grave 36 (drawing: M. Rončević, D. Radman)

189 


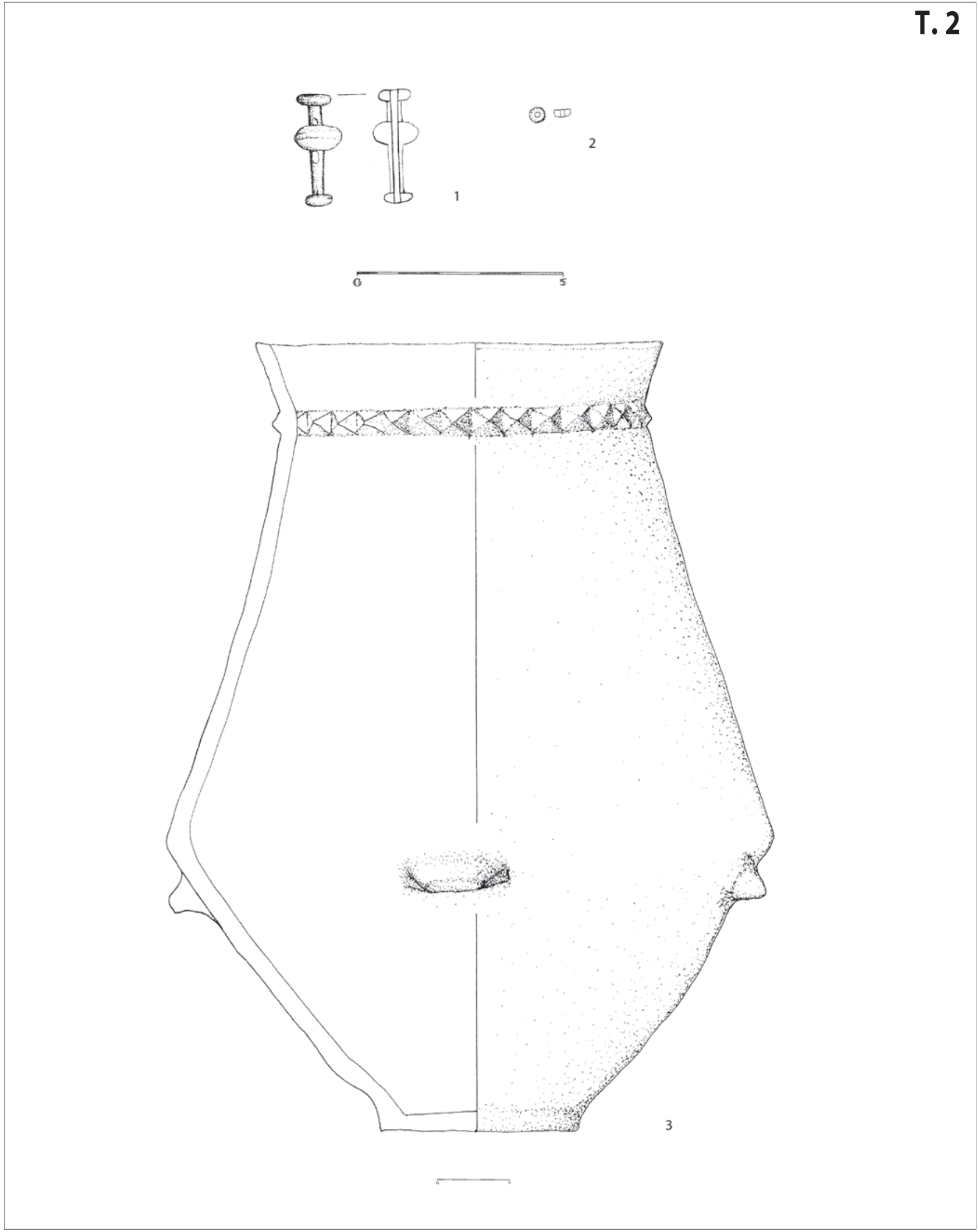

T. 2 Grob 37 (crtež: D. Radman)

Pl. 2 Grave 37 (drawing:D. Radman) 

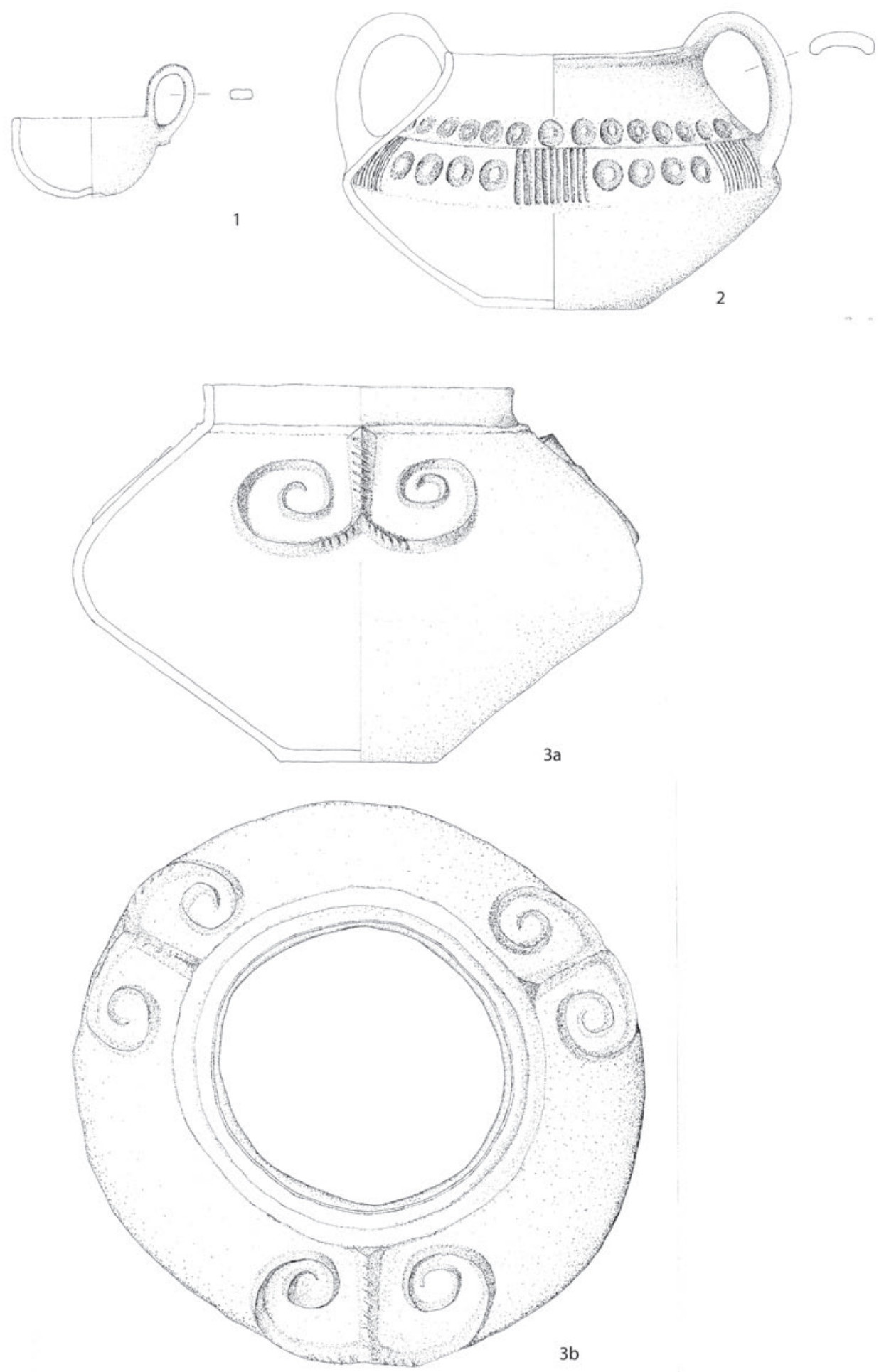

T. 3 Grob 37 (crtež: D. Radman)

PI. 3 Grave 37 (drawing:D. Radman) 


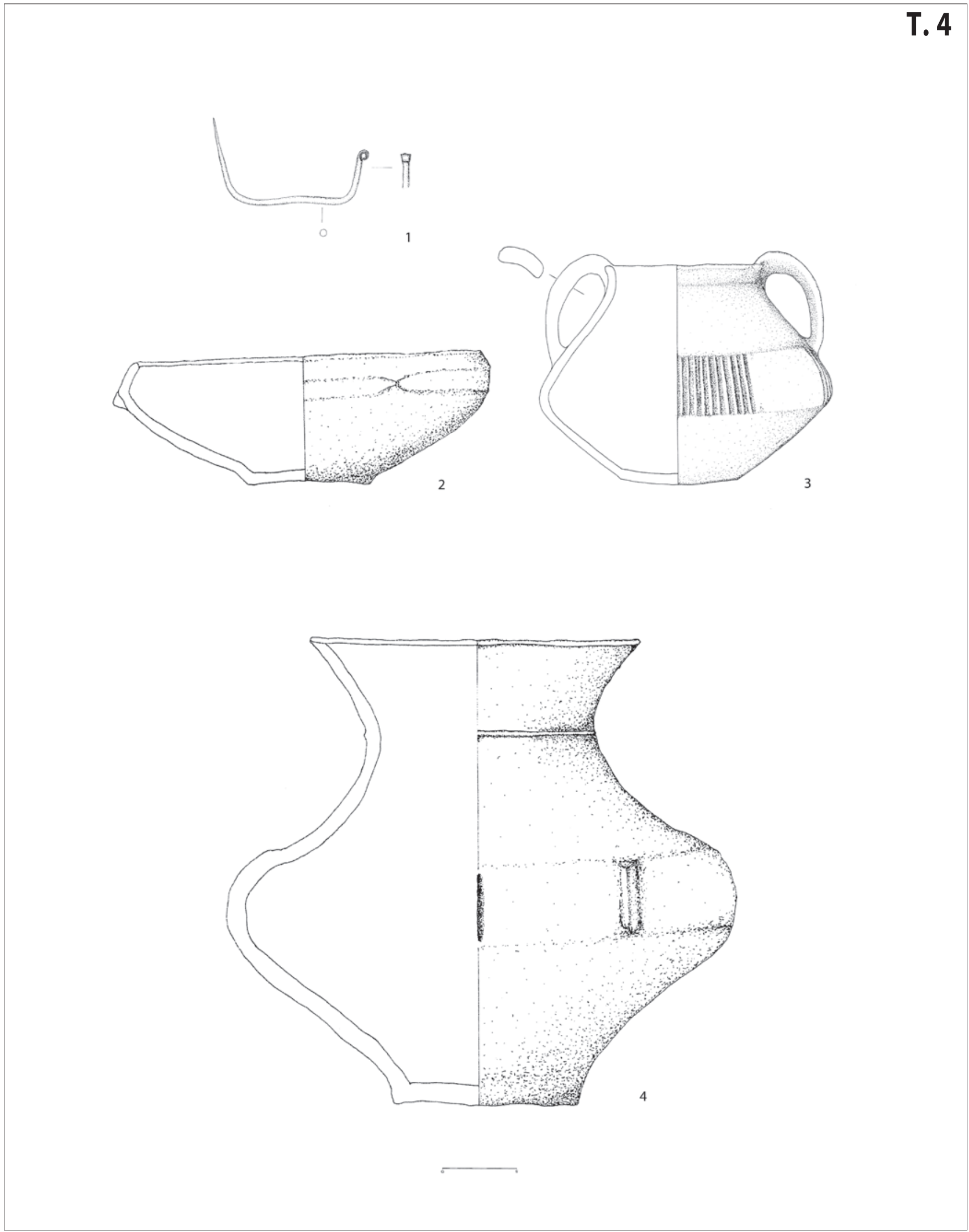

T. 4 Grob 38 (crtež: D. Radman)

PI. 4 Grave 38 (drawning:D. Radman) 